


)

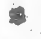

b. of

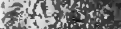

i. An

(3) ton $4_{-2}^{10} \div 3$ $x^{2}+x^{2}$

* - 3trth $+2 y=-3 i=$ -7. 31

a $\because 4$ ? $x^{2}$

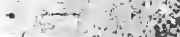

$\sum_{3}=$

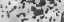

1. $\therefore \quad \therefore-4=$

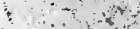
$15=$

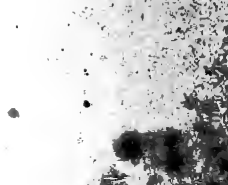

the

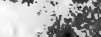

(5)

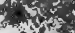

$i^{2}+30$

4 i

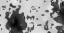

$x_{x \rightarrow 4}+2$

4 है

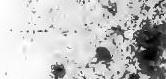

$\therefore \quad+x^{2}$

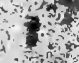

$i n-7$

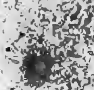

$\therefore \therefore$

4

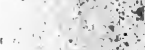

$=-2$ 


\section{TRACTS FOR THE TIMES.}

\section{ON THE MYSTICISM ATTRIBUTED TO THE EARLY FATHERS OF THE CHURCH.}

\section{\$ i.-Occasion, Grounds, and Limits of the Present Inquiry.}

(1.) Ir is curious, and may be not uninstructive, to observe how §i. 1. from time to time the assailants of Primitive Antiquity have shifted their ground, since the beginning of the seventeenth century. During the struggle of the Reformation, men had felt instinctively, if they did not clearly see, that the Fathers were against them, so far as they had begun to rationalize, whether in ecclesiastical practice, or in theological inquiry. But it was many years before they ventured to avow this feeling distinctly to themselves, much more to maintain and propagate it. It was not until divines of his class had thoroughly wearied themselves in vain endeavours to reconcile the three first centuries with Calvin and Zuinglius, that Daille published his celebrated treatise "Of the Right Use of the Fathers ${ }^{1}: "$ in which, under pretence of impugning their suffciency as judges between Papist and Protestant, he has dexterously insinuated every topic most likely to impair their general credit; professing all the while extreme respect both for their sanctity and their wisdom; although, perhaps, an attentive reader may perceive his ironical meaning, disclosing itself more and more, as his argument draws to a point. However, by his skill in rhetorical arrangement, and by a certain air of thorough command of his subject, which he has been very successful in assuming, he became at once the stanclard author for all who took that side of the question; opening (if so homely a simile may be allowed) a kind

${ }^{1}$ In 1631.

YoL. vi. -89 . 
$\S$ i. 1. of cheap shop, to which all who had a fancy for wares of that kind have ever since found it convenient to resort.

But though at the bottom Daille seems to have had no more respect for Antiquity than those who came after him, he differs from them greatly, not only in his tone and manner, but also in the very ground and substance of his argument : professing, first, to confine himself to those points which are disputed between the Reformed and the Roman Church, (and, therefore, not to except against the Fathers' evidence on matters debated in their times, e.g. on the Trinitarian Controversy ;) and secondly, laying, or seeming to lay, the chief stress of his objections on the scantiness of their remains, the amount of corruption and interpolation, the difficulty of ascertaining their real sense, and the like. When he does proceed to challenge their authority, he is careful in pointing out their own disclaimers of such authority, before he exemplifies their supposed errors and inconsistencies; which he does largely, but with great show of unwillingness, in the concluding sections of his work.

But now, if we pass over a hundred years, and come to the attacks made on the Fathers in the beginning of the eighteenth century, we shall find, for the most part, the same quotations appealed to, the same particulars insisted on, but with an air of much more open defiance, and with the direct and avowed purpose of impugning their credit, not in this or that point only, but in all questions of Christian religion. Thus Whitby prefaces his collection of what he calls specimens of patristical exposition of Scripture, with a declaration ${ }^{1}$, that he wishes to exclude appeals to Antiquity, as to the transmission of the Rule of Faith, (meaning the great fundamental doctrines,) no less than in facts of general history, or in the controversies between England and Rome. And Middleton, in his flippant "Free Inquiry," lays the stress of his argument on his being able to prove that the ancient Fathers "were of a character from which nothing could be expected but what a weak or crafty understanding could supply, towards confirming those prejudices with which they happened to be possessed, especially where religion was the subject ${ }^{2}$."

' Pref. § 2. ed. $1714 . \quad 2$ Pref. p. xxxii. 
One would think it impossible to go beyond this in the way of disparagement; but so it is, that in the course of the century which has elapsed since Whitby and Middleton, a yet more disrespectful, because more summary, way of dealing with the Fathers has become current. Whitby and Middleton did think it necessary to appear to have examined what is really to be found in Antiquity; and the former especially exhibits, throughout his treatise above-mentioned, what on his principles must be called a morbid anxiety, to confirm his own views. on several important subjects, (on original sin, for example, and the natural condition of infants,) by the testimony of the very writers, whom he is most busy in disparaging. But in our day, perhaps, the more usual course is, for persons, who do not even profess any acquaintance with those writers, beyond vague impressions received from report or quotation, to dispose of their authority in any controverted point, under the notion, understood or expressed, that " the Fathers were Mystics, and need not be regarded at all."

(2.) Now, if it were indeed an object with the Evil Spirit, to decry the relics of Christian Antiquity, and divert men's attention from them, it is difficult to say what single word he could have chosen, so critically adapted to his purpose in our days, as this same word, Mysticism. In the first place, it is not a hard word, having been customarily applied to such writers as Fenelon and William Law, whom all parties have generally agreed to praise and admire. So far it suits well with the smoothness of phrase, on which the present generation especially prides itself. It seems to set down the Fathers gently, and so is readily acquiesced in by many, who would shrink from the coarse sneers of Middleton or Gibbon.

In the next place, it touches the very string, which most certainly moves contemptuous thought, in those who have imbibed the peculiar spirit of our time. Mysticism, implies a sort of confusion between physical and moral, visible and spiritual agency, most abhorrent to the minds of those, who pique themselves on having thoroughly clear ideas, and on their power of distinctly analysing effects into their proper causes, whether in matter or in mind. 
§i. 3. Again, Mysticism conveys the notion of something essentially and altogether remote from common sense and practical utility: but common sense and practical utility are the very idols of this age.

Further, that which is stigmatized as Mysticism, is almost always something which at once makes itself discerned by internal evidence. The man of the world, the practical man, the inductive experimental philosopher, commonly persuades himself that le can perceive by instinct, when a train of thought, or mode of speaking, is mere religious dreaming, indistinct fanciful theory; and he rejects it accordingly, and is saved all trouble of research. Here, again, is no small temptation, in the eyes of a world full of hurry and business, to acquiesce over lightly in any censure of that kind.

Yet, again, if any man be disposed to speak and think more harshly of the early Christian writers, this same term, Mysticism, may serve his purpose also ; for it is easy, by a dexterous enunciation, or choice of context, to insinuate through it a charge of deliberate fraud. It is an instance, therefore, of a mode of speaking, equally convenient for all shades and degrees of enmity to, or contempt of, Antiquity. We see what its power is in a kindred instance; how meanly even respectable persons allow themselves to think of the highest sort of poetry, - that which invests all things, great and small, with the noblest of all associations, - when once they have come to annex to it the notion of Mysticism. And perhaps its mischievous effects on theology are as great as any attributable to a single word.

(3.) It may, therefore, be of some use to consider, as distinctly as we can, what people really mean when they charge the Fathers with Mysticism ; which being done, we may perhaps have a better chance of making out to our satisfaction, whether, and how far, as a body, they diserve the charge.

By the term Mysticism, then, as applied to the writers in question, I understand to be denoted, a disposition, first, to regard things as supernatural which are not really such; and secondly, to press and strain what may perhaps be really supernatural in an undue and extravagant way. 
(4.) Upon which bare statement, without going any further, a §i. 4. devout mind will probably at once acknowledge, on which side in the present question the peril of erring will be greatest. The question is like that of the general evidences of religion: a person who would go into it with advantage, should be imbued beforehand with a kind of natural piety, which will cause him to remember all along, that perhaps, when he comes to the end of his inquiry, he will find that GoD was all the while really there. He will "put off his shoes from off his feet," if he do but think it possible that an angel may tell him, by and by, "The place where thou standest is holy ground." So it must be, in some measure, with every right-minded person, in the examination of every practice and opinion, against which the charge of Mysticism is brought. Whatever may appear in the case at first sight, likely to move scorn or ridicule, or tempt to mere lightness of thought; it will be an exercise of faith, a trial of a serious heart, to repress for the time any tendency of that kind: the loss and error being infinitely greater, if we are found trifling with a really sacred subject, than if we merely prove to have been a little more serious than was necessary. In this sense, that is to say in regard of the reverent or irreverent temper, in which such inquiries may be approached, superstition is surely a great deal better than irreligion: whatever may be thought of the abstract question, Whether it be the safer extreme to believe too much, or too little?

It may be said, that the Fathers themselves indicate an exception to this rule, by the light and sarcastic way, in which they often allow themselves to treat the pretended mysteries, sometimes of heathens, sometimes of heretics as bad as heathens. But the case is not strictly in point. For $I$ am speaking of pretensions unexamined, and therefore, as yet, more or less doubtful : but the Fathers had, or accounted themselves to have, good grounds for believing that the mysteries and miracles which they held up to scorn were, in part at least, the work of evil spirits, with whom they thus most effectually renounced communion. Before we indulge the like feeling in our treatment of any claim to supernatural powers, we had need have the like assurance of diabolical agency in them : and that to show them any reverence would seem. 
\$ i. 5. like imparting of God's honour to the Evil One. Although even in such a case deep fear and humiliation of heart would seem the more appropriate sentiment for ordinary Christians. For is it not a fearful and humbling thonght, that mankind, that we ourselves, are, or have been, in danger of mistaking the work of God's enemy for His own?

Further, it may be well to bear in mind, that the noblest and most refined devotional tendencies have always had to bear the imputation of Mysticism, or some other equivalènt word; as if to cultivate them were a mere indulgence of a dreamy, soaring, indistinct fancy. In this use of it, the word Mysticism has done probably as much harm in checking high contemplative devotion, as the kindred term, Asceticism, in discouraging Christian selfdiscipline.

Thus much for the first impression, which the very application of the term to the Fathers would make on a considerate person, as yet ignorant of their writings. He would expect, almost certainly, to find them imbued with devotional feelings of an unusually high order ; and he would be prepared for the possibility, that even those views of theirs, which might seem at first glance overstrained, fantastic, or unnatural, might turn out in the end to be portions of true Christian wisdom.

(5.) What now are the particulars of the Fathers' imputed Mysticism ? i. e. in what respects would they be commonly charged with an undue anxiety to make out supernatural meanings and interferences? The following heads would seem to comprehend the greater part of their supposed delinquencies in this kind:-

1. Their interpretations of Scripture are said to be far-fetched and extravagant ; extracting figurative, theological allusions out of the most irrelevant or insignificant details of language or history.

2. Correspondent to this is their mode of treating natural objects, and the truths of philosophy and common life; fancying every where indications of that system, on which their own hearts were set.

3. They were mystics in their notions of providential interference, whether in the way of judgment, deliverance, or warning. To which head may be referred whatever they state of the exercise of the gift of prophecy in their times; as also their. 
accounts of reputed miracles, and of the sensible agency of evil spirits, and of their own and others' warfare with them.

4. Finally, they are blamed for Mysticism, properly so called, in their moral and devotional rules; i. e. for dwelling too much on counsels of perfection, tending (as is affirmed) to contemplation rather than action, to monastic rather than social and practical virtue.

These are the sort of imputations on which the changes have been rung, for the two last centuries, by those who have wished to evade the testimony of the Fathers, without setting them down distinctly as deliberate impostors.

(6.) It may be added, that many of their professed advocates, (Warburton for example,) have in fact given up their cause, as far as concerns every one of these representations. For what, in reality, does his defence of them come to, even when he is led to state their case most favourably; e. g. in the Preface to Julian? Just to this, and no more : that they might be trusted in their relations of things which came within the scope of their own knowledge, provided there was no room for surmising any thing miraculous : and again, that on other subjects, whether as reasoners or as narrators, they were not weaker, but a little wiser, than Pagan and Jewish writers of the same date.

It is true that Warburton belonged to a school, which has a temptation of its own for slighting the Fathers, over and above differences in particular doctrines; a school, whose leading principle is, that theology, like other sciences, improves by time: or, (to use the words of one of its most plausible advocates) that "Christianity was in its infancy, at most in its childhood, when these men wrote; and therefore it is no wonder that they spake as children, that they understood as children, that they thought as children. This was according to the economy they were then under ${ }^{1}$."

Such writers, when they speak most modestly of themselves, and most respectfully of antiquity, do not however hesitate to make use of the oid simile, of a dwarf seeing further than a giant when raised on a giant's shoulders ; imagining it to be as applicable

1 Bishop Law, as quoted by Middleton, p. 57. 
$\S$ i. 7. to religion, as it is to physical and human learning; and, when they would most appear to advocate the ancients, cannot of course refrain from stigmatizing them as inadequate judges of Christian truth, infected sometimes with Platonic, sometimes with Rabbinical error : and thus, while with a sort of candour they excuse the men at the expense of the age, they do the Adversary's work, by detracting from their authority, and withdrawing attention and deference from their writings.

But even those who in their hearts really loved to lean on Antiquity, and would have been uneasy, if they had not the suffrage of the Fathers with them, have not always taken the course most likely to win them due respect. Whether it were that they feared to commit themselves,-or that they shrunk before popular notions,-or as a mere matter of taste and feeling,- the champions of the Fathers, for many years past, have generally been content to claim credit for them only as witnesses to certain palpable facts of their time : the inevitable consequence of which has been, that even diligent and earnest inquirers have been satisfied with a second-hand knowledge of their writings; and often, when they have come in to fill their proper place in argumentative discussions, they have nevertheless been far from occupying the room which justly belonged to them, in our theological views and impressions. There are, and have been, praiseworthy attempts to raise their credit, by drawing attention to those portions of their literature, which seemed to have most in common with modern ideas, whether in the way of general reasoning with unbelievers, or of refined devotional feeling, or of eloquent morality. But the very circumstance of such selections being made with a view to modern prejudices, shows that they can do no more than palliate the evil. When a reader passes from specimens of that kind to the whole body of any Father's writings, he is apt to feel as if he had been unfairly dealt with, and is inclined rather to be the more intolerant of the many things which he is sure to meet with, alien to his former tastes and habits of thought.

(7.) May it not with reason be suspected, that the root of the matter lies deeper, and that in order to arrive at it, we must make up our minds thoroughly to consider the whole subject 
$a b$ initio? It may perhaps turn out that the boldest way of meeting the difficulty is the most rational, and ultimately the most consoling. We must not be startled, though we find ourselves compelled to own, that modern and ancient theology are to a great extent irreconcileable; that if popular notions are right, the Fathers are indeed "mystical" in a bad sense, and that, in all the several departments above mentioned.

Thus, in respect, first, of Scripture interprctation, the received doctrine of this age seems to be, that nothing ought to be figuratively or typically explained, except on the authority of Scripture itself ${ }^{1}$; it being assumed, that we can no otherwise be certified of the divinely intended relation, necessary to make up the nature of a real Type. Now those who hold this rule must necessarily think meanly of the Fathers as expounders of Scripture, since in every paragraph almost we find some allegory, not scriptural according to the required test.

Secondly, in respect of allusions moral or theological, regularly and uniformly deduced from the contemplation of the creatures of God, in the manner, e. g. of Boyle's Occasional Reflections ; it would probably be considered a candid judgment, in our time, which should allow that such might constitute tolerable poetry: but to consider them as a part of theology, to regard them as having been from the beginning intended by the Creator, and the creation ordered with a view to them;-who is there among us, that would not at first be tempted to reject such a theory as overstrained and merely fanciful?

Thirdly, consider the tone of thought, which is accounted safest and meets with most encouragement in our days, concerning the intimations of GoD's mysterious providence, whether national or individual. Is it not a subject, that, as things are, even sincere-minded persons shrink from? They are afraid of trusting themselves with it, though but in thought. What is meant will be perceived in a moment, if people will reflect what their first impressions were, on reading, e.g., the Journal of Archbishop Laud,

1 Bp. Van Mildert, B. L. 239, ap. Horne, Introd. ii. 724 ; Macknight, on St Paul's Ep. iv. 439. 
$\S$ i. 8. those portions of it which detail supposed providential warnings. Or, again, how backward we all find ourselves in confessing our sense of God's judgments, public and private, when in our thoughts we can hardly fail to perceive them. I am far from asserting that this backwardness is not both pious and reasonable, taking all circumstances into account: but does it not imply a great change, either in men's condition or opinions, or in both, since the days of St. Ignatius and St. Cyprian?

Lastly, the difference in moral sentiments is too obvious to be denied. The cheerful, liberal, indulgent side is the popular one, now, in all questions of ethics : severity, strictness, self-denial, are but so far approved, as their immediate good effect is seen and understood. Need it be remarked, that the direct contrary is the case of the Primitive Church?

On the whole, the discrepancies between the two ages, occasioning the imputation of Mysticism to the ancients, are far beyond being accounted for by local, accidental, or temporary circumstances; they must be referred to some difference in first principles: and unless we are prepared to say positively, with the philosophic theologians above mentioned, that theology is, like other sciences, really advancing, of course, as the world grows older; we cannot but in candour allow it at least possible, before examination, that the ancients may have been in the right, and we in the wrong.

(8.) In order to judge of this fairly, one should begin by stating, with its due limitations, the real judgment of Christian Antiquity on the several matters above enumerated,-an undertaking evidently far beyond the limits of such an essay as the present : one can only endeavour to give some faint specimen of the results, which, it is conceived, more extensive inquiry would establish; premising, however, the following cautions, as necessary to be kept in view throughout the inquiry.

First, that since we are to speak of the Fathers collectively, we must be careful to select those points, in which they exhibit a tolerably general agreement. This limitation disposes at once of many of the most plausible objections to the views of Antiquity, and also of many of the unworthy and inadequate allegations of 
its timid defenders ; as I hope to show hereafter in some import§i. 8. ant examples.

But to make the rule a practical one, we should well understand, secondly, what is to be accounted general agreement among the Fathers. For it is the third particular in the rule of Vincentius, Quod ab omnibus, which has ever afforded most scope for cavil to the rationalist, and for perplexity to the unwary. But let us only apply to this matter the same rules of common sense, which guide us on analogous subjects in ordinary life. A person not regularly trained in medicine desires to know what are safe rules of diet: is he to believe that there are no such rules at all, because he finds none from which, at some time or other, ingenious innovators have not contrived to dissent? Another wishes to ascertain some point of common law : does he think it necessary for that purpose, that cases in all points exactly like his own shall have come under the cognisance of each former generation of jurists? Or, in matters of navigation, would it be said there were no fixed rules, because but a few out of many seamen have left the results of their experience any where on record? The question about the Fathers is so far like these, that it is strictly a question of practice : men want to know which is the safest way in regard of their duty towards GoD; if they require in every point absolute inevitable demonstration, of course they cannot have it in the Fathers: but do they really think they find it in Holy Scripture?

Certainly many of the principles most relied on by Daille and other such writers, are such that, if we followed them out, we should not stop short of universal scepticism. $E$. $g$. Whitby lays it down as an axiom ', That if Scripture be a perfect rule of faith, it must be so clear in necessary things as to require no interpreter; and that it cannot be a rule or measure where it is obscure. Might he not as reasonably have said, that it cannot be a rule to any one who does not thoroughly understand the languages in which it was originally written? Such sentiments are, in fact, inconsistent with the present condition of man: they deal with us as though we might be independent of human testimony, or arrive at mathematical certainty in moral matters. We can only 
§i. 8. be safe by putting them aside, and resolving to use, on this subject, the same kind of intuitive good sense, which is given us for our guide in all other matters of conduct; which good sense, as even heathen moralists could discern, is the ordinary accompaniment and providential reward of intellectual fairness and purity.

Nor can any measure of general agreement be laid down, in words so precise, as not to leave a great deal to the exercise of this practical wisdom. However, one obvious rule would be, not to demand coincidence in detail, but in general principles ; and again, in those generals only, which belong to the professed subject-matter and scope of the writers. For example, there is hardly one of the Fathers, of whose works we have any corisiderable quantity remaining, but has left on record his interpretation of one part or another of the Old Testament, in sufficient quantity to indicate his rules of exposition. Now, who will deny that it would be a very remarkable fact, should those rules be found, on the whole, the same throughout the whole series of Cathol:c Fathers ; - a fact on which important conclusions may depend? and yet it may so happen, that no one passage in the Bible is quoted by them all; and again, that there are no two of them, who agree in their explanations of all the passages they quote.

Again; it may be, that in the detail of some historical facts, or in some abstract principles not immediately bearing on theology, there may exist a general, not to say an universal, agreement, on which, nevertheless, very little can be built, because on such things they may very well be supposed to have taken for granted what was generally received in their age. Or, if they differ, such difference rather illustrates their concurrence on the great ecclesiastical subjects; for it proves the activity of their minds, and their energy in judging for themselves, where religion permitted.

For example, among the opinions attributed to the Fathers as erroneous, we find ${ }^{1}$ the notion of the soul in its separate state having

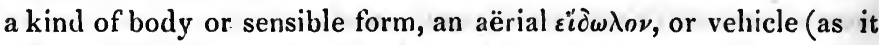
has sometimes been called). And again, we find cited $^{2}$, as a specimen of the discrepancies of Catholic writers, the opposite con-

1 Whitby, pp. 201-3.

2 Ibid. Pref. lxxvi-lxxvii $i$. 
jectures of St. Augustin and St. Jerome on the origination of the $\$$ i. 9, 10. soul. Now, these are metaphysical not theological points; they fall not within the province of Christian Antiquity as such; on such points, neither discrepancy nor agreement in error proves any thing against the Fathers, as Divines.

(9.) As then common sense teaches, that in judging collectively of that large and miscellaneous body of literature, which goes under the name of the Fathers, we must select those points, if any, which are common to the whole mass; and again, that when we speak of agreement among them, we must mean agreement in principle not in detail, and on Christian not on secular subjects : so a little ecclesiastical knowledge will suggest to us another consideration, very needful to be borne in mind, when we are estimating the value of their concurrence in any point within their sphere,-I mean the reverential reserve, which undoubtedly they practised in every part of religion, in proportion to its sacredness. If we would deal fairly with the subject, we must make allowance for this reserve. Knowing for certain that it did exist, we are bound to take it into the account, and often to give those who wrote under its influence credit for a more thorough agreement in high and mysterious doctrines, than their words at first sight would otherwise appear to express. One very remarkable instance, which it-is enough just to mention now, it having been of late amply illustrated, is the doctrine of the Ante-Nicene Fathers concerning the Divinity of the Son of God. Another is, the rule of solemnization of the holy Sacraments. A reader, versed in liturgical language, will often discover in the writings of the Fathers, sometimes in Scripture itself, allusions to the sacraments conveyed in one word or syllable, -allusions prima facie so faint, that we could hardly dare to reason upon them, were we not aware of the duty of reserve which would hinder the writers from more express disclosure of the particulars of those Holy Mysteries.

(10.) It may be well to add one more caution, relating particularly to the interpretation of Scripture. Like all questions of language, especially poetical language, it is to every one of us in some degree a matter of tasle: we come to it prepossessed with certain conventional rules, or certain associations of our own, whicb 


\section{Prejudices of Taste.-Universality of ancient Mysticism.}

§ii. 1. cling by us in spite of ourselves, and often affect our reasonings more than we are aware. But as the Scripture itself, both in substance and in form, is surely far unlike what mere human wisdom would have anticipated, so it is more than possible, that the true method of interpreting it may conduct us on a very different line, from any which would be pointed out by merely human criticism. It seems reasonable, therefore, and religious, to come to questions of that kind, expecting to meet with many things, which may at first seem strange or fanciful, or otherwise unworthy of Divine wisdom; to make up our minds beforehand, that we will not be too much startled by such things, nor reject them at once, but try them by their proper measures; lest we be found deferring to our own prejudices, rather than to the truth of GoD :-prejudices, not so much of opinion, as of rhetorical or poetical taste.

Under such impressions, we may safely approach the first head of Mysticism imputed to the Fathers, viz. their mode of interpreting Holy Scripture.

\section{$\S$ ii.-Specimen of ancient Mysticism in interpreting Scripture.}

(1.) First, as to the matter of fact; we need not perhaps hesitate to admit in the most unreserved way,-indeed it might be hard to find any one who has ever denied,-the universal adoption, by the early Christian writers, of the allegorical way of expounding the Old Testament. They do undoubtedly profess to find an intended figurative and Christian meaning, in innumerable places, which are neither express prophecies, nor alluded to as types in the New. Not only in the prophetical writings do they find our Lord and His Gospel every where; not only do they trace throughout the Levitical services the example and shadow of the future heavenly things; but they deal also in the same way with the records of history, whether Patriarchal or Jewish; and with the fragments which the Holy Grost has caused to be preserved out of the moral and devotional poetry of the Hebrews, - the Book of Job, the Psalms, and the Proverbs, and (what is in some respects the most significant and remarkable instance of all) the Song of Solomon from beginning to end.

The general fact is doubtless familiar to all; being constantly 
produced, on the one hand, by the assailants of the Fathers$\S$ ii. $2,3$. (for "whole books," as Middleton contemptuously says ", "have been compiled of their foolish reasonings in religion;")-nor, on the other hand, has their exercise of this mode of interpretation been ever disputed, as a fact, by their defenders: whether it has been duly appreciated by the writers of either party, is altogether another question. Nowhere, perhaps, among our English divines, will the subject be found treated more thoughtfully or more worthily, than by Bishop Fell, in his notes on St. Cyprian, and on the Apostolical Fathers. However, in so great a consent of witnesses, one may state the case largely without presumption, and without affecting more than a superficial knowledge of Antiquity.

(2.) Let it then be taken for granted, that a mode of expounding, which would seem to most men fanciful and strained, generally prevails in the Christian writers of the first centuries. The great point will be, to account in some measure for this fact. In order to which it may be expedient, not by way of proof but of illustration, if we take some one remarkable instance, and trace it as we may through the writings of some of the most eminent and earliest Fathers. And, not to give them any undue advantage, it may be well to select one of those subjects, their treatment of which is commonly considered most extravagant ; a subject, which has attracted towards them in no common degree the contemptuous wonder of modern critics and philosophers: I mean, their discovering the tokens of our LorD's Passion, and more especially the Sign of the Cross, in innumerable places of the Old Testament, which neither are so expounded in the New, nor to common eyes betray of themselves any such allusion.

(3.) To begin with the Epistle attributed to St. Barnabas ; it is well-known how unreservedly it adopts the allegorical mode of interpietation. Supposing it not to be written by the Apostle,-a supposition which involves no charge of forgery, since it no where professes to be his; and in which it may not be wrong to acquiesce, rather, however, for want of ecclesiastical testimony to its genuineness, than for any thing unworthy of such an origin to be discovered in the epistle itself,-it is undoubtedly, by the man- 
\$ ii. 4. ner in which St. Clement of Alexandria quotes it, a monument of the age next after the A postles, and almost as undoubtedly, judging by internal evidence, it was meant as what in our days would be called a popular hortatory tract, intended to reconcile the Christians of the circumcision to the utter rejection of the Jewish people. And by one expression in it ${ }^{1}$, we may perhaps reasonably assign its date, to the year 136 or thereabouts; when Adrian, having overthrown the rebel Jew's under Bar Cochab, was most active in building Elia on the site of Jerusalem, and a Gentile Christian Church was beginning to flourish there. To this, as it may seem, the author of the Epistle applies the prophecy of Isaiah, (xlix. 17.) according to the reading of the LXX. : " Thou shalt be quickly builded by those who were thy destroyers :' this," says he, "is now in course of accomplishment. For their rising in war led to the subversion of their city by their enemies ; but now the very servants of the same enemies are building it up again."

This date deserves notice, because it suggests a sufficient reason for the freedom with which the author, in a popular tract, exhibits the method of symbolical exposition, which was generally rather withdrawn from ordinary eyes. The calamity, perhaps, was great and astounding enough to justify disclosures otherwise irregular, for the consolation and establishment of the faithful.

However, certain it is that this epistle, which is addressed to Christian men and women without distinction, might be not unfitly selected for a specimen of the mystical way, as applied to the Old 'Testament.

(4.) As concerning the Passion and Cross of our Lord in particular, (to say nothing of the sacrifice of Isaac, the typical nature whereof, as it seems, no age of Christians has ever denied, notwithstanding the silence of Scripture,) St. Barnabas has the following passage ${ }^{2}$ : "Israel being attacked by the aliens, with a view, amongst other things, of signifying to the people, that their transgressions were the cause of their being given over to death, the SPIRIT speaks inwardly to Moses, to f rm a type of the Cross, and of Him who was to suffer: that if men refuse to trust in Him, they will have no peace for ever. Moses therefore places one shield on another in the middle of the mound;
${ }^{1}$ C. xvi.
2 C. xii. 
and being thus posted high above all, he stretches out his hands, §ii. 12. and so Israel began again to be victorious : afterwards, when on the contrary he let down his hands, again they were slaughtered. Wherefore? That men might know there is no chance of salvation, except they put their trust in Him. And in another Prophet he says, "All the day long I have stretched forth my hands to a disobedient and gainsaying people.'"

What is very observable, the Author next goes on to mention, with just the same tone of confidence, and no more, the typical meaning of the Brasen Serpent ; observing, with his usual piety, "Thou hast in this also the glory of JEsus; that in Him, and to Him, are all things."

Had it seemed good to GoD's providence, that the discourse of our Lord to Nicodemus should have been lost, as so many other of His divine words were, would not the Christian interpretation of this latter miracle have seemed to many forced and fanciful, just as that of the former may perhaps seem now? And ought not this single consideration to stop the mouths of all, who have any reverence in their hearts, when they find themselves tempted to join in hasty censure or scorn of such interpretations? For aught they know, they may be scorning or censuring the very lessons of our Divine Master Himself.

(12.) I proceed to another historical type, which to many may appear more extravagant. The Author is reasoning on the history of Abraham, to prove the insufficiency of Jewish circumcision out of the Old Testament itself. So far, as will occur to every one, he is treading in the steps of St. Paul. After producing many passages to that purpose, he closes the subject with the following ${ }^{1}$ : "Consider whether there be not abundant instruction on this whole matter, in the account given us, that Abraham, who first gave men circumcision, did thereby perform a spiritual and typical action, looking forward to the Son : and that, upon receiving certain doctrines conveyed in three (mystical) letters. For He saith, Abraham circumcised of his house men to the number of three hundred and eighteen. What then is 
\$ii. 13. the mysterious truth thus vouchsafed to him? Observe the eighteen first, then the three hundred. Of the two letters which stand for 18,10 is represented by $\mathrm{I}, 8$ by H. Thou hast here the word Jesus :" i. e., the two first letters, which formed as it were a cypher of the sacred Name, familiar to the eyes and thoughts of the Christians of that generation: as was also the third of the numeral letters in question, which the writer next goes on to explain: "Because the Cross, which is signified to the eye by the letter Tau, was intended to bring the grace, [to which he looked forward;] he adds the three hundred also," the letter Tau representing that number. "By the two first letters then the name JEsus is indicated, and by the third the Cross."

On this commentary, which as well as the former has been adopted by multitudes of the early interpreters ${ }^{1}$, several remarks occur, which it may be well to put down, as they will each of them apply to a whole class of examples, and to difficulties which are certain to arise in many of our minds, though we were never so resolutely on our guard against prejudices of mere taste and association.

(13.) First, it may be observed that the several circumstances, which may appear at first sight startling in this exposition, though not perhaps united in any one Scriptural example, have yet, each severally, undoubted sanction of Scripture. Thus, the use of the numeral letters as a cypher, to convey some mysterious truth, has a well-known precedent in the Book of Revelation. Again, the passage in St. Barnabas is an instance of the combination of texts apparently remote, but really bearing on the same subject: for the number, three hundred and eighteen, is not mentioned in the account of the circumcision of Abraham's family, but is borrowed from the previous enumeration occasioned by the war with Chedorlaomer ${ }^{2}$. Now, this sort of combination of remote texts appears to be warranted, in one in-

${ }^{1}$ For example, S. Clem. Alex. Strom. vi. 84; S. Ambr. de Fide, i. init. and $\S 121$; S. Aug. Quæst. in Jud. 37; S. Hil. de Synod. 86.

2 Compare Gen. xvii. 27; xiv. 14. 
stance at least, by our blessed Lord Himself. "Is it not written, - My house shall be called of all nations the house of prayer?" " \$ ii. 14. So far is taken from Isaiah, but the conclusion of the sentence, "Ye have made it a den of thieves," was addressed by Jeremiah to a subsequent generation ${ }^{1}$.

Now whether the fact were really so or not, (if it were, it was surely by special providence, that Abraham's household at the time of circumcision was exactly the same number as before: still the argument of St. Barnabas will stand. As thus : circumcision had from the beginning a reference to our SAviour, as in other respects, so in this; that the mystical number, which is the cypher of JEsus crucified, was the number of the first circumcised household, in the strength of which Abraham prevailed against the powers of the world. So St. Clement of Alexandria ${ }^{2}$, as cited by Fell ": "It is commonly supposed that we have here an indication of a correspondency between the case of Abraham's household and the method of salvation: of the victory obtained by those who have betaken themselves to the Holy Sign and Name, over those who led them captive, and the innumerable tribes of unbelievers, who follow in their train."

(14.) Nor is warrant of Scripture wanting for that which must otherwise seem most inadmissible in this interpretation; the appeal, namely, to the Greek Bible, as having something like divine authority. And this again is a topic which meets us throughout the remains both of the Greek and Latin Fathers. The Septuagint, and Latin versions clearly made from it, are everywhere unscrupulously quoted as the words of inspiration; with the single exception, perhaps, of St. Jerome. Some of the Fathers' opponents would insinuate, that this rests altogether on the tradition reported by Aristeas, of a miraculous consent among the original translators, even in the minutest point. But this is refuted by the language of St. Augustin, who speaks doubtfully of that tradition, but without any doubt of this particular version being so overruled by a prophetic Spirit ${ }^{4}$, that

1 See Isai. lvi. 7 ; Jer. vii. 11.

2 Strom. vi. 11.

3 In loc. S. Barn.

- De Doct. Christ. ii. 22. 
\$ii. 14. even in those places where it swerved from the Hebrew Verity, there was a special providential design in such variation ${ }^{1}$.

Now, can it be denied, that this idea receives countenance from the mode in which the Old Testament is quoted in the New? In the Epistle to the Hebrews, for example, St. Paul argues at large the necessity of the Mediator's death, from the use of the word

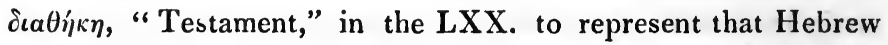
word which is commonly translated Covenant. "For this cause," says he, "it is a New Testament, of which CHrist is said to be Mediator, that by means of death the called might receive the promise; for where a Testament is pleaded, the death of the testator must necessarily be alleged. For a Testament is valid in the case of the dead, since it never avails, as long as the testator is alive 2." And he goes on to show how the word was applicable to the Mosaic covenant also, i. e. by the typical death of the sacrifices. Who does not see that this reasoning is grounded entirely on the Greek version? since the Hebrew ברית does not in any way answer to the notion of a last will. St. Paul's reasoning implies therefore thus much at least concerning the LXX; that in their rendering of this very critical word, they were providentially directed to the use of a term, which should convey an allusion to a great Christian mystery. And so far the Apostle warrants the judgment of St. Augustin ${ }^{3}$ : “Whoever besides shall truly translate any portion of the Old Testament from Hebrew into another language :" (St. Jerome, of course, was in his mind:) " his version will be found either to agree with that of the LXX. or if it appears not to agree, in that very disagreement we must believe that there exists some deep prophetic meaning." Nay, even St. Jerome, when he is impugning their authority, seems to own that there might exist in them a modified and inferior kind of inspiration. "I do" not condemn, I do not blame the LXX. but I confidently prefer the Apostles to them all. Christ speaks to me by the lips of those, concerning whom I read ${ }^{5}$, that they stand even before

${ }^{1}$ De Civ. Dei, xviii. $43 . \quad{ }^{2}$ Heb. ix. 15-20. $\quad{ }^{3}$ S. Aug. ubi sup.

4 Prolog. in Gen. t. ix. p. 10. Ed. Vallars. Venet. 1770.

${ }^{5} 1$ Cor. xii. 28. 
Prophets in the order of spiritual gifts; in which order the inter§ii. 15. pretation of tongues occupies nearly the last place."

We have seen that in one place at least this view is justified by the Scripture: and one place is sufficient for our present purpose, which is, not to prove the LXX. infallible, but to bespeak a certain reverence for their yet unexamined decisions, and for the constant appeals of the early writers to them. For who can assure himself, that in any variation from the Hebrew, which seems to him most unaccountable, they were not guided by the same influence, which caused them to write Testament instead of Covenant, in the places referred to by St. Paul?

(15.) To return to the passage in Genesis : in whatever measure the fact is made out, that the received Greek version of the Scriptures was under a peculiar providence, in the same degree it is rendered not improbable, that even in such an apparently casual thing as the number of Abraham's servants, there was an eye to the benefit and consolation which the Church should long after receive, on recognising, as it were, her Saviour's cypher, in the account of the one holy family triumphantly warring against the powers of the world. It were a most inadequate judgment, to estimate that consolation by any of the feelings and opinions current in our time. We must go back to the days when Christians were used to carry about with them every where the Sign of the Cross; when, to use the forcible words of Tertullian', "At every step and every movement, going out and coming in, dressing and putting on their sandals, at the bath, at the board, when lamps were lighted, when they lay down to rest, when they seated themselves for their daily task, whatever call of ordinary life engaged them, the Holy Sign, by incessant use, was as it were worn into their foreheads." With such associations, it must have been a real joy to them, as often as they discovered the Cross in the Old Testament, where they had not marked it before : it was to them an outward and visible sign of their communion with Saints and Patriarchs of old, and of GoD's everlasting providence over both. It was moreover a perma- 
§ ii. 16,17. nent warning, intelligible to all, against the impiety, not unusual in those days, of ascribing the two Testaments to different deities. People little know what they do, when they deal contemptuously with any thing, be it in Scripture or in common life, under the notion that it is too slight, too insignificant, for the ordering of the Most High.

(16.) All which considered, there appears no fanaticism, but a great deal of sober piety and charity, in the expressions of St. Barnabas on dismissing this topic. "HE knows" the reality of this mystery "from whom we," Christians or Christian teachers, "derive the ingrafted gift of that teaching, which is properly His. Never have I delivered to any one a more genuine exposition, but I an well assured that you are meet to receive it."

If the writer had been merely indulging his own fancy, this profession of reserve would be mere affectation. But surely, to esteem it such is too hard a supposition, considering the perfect simplicity and moral purity of the precepts at the close of the Epistle. His very tone and manner, then, creates an additional presumption, that the exposition which he had been giving was not private but ecclesiastical, and the sort of scruple, with which he imparts it, an instance of that discipline of reserve, which the Church recommended in the conveyance of all her mysteries.

(17.) Neither need any one be staggered at the idea, which his manner of speaking at first sight appears to imply, that Abraham himself was not ignorant of this mystery; a notion upon which Dr. Whitby has built what he conceives to be a triumphant refutation of the allegory. "'The Hebrew letter Tau'", he observes, "neither bears the form of the Cross", nor is the symbol of the number three hundred; and as to the Greek letters, they were not invented till long after Abraham's time." Well; but does St. Barnabas affirm that Abraham himself knew the meaning of this Greek cypher? If he did, he might suppose it made known by prophetic inspiration; according to the received exposition of the text in St. John, "Your father Abraham

${ }^{1}$ De S. S. Interp. p. $9 . \quad 2$ See S. Jerome on Ezek. ix. 4. t. v. pars i. p. 95, 6. 
rejoiced to see my day." But what are St. Barnabas' own

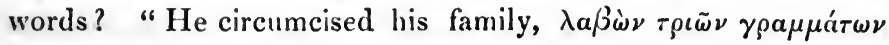

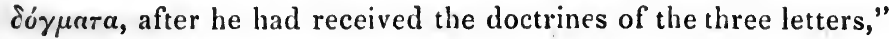
$i$. e. certain mysterious truths, of which the three letters were to be a symbol. It is not said, he received them by the three letters.

Again, after stating the number of the household, he asks,

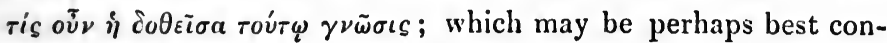
strued, "What is the evangelical meaning of the signs given to him?" taking $\gamma \nu \tilde{\omega} \sigma \iota s$ objectively, for the truth sealed up, not subjectively, for the impression on Abraham's mind. It is not therefore necessary to understand St. Barmabas as asserting, that the holy Patriarch himself had this secret revealed to him. For any thing he affirms, it might be a $\gamma \nu \tilde{\omega} \sigma \iota s$, the outward cypher of which only was given to Abraham, the key reserved for the times of our Lord and His Gospel.

And after all, a mistake in that particular could not fairly invalidate the whole interpretation. There is a school of theologians, which maintains that Aivel must have known the full doctrine of the Atonement. Those who hesitate in allowing this, do not therefore necessarily doubt the typical and mystical import of Abel's history. So in this case, we might believe St. Barnabas, stating what was known in his time to be the signification of the three letters, while we demurred to his supposition, that it was known also to Abraham.

(18.) There is yet one more instance, in this ancient epistle, of allegorical interpretation with reference to the Cross of our LORD : an instance which like the former may stand at the head of a class, and being well considered, may throw much light on another wide province of the so called mysticism of the Church. "Let us see," says the writer", "whether the Lon b has seen good to give men prophetical indications of the Water and of the Cross." Then, after other texts, he alleges the first Psalm, "He shall be like a tree planted by the rivers of waters, that bringeth forth his fruit in his season; his leaf also shall not wither; and whatsoever he doeth shall prosper. The ungodly 
§ii. 19. are not so: but are like the chaff which the wind driveth away; therefore the ungodly shall not stand in the judgment, nor sinners in the congregation of the righteous. For the Lord knoweth the way of the righteous : but the way of the ungodly shall perish." Then, "Observe," says he, "how distinctly the prophet has pointed out the tree and the water in combination. For what he says, comes to this: 'Blessed are they who, setting their hope in the cross, have descended into the water : for I will render their reward in its time,' i. e. hereafter. But for the present, the Psalmist adds, 'his leaf shall not wither,' $i . e$. every word which shall go out of your mouth in faith and love, shall be to the conversion and hope of many." The allusion to the Cross is here brief and obscure, turning as it does upon the single word rò zí $v o \nu$. But the moral of the passage is surely most noble and beautiful. "The Cross, applied by Holy Baptism, gaining the victory over the powers of the world, is not only the pledge and mean, but also the emblem, of the faithful man's triumph over his spiritual enemies. It is the pattern, as its LoRD is the giver, of all victory. And therefore, blessed is the man who walks strictly according to all the rules of a holy life : for he is like the Cross of Christ ; his success is sure, his lot, to bear fruit eternally without stint or measure."

Every one must admire the thought, but the question now is, how it is derived from the Psalm. The account of which, and of many like texts, seems to be as follows: The old Christian writers, either by tradition, or by a feeling so general that it seemed almost like a natural instinct, believed that the phrase rò $\xi \dot{v} \lambda o v$, wherever introduced in the Old Testament, was intended to lead their thoughts to the cross ; of which in their ordinary speech, тo $\xi u ́ \lambda o v$ was perhaps the most frequent appellative. Accordingly, not only such obvious analogies as Isaac bearing the wood of his sacrifice, the Brasen Serpent, or such a place as that in Isaiah, "The government," i. e. the sign of power, the victorious Cross, " shall be upon his shoulder,"-but every rod also, or staff, or sceptre, mentioned by either of the sacred writers, as it was a token of guidance, support, or dominion, was, in the Fathers' judgment, a designed emblem of the Cross.

(19.) The best way, perhaps, of exemplifying this, will be to tran- 
scribe from Justin Martyr's dialogue with Tryphon, which may be considered as a popular view of the prima facie evidence for Christianity in the Old Testament, the remarkable passage ${ }^{1}$ in which he undertakes to prove, that " since the time of our LonD's crucifixion, there hath been inseparably associated with Him that which is an emblem, on the one hand, of the tree of life, the plantation of which in Paradise had been matter of early revelation; on the other hand, it is also an emblem of the course appointed by the Almighty for the righteous." This passage, then, professedly gives the view, which the Christians of Justin's time took of large portions of the ancient Scriptures : and it is noticeable also on another account, that it has attracted the especial scorn of rationalist writers : the language, for example, of Middleton concerning it, is marked (I had almost said) by brutal irreverence $^{2}$. However, thus Justin proceeds :

"Moses with a rod was sent to redeem the people; and bearing this in his hand, in the place of sovereignty over them, he divided the Red Sea. It was by this that the rock gave forth water, gushing out in his sight. It was a tree which he cast into the waters of Marah, which being bitter were so made sweet. It was by means of rods cast into the water, that Jacob caused the sheep of his mother's brother so to conceive, that the young might fall to his share. With his rod, or staff, he, the same Jacob, passed over the water [of Jordan] as he himself boasts. He declared that a ladder had been seen by him, and that it was God Himself who was stationed on the top thereof, the Scripture hath expressly affirmed." This example is not irrelevant, since a ladder is part (so to speak) of the furniture of the Cross. Then having digressed on some other emblems occurring in the vision at Bethel, Justin goes on: "It was the rod of Aaron, which by its budding declared him High Priest. That as a rod from the root of Jesse Christ should be born, Isaiah foretold; and David saith that the righteous man is as the tree planted by the river of waters, which shall bring forth his fruit in its season, and his leaf shall not wither:" where we have Justin's sanction for the interpretation

${ }^{1}$ Opp. p. 312-314. 2 Free Inquiry, \&c. p. 29. 
§ii. 20. which St. Barnabas had given before him. "Again, he saith, 'The righteous shall flourish like a palm.' From a tree God appeared to Abraham, as it is written, at the oak of Mamre. Seventy willows and twelve fountains the people found, having passed over Jordan. By a rod and a staff, David affirms that he received comfort from his GoD. It was wood which Elisha cast into the river Jordan, and so brought up the iron of the axe, wherewith the sons of the prophets had gone forth, to cut timber for building that mansion, wherein it was their purpose to recite and study the law and the commandments of God. Even as when we were plunged deep in the most grievous sins, which had been our practice, by His Crucifixion on the tree, and by the water of His Purification, our Christ redeemed us, and caused us to become an house of prayer and adoration [to Himself]. Also, it was a rod which manifested Judah to be the father of those [twins] who were so born of Thamar, as to exhibit a great mystery."

(20.) From this enumeration, which contains in brief the substance of a great body of commentaries, the chain of ideas is at once apparent, which led to the mystical exposition of the first Psalm. As in the former instances, the uplifted arm of Moses, and the cypher inclosed in the number of Abraham's household, it was the form of the Cross which conveyed the divine intimation : so here the material of the Cross is found indued with the like emblematical virtues.

Again, as St. Barnabas had produced this Psalm as shadowing out a mystic combination of the Cross and the Water, and therefore representing the condition of Christian people; so in almost all the anecdotes, parables, and allusions, collected by Justin in this passage, the like combination is observable. Thus, to take the history of Moses, the virtue of his rod was shown at the Red Sea, and in bringing water out of the rock; the water of Marah was sweetened by the tree which he cast in : the trees and fountains of Elim seen together, were the earnest of hope to the Israelites at their entrance on the wilderness. Elisha's causing iron to swim was a token, as we have seen, of our deliverance "by the crucifixion on the tree, and the water of purification." 
It will be at once seen what a strong light is thrown, by such a $\$$ ii. 21 . series of examples, on the doctrine of the Sacraments, as held by that generation. The Cross and the Water, it is taken for granted, go together to save a man.

(21.) But in order to appreciate rightly the Fathers' reasoning in such places, we ought of course to recollect, that its force lies in the accumulation of instances. It is not necessary that each anecdote, taken by itself, should be a complete type of the evangelical truth, at which the sum of the whole points : $e$. g. though a person questioned the distinct allusion to any Christian mystery, in the account, taken singly, of Jacob's using rods to influence the breed of Laban's cattle, still it must come in as one among many examples, to show how constantly the Almighty employed that material, which was to be the instrument of redemption, as a conveyance of temporal blessings to His chosen people.

Nor must we omit the scriptural sanction, which may seem to be vouchsafed to this whole class of symbols, by the mention in the New Testament of the ark of Noah : on which Justin himself comments elsewhere in the following way ${ }^{1}$. "In Isaiah it is said by the Almighty to Jerusalem, I saved thee in the deluge of Noah." (He seems to be quoting, not in words but in sense, that portion of the 54th chapter, "As I have sworn that the waters of Noah shall no more overflow the earth, so have I sworn to be wroth with thee no more.") "Now," proceeds Justin, "this is the declaration of GoD, that the mystery of those who were saved by Christ was exhibited at the deluge. For the righteous Noab, with the rest at the deluge, . . being eight in number, had a token of that eighth day, on which our Lord CHrist showed Himself risen from the dead : the eighth day numerically, but virtually the first, from the beginning. For Christ, as He was the firstborn of every creature, so He became anew the beginning of a fresh race of men; viz. that which was regenerated by Him, through Water and Faith; and also, we may add, by Wood, since wood expresses the mystery of the Cross. Even as Noah also was preserved by wood, floating upon the waters with those who 
\$ii. 22, 23. belonged to him. When therefore the prophet says, 'I saved thee in Noah,' he is speaking to that people, who, like Noah, are faithful to GoD, and have the same tokens from Him that Noah had."

Thus far St. Justin the Martyr, shewing how, in the history of the ark, there was a designed allusion to the Cross; and by parity of reasoning justifying the like exposition, wherever it has seemed good to Almighty God to use the material of the Cross, namely wood, in the machinery, so to call it, of His miraculous providence, over those who, in their several ages, were to prepare the way of His CHRist.

(22.) For this may be observed of all the instances, enumerated above from Jewish or Patriarchal history, (and I remark it on account of those especially, who may be inclined to treat the subject lightly) that, one and all, they are discernible links in the providential chain above mentioned; they all relate to critical moments in the history of the chosen seed. Thus, the supernatural increase of Jacob's flock, by means of the rods, was the first great step towards the increase of the chosen family into a nation : and again, Judah's staff, the producing of which as his token, stayed the sentence of death against Tamar, was thereby instrumental in preserving the life of her infant, in whom it was Gop's purpose to continue the chosen seed.

Perceiving, as we do in these cases, something of GoD's design in interfering, it surely becomes us to treat those traditions with reverence, which teach that in the manner of interfering $\mathrm{He}$ had respect continually to the end of the whole dispensation, $i$. e. to the Cross of His Son. And if we find other instances alleged, whose place in the divine œconomy we are as yet unable to make out, let us not rashly treat them as trifling or fanciful. If we do not see their force at first, if they appear to us quaint and overstrained, it is surely possible that this our ignorance may be our own fault or our own trial; it is no absolute proof that the old interpreters are wrong.

(23.) In quitting for the present this subject, of the types of the Cross in the Old Testament, I would just remark further, that it furnishes a clear and instructive example of the manner in which 
the Fathers passed from one branch of mysticism into another; from allegorizing the word of God, to spiritualizing His works. We have seen how they found, or thought they found, a designed remembrancer and token of the Cross, wherever either its material or its form occurred in the Old Testament : and full as their minds evidently were of the Scriptures, it was but one step farther, to carry the same association with them, which way soever they turned, in common life, or among natural objects. For example, so ordinary a sight as that of a flourishing tree by a river side could hardly fail to excite in a devout mind, thoroughly familiar with the Psalms, the remembrance of the description above quoted, with which that divine book opens; which description again, as we have seen, was in a primitive Christian's mind inseparable from thoughts of the Cross and of the Font.

Here then, among GoD's visible ordinary works, we obtain a standing type or symbol, and,-bearing as it does the mark of selection by the Holy Grost, may we not venture to call it a pledge,-of His great invisible work in Holy Baptism; the grace of which, we are thus taught, diffusing a kind of insensible virtue through the whole of our renewed nature, causes a man to grow in the likeness of CHRIsT, to partake more and more of His Cross, and so to have surer and surer hope, that "look, whatsoever he doeth, it shall prosper" for ever.

By this and other like instances, a window being once opened for the lamps lighted within the Church to stream here and there upon the external world, it was rendered easy for a devout and contemplative mind to invent and pursue like trains of thought, in other instances, less expressly warranted in Scripture.

(24.) To take an instance from the subject which has now employed us : the early Christian writers repeatedly point out, in nature and in common life, what they regard as designed providential intimations of the doctrine of redemption, or some part of it, by association either with the form or with the material of the Cross. This they do, not only in flights of devotional poetry, or in what might be considered the indulgence of a meditative imagination, but in serious argument even with unbelievers. So in Justin's well-known appeal, where he is asserting the dignity of the 
§ ii. 24. Cross ". "Providentially," he says, " it was so ordered, that in no instance, in the legend of any of those who were called sons of Jupiter, did the Evil Spirits enact the death of the Cross. For it was not understood by them, all the prophecies of it being symbolically expressed. Now the Cross, as one of the Prophets (Habakkuk) foretold, is the most potent symbol of His power and sovereignty; as appears even from things daily before our eyes.

"For consider all the affairs of the world : is there any, in the ordering and due combination whereof, this form does not occur? There is no crossing the sea, except this triumphant sign, which, in that instance, is formed by what they call the yard-arm, remain entire in the vessel : neither without it is there any plowing the land: neither those who dig in the ground, nor those who work in handicrafts, can perform their task, but by tools having this form: nay, and the human figure differs from animals without reason in nothing so much as in being erect, and in admitting extension of the hands each way:" (which association, we may remark by the way, Holy Scripture itself might suggest, by the posture of Moses ensuring the defeat of Amalek). But to proceed with Justin: "The human countenance," he adds, "bears this also as a mark of distinction from brutes, that from the forehead the line of the nose is drawn out with a sort of prominence ; so that where the breath of life is drawn, there the lines exhibit no other figure than that of the Cross: which the Prophet also hath thus expressed ${ }^{2}$ : 'The very breathing of our nostrils, is CHRIsT the Lord.' Moreover your ensigns also," (he is speaking to the Cæsars) "express majesty by this form, wherewith you every where solemnize your processions; in them exhibiting the signs of your sovereignty and power. It is so, though it be unconsciously done on your part. When your emperors die, their images in this form are dedicated by you; and in writing thereon, you style them gods."

"Thus," he concludes, "having urged you to the best of our power, both by reasoning, and by this appeal to a visible form, which is continually meeting your eyes, we consider 
ourselves to have done our part, and not to be responsible, should you remain unbelievers."

(25.) One would have supposed, that at least the piety and good meaning of such trains of thought might remain unquestioned, by all believers in the Cross of Christ, whatever judgment might be formed on their logical accuracy. Yet, so it is, that on passages of this kind a charge has been grounded against the Fathers, of directing the " faith of their readers to the efficacy of the figure of the Cross, rather than to the Atonement made thereon." A charge which might perhaps be tenable, could it be proved that the general views and conduct of the same Fathers were such as to contradict their truly believing the Atonement. Just as, if there were any persons, either in ancient or in modern times, who observed no rules of self-denial, we might conclude at once that any trust they had, or taught others to have, in "CHrisr crucified," was in fact a trust in a certain form of words, not in the virtue itself of that blessed sacrifice. What was the Cross, as employed by the Fathers, but a "Verbum visibile," recalling to the minds of the baptized the very truth which they are thus accused of slighting; and to the heathen themselves conveying so much as this, that the Gospel was essentially a doctrine of the Cross, a doctrine of suffering in adherence to a crucified Redeemer? As an expressive symbol, therefore, or word, the Sign of the Cross was liable to the same abuse with words in general : the self-deceit of man might enable him sometimes to acquiesce in the sign without the thing signified; and such a caution might be occasionally needed, as Wesley is reported to have received from William Law : "Remember that a man may deceive himself as easily by the phrase, 'justitication by faith,' as by any other combination of syllables."

But supposing no such practical proof against them, may we not say, that the Fathers' veneration for the Cross is prima facie as much a proof of their receiving the doctrine of Cinsist crucified, as any form of words in which they could possibly have expressed themselves? And there was this plain and material reason, for their preferring the visible symbol to any mode of speech, in treatises for general reading; that they did not thereby convey more knosledge, than the rule of the Church allowed, to those who were without, while to every baptized believer they conveyed 
$\S$ ii. 26. intimations, deep and solemn in proportion to the depth of his faith.

(26.) But not only with the figure of the Cross, but with its material also, the piety of those times associated divine relations and recollections; tranferring, by an easy process, the mystical allusion, which the New Testament expressly sanctioned in the case of the ark, not only, as before mentioned, to other scriptural facts, such as that of Elisha causing the iron to swim, but also to occasions of common life; such, for example, as that mentioned by St. Cyprian, where he comforts certain imprisoned confessors, with thoughts, which to the world may seem merely enthusiastic and fanciful; but let not us rashly apply such words to the reflections of holy men, suffering for the truth's sake, on the circumstances of their trial; circumstances which others might term casual, but which they feel to be providential. Thus, I say, St. Cyprian writes, to Nemesianus and other confessors, condemned to the mines ${ }^{1}$.

"The circumstance of your having been first beaten with staves, and by severe pain of that kind begun to solemnize the first glorious stage of your confession, has nothing in it that we need abhor, or earnestly deprecate. For those limbs of yours, christened as they were, and having all their hope in the Wood of the Cross, shrank not for terror from the wood of the persecutors' staves. The sacrament and token of his salvation was recognised by the servant of Christ. Redeemed before by wood to eternal life, by wood in another form he now finds himself borne onwards to his crown."

This passage may serve as a specimen of the manner, in which those first Christian moralists improved things, seemingly trivial, to spiritual associations. Those who merely make light of such allusions, know little of the real comfort they are calculated to give, to minds over depressed, perhaps, by sickness or privation. And may we not also say, they know but little, I fear we all know far less than we ought, of that serious and thankful frame of mind, which fears to accept such consolations, without owning a special Providence in them, and regarding 
them as real tokens of the greater blessing, with which they are associated ?

So far we have traced the chief mystical expositions, relating to the Passion of our Lord, in the epistle of St. Barnabas ; and we seem to perceive that they are but so many specimens (so to call them) of as many groupes of allusions, constantly occurring in the remains of the early Church.

(27.) There is yet one other aspect, in which the Wood or Tree of the Cross was contemplated by the Church of the first ages, viz. as bearing a designed reference to the fatal wood, or tree of knowledge in Paradise. This is put plainly and forcibly by St. Irenæus, (v. 17,) in a passage which it may be well to quote at length, as containing perhaps the best illustration that can be given of this whole subject. He is demonstrating the harmony of the Old and New Testaments, as different parts of the one great scheme of salvation. And having first pointed to the light thrown by the Incarnation of the Word on the statement, that man was created after GoD's image, he proceeds to argue on the Passion in the following way:

"Not only thus did the Lord manifest both the Father and Himself, but also by His very Passion. For doing away with that disobedience of mankind, which from the beginning had taken place through the wood, or tree of knowledge, He became obedient unto death, even the death of the Cross." The rebellion, I say, which the one tree had occasioned, He heals by that submission, which was wrought in the other. Whereas, had $\mathrm{He}$ been announcing another Father, $\mathrm{He}$ could not, by this sameness of subject, have indicated His coming to do away with the disobedience which had been committed against our $\mathrm{C}_{\mathrm{REATO}}$. But inasmuch as the very same things, which occasioned our refusal to hear and obey God's word, were the instruments whereby $\mathrm{He}$ introduced obedience and entire conformity to $\mathrm{His}$ word, He openly shows Himself hereby to be that GoD, whom in the first Adam we offended, not performing His commandment; but in the second Adam we are reconciled to the same, having become obedient unto death. For to no other were we

vor. vi. -89 . 
§ ii. 28. debtors, but to Him, whose commandment also we transgressed from the beginning." And presently after, " $\mathrm{He}$ hath blotted out the handwriting of our debt, and fixed it to His cross, that as by the tree we were made debtors to GoD, so by the tree we might receive remission of our debt. This hath been shown in symbol through many, but more especially through the prophet Elisha." Then after relating the miracle as above quoted by Justin Martyr, Irenæus proceeds, "Thus by action the prophet showed, that the solid" (which word seems to mean "enduring, irresistible") "WORD of GOD, which we through negligence had lost and could not find, we shall recover through the dispensation of the Tree or Wood. For that the axe is in some way a figure of the WORD of GoD, St. John the Baptist shows, speaking of Him : 'Now also is the axe laid to the root of the trees.' And Jeremiah in like manner says, "The Word of the Lord is an axe cleaving a rock ${ }^{1}$.' Him, then, before hidden from us, the dispensation of the Tree or Wood hath now manifested. For since by the tree we lost $\mathrm{Him}$, by the tree again $\mathrm{He}$ hath become evident unto all; shewing in Himself the length, and height, and depth, and breadth; and as one of our elders said, by the divine extension of His Hands, gathering the two peoples unto one God. For the Hands are two, because there are also two peoples, scattered to the ends of the earth; but the Head in the midst is one, because there is one Gop, who is over all, and through all, and in us all."

(28.) In the other Apostolic Fathers, I do not know that more than one instance occurs of the mystical mode of interpretation ; but nothing is to be concluded from this omission, inasmuch as we seldom or never find either Hermas, Ignatius, or Polycarp, quoting the Old Testament at all. St. Hermas indeed hardly quotes the New, perhaps because the parabolical air of his treatise was better preserved by avoiding such definite allusions; or because (which seems not improbable) the sacred Books, many of them, had not yet come into his hands. And of the other two venerable Saints, it may be observed in general, that

1 C. xxiii. 29. 
in no part of their writings had they occasion to enter into §ii. 28. debate, either with Jews or with impugners of the Old Testament; which two controversies generally called forth the mystical principle of interpretation in the subsequent age.

But in the epistle of St. Clement there is a well-known passage, which proves that by him, at least, that mode of exposition was neither unknown nor disapproved. Having related the history of the harlot Rahab, as an argument of God's blessing on faith as shown by hospitality, he proceeds ${ }^{1}$ : "They went on to give her a sign, viz. that she should hang a scarlet thread from her house ; foretokening this, that by the blood of the Lord shall be redemption to all who believe and hope in GoD. Behold, my beloved : not only faith, but prophecy was in this woman." As if he had said, "It was not a simple case of an individual sinner of the Gentiles preserved by faith; but GoD so highly favoured her, as to make her person and history a prophecy by action, of the salvation which should be by the Cross."

Now this single instance, well considered, appears to bring the question of the mystical interpretation, as it were, to a point. Here is a writer (one is more than half afraid to speak in such a tone of one who came so very near the Apostles, but, if we must so speak of him, here is a writer) of the very highest human claims; the chosen, orlained friend of St. Paul and St. Peter; a person of the greatest practical good sense, as every part of his epistle shows; full of deep piety, and reverence for the holy Scriptures of GoD; of a flowing style, and abundant in resources both of imagery and of language, so that he was not under the temptation, which an ordinary writer might feel, of inserting such topics as happened to present themselves, whether satisfied with them himself or no: moreover, he was evidently not carried away by a passion for allegorical interpretation as such, as is proved by the fact that this of Rahab is the solitary instance in which he employs it. Now, can we believe that such a person, so circumstanced, writing in the most solemn way on the most sacred of all subjects, and on an occasion which must have recalled most forcibly the memory of St. Paul, his father in the

11 Ep. ad Cor. c. xii.

D 2 
\$ii. 28. faith, not long since dead:- can we believe that he could have delivered such an exposition, and applied to it the sacred name of Prophecy, publicly and authoritatively, speaking as he did for the Church, and not for himself only:-had he not been sure that he was uttering the mind of the HoLY Grost? I much fear that we do but betray our own comparative irreverence and indifference towards GoD's holy and awful truth, when we are forward to suspect $\mathrm{His}$ favoured and accredited servants of such light extemporal dealing with $\mathrm{His}$ word. Surely the less violent supposition is, that St. Clement knew what he was saying, when he thus taught or rather reminded the Church (for he speaks not as conveying a new truth, but rather as exemplifying one already acknowledged) that the colour of scarlet, providentially employed as a token and means of deliverance, was an earnest of the Atoning Blood, to be sprinkled, like that of the Paschal Lamb, over the door-ways of those who should be heirs of salvation. Whereby he has also confirmed the analogous interpretation of those places, where scarlet is enjoined as the colour to be used in sprinkling and other legal purgations; and has sanctioned the notion of the many subsequent writers, by whom that colour, whether found in Scripture or in nature, is constantly regarded as oikeiov (to speak rhetorically) to the Passion of our LORD : as much intended among colours to symbolize His Blood, as the shape of the Cross among forms, or its material, wood, among substances.

Whatever warrant he had for saying what he has said of the call of Rahab, the same, or like it, Tertullian (e. g.) may have had, for referring the text in Isaiah',- "Though your sins be as scarlet, they shall be white as snow : though they be red like crimson, they shall be as wool ;"- to the different degrees of guilt incurred by the Jews, first as murderers of the prophets, afterwards as crucifiers of our Lond. "The word crimson," says he, "denotes the blood of the Prophets ; scarlet, that of the LorD, as excelling in lustre." Irenæus again, mixing up his commentary with thoughts yet more awful" ; "Rahab the harlot, condemning herself as a heathen guilty of all kinds of

1 i. 18.

2 iv. 37. 
sin, received and hid within her home" (he does not say two, but $\S$ ii. 29. three spies or watchers) "the Three Explorers who were exploring the whole earth, the Fatrer namely, and the Son, with the Holy Grost." Which words are not to be so understood, as if Irenæus were affirming the Three Divine Persons to have then revealed themselves visibly and personally; since it is a material part of the main argimment of his work, to show that all visible manifestations of the Eternal Father, in the times of the Old Testament, were made through the only-begotten Sos: but he means, apparently, that Rahab and those like her, receiving those who come in God's Name, do in fact receive Him. He goes on with the history of Rahab; "When the whole city where she dwelt had fallen into ruin at the sound of the seven trumpets, in that extremity Rahab the harlot was preserved with her whole house, by the faith implied in that sign of the scarlet thread: even as the Lorv declared to those who would not receive His Advent, to the Pharisees, and such as make light of the sign of the scarlet robe, which was also a token of the Passover, the redemption and withdrawing of the people from Egypt,-to the despisers thereof, I say, the Lond declared, 'The publicans and harlots take place of you in the kingdom of heaven." And Justin, in like manner; adding a remark, that the messengers were sent by Him who bore the Name of $\mathrm{JEsus}^{1}$; "The symbol of the scarlet line denoted the token of CHRist's Blood, whereby men of all nations, formerly impure and unjust, are saved, receiving remission of sins, and sinning no more."

On this whole history we may remark, as on that of Jacob before, that it bears on a critical point in the progress of the great dispensation, and on the continuation of the sacred line in which Christ was to be born. Also, that each of the successive writers (and the chain might be continued much further) notices, not ambitiously but naturally, some circumstance unobserved by his predecessors; so that the whole, taken together, forms an allegory much more complete and striking, than we find in either of the statements taken singly. Dare any man deny, that these are great marks of Truth, even according to our modern measures, incompetent as they obviously are to these investigations?

1 Dial. cum Tryph. p. 338. D.; Ed. Paris 1636. 
$\S$ iii. 1.

(29.) We have thus endeavoured to trace one set of mystical allusions, those, namely, which are drawn from the circumstances of our Lond's Passion, throngh the interpretations of the Old Testament, left us by the Apostolic Fathers; and also to illustrate them from the Fathers of the next generation, so far as to give some idea of the kind of consent, in their mode of expounding, which is found among them all : an agreement not in minute particulars, as if they borrowed from one another, nor yet as if they were bound down in common by any strict ritual, or hieroglyphical alphabet; but rather in a way which cannot, perhaps, be better expressed, than in the words of St. Augustin', where he lays down the principle which guided him in the investigation of historical types. "These secrets of Divine Scripture we trace out as we may, one more or less aptly than another, but as becomes faitlful men, holding thus much for certain; that not without some kind of foreshadowing of future events, were these things done and recorded; and that to Christ only, and His Church, the City of God, are they to be referred in every instance," so far as they are figurative.

On the true cause of this very general agreement, some considerations will be offered hereafter, which may at least have the effect of helping us all to think with seriousness of heart, on a subject, which scholars in general have, perhaps, been apt to treat over-lightly, not to say profanely ; so that, in speaking of it, a person insensibly falls into the apologetic tone. But the more we really come to know and think of it, the more deeply, perhaps, shall we feel, that even that tone is inexcusable presumption, compared with what would become us, in making mention of those who come nearest the Apostles, and had in greatest perfection the mind of $\mathrm{CHRIST}_{\text {. }}$

\$ iii.-The Literal Sense left entire by the Mysticism of the Church.

No impression, I believe, is more general among ordinary readers of theology, than this; that beyond a strong tendency to allegory, the Fathers had no definite principles at all, by which to

'De Civ. Dei, xvi. 2. 
interpret Scripture, but only employed, in a rhetorical way, whatever allusions best served the purpose of the moment. A remarkable and not a very encouraging fact, if such really were the case, that such a series of distinguished writers, - writers whom their very censurers ' allow to have greatly exceeded the mass of their contemporaries,-zealously applying themselves to this one work, and with a devotion and reverence as sincere, in very many cases, as martyrdom could prove it; - that these should have gone on quite at random, and have been right, when they were right, only by a happy chance. Nor would it seem easy to reconcile such a statement with our LorD's command to search the Scriptures, and with His implied and express promises of spiritual aid ; unless we were prepared to maintain, what all history contradicts, that the Fathers either neglected the Bible, or forfeited the promise of aid in the study of it by gross heresy, or insincerity, proved by ill conduct.

But is the fact so, that they were without principles of interpretation? Is it not rather our want of steady attention and reverential industry in examining the whole subject, which makes it seem so to us? It is readily allowed that there exists a peculiar difficulty, in evolving the patristical rules for expounding Scripture, on which difficulty something will be presently said. But that some such principles, however latent, do exist, we might confidently gather from this one fact; that no one, tolerably versed in their writings, would fail to detect their style of interpretation, wherever he met with it, by something in its air and tone; something not the less real, because it may be to us indescribable in words. Let any one, for example, compare the commentary of Quesnel on the New Testament, or that of Wogan on the Proper Lessons, both which are expressly founded on the ancient glosses, with the explanations of Scripture interspersed in the "Pilgrim's Progress." Both being to a high degree allegorical, he will yet find the one throughout of a different caste and family from the other.

(2.) Now it is no wonder if we find it difficult to seize in distinct thought, and embody in language, the exegetic principles of the

${ }^{1}$ See Warburton, Int. to Julian, Works, iv. 340, 341. Ed. 1788. 
§ iii. 3. old Church writers, since, in all probability, few, if any, of them were ever able to do so for themselves. With an instinctive skill, acquired, in part at least, by long and zealous training of themselves in that one department, they felt when any exposition or conjecture, which occurred to them, was.(to use their own word) Ecclesiastical, and when otherwise. It was a happy sagacity, which could afford to dispense with all manner of critical and argumentative development. They were natives, and could speak the language idiomatically, without stopping to recollect rules of grammar.

And here we seem to have no inconsiderable proof, that the mystical interpretation was no result of a theory subsequently introduced among Christians; it was not this or that writer's importation or invention, but it was from the beginning habitually inwrought into the thoughts and language of the Catholic Church.

Hereby also we have suggested to us a way for attaining to a virtual knowledge of their rules of interpretation, though we perhaps may never be able, any more than they were, to trace out those rules in language. We have only to exercise ourselves much and deeply in their expositions of Holy Writ, and in the same devout observances which we know they kept up, and we too shall gain by degrees their practised eye-whereby to discern their first principles. This would be one way, and on every account the best way, of convincing ourselves that the mysticism of the early interpreters is not the vague, unsettled, dreamy kind of view, which many of us are at first hearing apt to imagine. We may set ourselves to study the examples of it thoroughly in detail : and finding, as we shall in a great proportion of them, a great deal more than we had expected, we shall gradually and surely learn, both to value the method more highly, and to understand it better.

(3.) With this view, some examples have been given ahove: examples purposely selected, many of them, as the likeliest to startle and scandalize a mere modern reader; and something, it is hoped, has been done towards shewing, that in those cases at least the holy Fathers well knew what they were about; that they proceeded, in interpreting Scripture, on 
the surest ground-the warrant of Scripture itself in analogous $\S$ iii. 4, 5. cases.

Another process, leading to the same conclusion, would be to examine, fairly and fully, whether there be not certain limitations which the Fathers carefully observe in their application of the mystical method; certain bounds within which they confine themselves, as did champions of old within the rules of the tourney, in the utmost heat and speed of their career. Some indeed of these rules are laid down in express words by the more exact and argumentative of the Fathers: others we may gather with sufficient assurance from the comparison of their comments. To this subject, then, the limitations of the mystical exposition, as they were generally recognized by Antiquity, we are to address ourselves in the present stage of the inquiry.

(4.) The first and most obvious of these rules of limitation was, not to lose sight of the letter; to reserve in every mystical comment the foundation of historical and literal truth. This, as all men know, is one of the points on which the Fathers have been most confidently assailed; but, as a few plain considerations will show, most unjustly.

For, first, the evidences of the Christian religion were from the beginning chiefly historical : such as the records of the life of CHrist, the ministration of the Apostles, and the facts by which, in the old dispensation, GoD had authorized His messages by $\mathrm{His}$ prophets. The faith had been received in the first instance, as to the main body of it, in the plain literal and historical sense. It was so accepted by the mass of believers, as the Old Testament had ever been by the mass of the Jews ; and surely appeal might be made without hesitation to those who are really versed in Christian Antiquity, whether even the most daring mystics among them do not all along assume the truth of the history ; whether the mere allegory, which they sometimes appear to maintain, be at worst more than an exception to a general law; a resort in difficulties; a solecism, not a rule.

(5.) But secondly, if in any case they seem to press the allegory beyond this, there are considerations which would lead a sound critic to be cautious in urging their statements in that kind 
\$ iii. 5. further than their very words oblige us to go. There are reasons which should induce us to give them all the benefit of any qualification or ambiguity which their expressions admit of,-to construe all that is equivocal in favour of the literal meaning. Were they not in a great measure free from some of the temptations, which have ever been found most effective, in inducing inconsiderate commentators to deal over freely with the letter of the Divine Records? These temptations have commonly arisen, on the one hand, from over refinement in philosophical and moral subjects; on the other hand, from critical skill, and dexterity in sifting statements on matters of fact. Of the first head, philosophical and moral allegory, something will be said by-andby, when we come to the case of those Fathers, who are allowed to have erred in exaggerating the mystical sense. But their general deficiency in critical and historical acuteness is notoriously one of the most popular charges against them, and one of the reasons most frequently given for not deferring to their authority in Scripture interpretation. Those who judge so of them, must at least allow that they were, so far, exempt from that temptation to take liberties with the text of Scripture, which historical and critical difficulties continually offer.

For example, had Origen been as unversed in critical discussion, as were, on this hypothesis, the majority of the Fathers, he would not have been driven, by a supposed chronological difficulty, to throw discredit generally on the letter of the evangelical narrative. So at least he is supposed to have done, in commenting on St. John's account of our SAviour's return to Galilee after the temptation. Not finding how to reconcile that account with those of the other Evangelists, he says ${ }^{1}$, (if his words indeed are rightly so translated,) "The truth concerning these things must needs be lodged out of sight in their secondary and spiritual signification. The discrepancy being so accounted for, we need not relax in any measure our faith regarding the Gospel narratives, as though they were either untrue, or destitute of any peculiar divine inspiration, or failing in their proper office as

1 In Joan. t. x. c. 2. 
memorials." Then having stated the difficulty at length, he $\$$ iii. 6 . concludes, "In this and many cases besides, whoever will carefully examine the Gospels with a view to any disagreement in the narrative, it will either cause him with a sort of mental giddiness to give up the claim of the Gospels to absolute authority, and chuse one of them at random to adhere to, as not venturing to repudiate entirely the faith of our LORD; or, if he still admit all four, he will consider their truth to be lodged somewhere else, than in the outward material words, and letters, and syllables." The amount of Origen's meaning in this passage may perhaps be a subject of discussion by-and-by. At present it is quoted simply for the sake of pointing out the danger incurred by habits of searching criticism, viz. that it leads men, on discovering flaws, to them, incurable, to think more slightly than they ought of the letter of the Bible altogether. It is the genius of modern philology, to cut all such knots, by expressing or insinuating more or less of doubt, as to the plenary inspiration of the Scriptures. Some of the ancients, not perhaps more logically, but with at least as much of religious awe and reverence, had recourse, we see, in the like cases, to the supposition of mere allegory intermixed with the truth. But the far greater number of them, being, as their opponents complain, quite "uncritical," i.e. taking the text as they found it, and not perplexing themselves with difficulties of construction and harmony, were free at least from this one undue bias towards the secondary sense.

(6.) A still stronger and more universal preservative must have been the unfeigned and singular veneration, with which they ever regarded the Holy Book. Whatever else may be laid to the Fathers' charge, even the most scornful and bitter of their censors have been constrained to admit the paramount value which they set on their Bibles, and their thorough acquaintance with them. Even where they mysticised improperly, their ordinary motive was a sincere veneration for the Scriptures; whose dignity, they sometimes with some plausibility argued, could not stand with the literal sense. This was a shortsighted and erroneous feeling, so far as it may have wanted that wise and simple faith, which 
\$ iii. 6. would have caused them at once to receive the very letter, without hoping or pretending to explain all difficulties. Still, there was a feeling here of affectionate and dutiful though mistaken loyalty; like St. Peter's, when he took hold of our Lord and began to rebuke and contradict Him ; saying, "Be it far from Thee, LORD ; this shall not be unto Thee."

Accordingly, when Origen goes off to the mystical sense, it is with him almost always a matter of reverent and earnest prayer.

Thus, having given a careful and sensible commentary on the literal account in Genesis of the building of the ark, he proceeds ${ }^{1}$ : "Now, first beseeching His indulgence, who alone is able to withdraw the veil from the reading of the Old Testament, let us try and make out what spiritual edification also is contained in the raising of this august fabric, the ark."

Again, in his exposition of the parable of the unmerciful servant ${ }^{2}$ : "It is no small matter to express, according to the full mean-

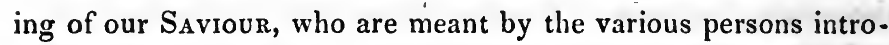
duced in this parable : . . indeed, the very truth of these things, I am bold to affirm, no one shall be able to utter, unless the same JEsus, who privately expounded these things to His own disciples, have entered in to dwell in his mind, and open there all the treasures contained in the parable; dark, hidden, far out of sight. .... I, for my part,-as one who has not yet obtained in sufficiency that mind which can thoroughly penetrate and mingle

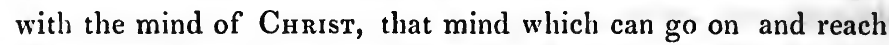
to the end of so great things, that mind which, aided by the Sprrit, can search all, even the depths of God-am able as yet to form but an indefinite notion of the details of this passage."

The expression of awe is, perhaps, still more remarkable, when he draws back from an interpretation which he had actually entered on: as one who caught himself unawares intruding further into the sanctuary than he had intended. It is on the Parable of the Labourers in the Vineyard ${ }^{3}$ : "Seeking out," he

1 Hom. 2. in Gen. § 3. t. ii. 63. A. Ed. Bened. 1733.

2 Comm. in Matt. xiv. $\$ 11$. t. iii. 629. B, C, E.

3 In Matt. xv. \& 31. t. iii. 699. B. 
says, "what might be the 'one day,' which limits the time of this § iii. 7. parable, . . . I I have unwarily taken some steps into certain of the deeps of Almighty GoD; lacking as I do that Spirit which searcheth all things, even the deep things of God."

Surely the tone of mind here apparent could not exist, without a profound veneration for the letter itself and literal meaning, the garb and outward vehicle of truths so revered and precious. Surely it could have been only by comparison, if ever the same writers seem to disparage the letter. And in fact we find that few authors have done more for the elucidation of the historical sense, or given more unsparingly the best practical proof of reverence, unwearied religious diligence in trying to understand. So that with respect to the threefold method of interpretation, which he is known to have generally adopted, a partial judge might almost say of him, and of others like him, as contrasted with modern inquirers, that he had three Bibles to read and we but one; not a jot or tittle failing in his reverence for the body of the sacred Book, compared with ours, while he enjoys, what we generally want, the privilege of contemplating its soul and spirit also.

(7.) Now, if even Origen, the known champion of the allegorical method, felt and practised such regard for the Letter of Scripture, it is surely unnecessary to multiply quotations, in proof of the general opinion of the Church on that subject: her impartial veneration for the whole of the Divine Book, her deep, faithful, and undoubting reception of every part, both in its obvious and in its abstract senses, according to the fulness of the meaning of the SpIrit of God. There is a striking passage in St. Augustin, which collects, as it were, into a point, the confessions on this head of every generation of believers". "The style itself in which Holy Scripture is framed, how open is it to every one's approach, how impossible to be searched out by any but a very few! What things it contains that are obvious and open, those, like a familiar friend, it speaks simply to the heart, both of unlearnerl and learned. As to those, on the other land, which it hides in mysteries, neither does it elevate them by lofty speech, such as might deter from a nearer approach the dull and untaught

'Ep. 137. § 18. t. ii. p. 310. 
\$ iii. 8. mind, as a poor man sometimes fears to approach a rich one; but Scripture invites all by a lowly kind of speech, intending not only to feed all with obvious truth, but also to exercise and prove all by that truth which is remote from view : having in its easy parts whatever its hard parts contain. But lest, being open to view, they should incur contempt, the same truths again are made desirable by concealment ; to meet the desire, they are, as it were, produced anew; and being so renewed, they insinuate themselves with a kind of delight. Thus wholesome correction is provided for corrupt minds, wholesome nourishment for feeble minds, and wholesome enjoyment for great minds. That mind alone is set against this teaching, which either throngh error knows not its healing power, or through sickness loathes it as medicine." Men who were so minded towards the whole Book of GoD,-would it not require overpowering evidence to convince us that they commonly passed by with disdain the letter of Scripture? yet they have been charged with no less than this.

(8.) The improbability of such allegations becomes yet more glaring, when we take into account the universal cast and tenour of the Fathers' doctrinal views. This is a consideration, indirectly indeed, yet really and materially, bearing on the present discussion. Ever since the Church began, she has felt that she had to guard against a tendency to over-refinement and affected spirituality. There has been danger lest the body, so to call it, of important truths, should be exhausted and exhaled away, in their supposed moral and imaginative meaning. This is the error of the people called Friends, and in general of the rationalists of modern days. It was also the error of the Gnostics of old, who denied, as is well known, the reality of the Incarnation and Passion of our Lord, the Resurrection of the Body, the identity of the Creator with the REDEEMER; and whatever other portions of Christian belief appeared to them in any way mixed up with things outward, material, and bodily. Against these, in the beginning as now, the Church of God always protested, maintaining the literal reality of these Truths, as she now maintains the real efficacy of material Sacraments, in opposition to the refinements of plilosophy and vain deceit. Now it was a sort of index to this first 
heretical school, their denying the historical meaning of Holy

Scripture ; as may be seen in many parts of Irenæus. His statements are like the following ${ }^{1}$ : "These vainest of sophists maintain that the Apostles taught not truly but feignedly, according to the capacity of their hearers; that they framed their answers to suit the prejudices of those who at any time were asking them questions; discoursing with the blind blindly, according to their blindness, and with the sick according to their sickness, and with the erring according to their error. Thus, to such as imagiped that the Creator was the only God, they made Him the subject of their preaching; but to those who are able to receive the unutterable Father, they administered by parables and allegories the unspeakable mystery: thus making it cut that our LORD and His Apostles gave instruction, not according to the tenor of the very truth, but in pretence, and according to the capacity of each."

Such are the complaints brought against heretical theorists, by the ecclesiastical writers of those days. Had we no direct evidence on the subject, passages of this sort would warrant us in concluding, that the early Church held to the literal Scripture as her foundation, whatever superstructure of mystical or moral truth she might know and believe herself entitled to build upon it. For there is a natural and very distinct analogy between the doctrines which reject the body, and the expositions which reject the letter. We perceive at once that they belong in their several kinds to the same turn of mind, the same school of opinions. And on the other hand, the straightforward unflinching faith, which is always content to take God's work as $\mathrm{He}$ has made it, will of course be willing also to accept His word as $\mathrm{He}$ has taught it. "When I hear of grass," says St. Basil 2, remarking on the excessive proneness to the mere allegory, by which some had explained away the history in the first chapter of Genesis, " when I hear of grass, I understand it to mean grass, and so of plants, and fishes, and beasts, and cattle ; all of them, as they are spoken, so I receive. For neither am I ashamed of the 
§iii. 9. Gospel." And a little further on : "In the oracles of the Spirit I desire to glorify Him, who has not employed our understanding on vain things, but has dispensed all so as to be written for our edification, and the perfecting of our souls. Of which truth, as I think, some not being aware, have tried, by I know not what allurements and figures of speech, to get the Scriptures credit for a kind of dignity, which in fact is of their own devising. But this is to make one's self wiser than the oracles of the Spirit, and under the show of interpretation, covertly to introduce matter of our own. As it is written then, so let our understanding be."

(9.) There occurs however in the history of early corruptions one case, which would appear at first sight to militate strongly against the reality of the connection here supposed, between fantastic doctrine and interpretation merely allegorical. I mean the case of Marcion of Pontus. He distinguished himself from the main body of the heretics of his time, by denying that Scripture was ever to be understood in any sense but that of the bare letter: at the same time that he agreed with them in rejecting the truth of CHRIst's Body, the resurrection of our bodies, and the other doctrines above alluded to.

But see what line Marcion was obliged to take, in consequence of this extraordinary combination of opinions. He boldly discarded the whole of the Old Testament, as the work of an evil, at least of an inferior being. He retained moreover of the New Testament only one Gospel, St. Luke's, and the Epistles of St. Paul. And to make these at all seem to bear witness in his favour, he was constrained to dislocate and alter the text to a very considerable extent.

It is not within our present scope to show how inconsistent, after all, his admitted Scriptures were with his shadows of doctrine: Tertullian has done so at large, and with more, if possible, than his usual acuteness, in his two last books against Marcion: but the point material to be here noticed is, his sympathizing with the other heretics, and contradicting the Catholic Church, in his irreverence for the letter of Scripture: the only difference being, that he chose rather to take the ground of the Jews of his time, and, in effect, that of our modern rationalists, by denying 
the inspiration of the portions which most perplexed him; instead \$ iii. 10. of wresting them, as most heretics did, by various figures, to his own construction.

Thus it appears that the proceedings of Marcion form no such exception as should invalidate the general rule; and the position stands good, that the Church of the Fathers, maintaining as it did the doctrines which the Docetæ denied, was very unlikely to give undue sanction to their merely allegorical mode of interpreting Scripture; just as the same Church, even yet, arguing with rationalists, refuses to admit that "fire in the prophecy of St. John the Baptist is quenched with the name of the Holy Ghost, or with the name of the SpIRIt, water dried up in the words of $\mathrm{CHRIST}^{1}$," concerning the new birth.

(10.) The drift of all these antecedent probabilities is this : that whatever affirmations are found in ecclesiastical writers strongly in favour of the letter of holy Scripture, are to be credited for their full apparent amount; but for those comparatively rare instances, in which they have permitted themselves to speak lightly of the literal meaning, every kind of allowance ought to be made ; they must be taken, so to speak, at a considerable discount.

Consider, for example, the opening sentences of St. Augustin's treatise, "De Genesi ad literam"." "The whole Scripture of GOD is twofold; according to the intimation of our LORD, when $\mathrm{He}$ said, 'Every scribe instructed into the kingdom of heaven is like unto a man that is an householder, bringing out of his treasure things new and old.' ... . In the relation therefore of things done, one has always to inquire whether each particular is to be received in the figurative sense only, or to be affirmed and maintained as to the actual verity of the facts. For to deny that there are things to be figuratively understood no Christian man will venture, remarking the words of the Apostle, 'All these things befel them in figure ;' as also where he commends to us, as a great mystery relating to CHRIsT

1 Hooker, E. P. v. 50. 3.

2 t. iii. pars 1. p. 90 ; Ed. Bened. 1702.

voL. V1.- 89 . 
\$ iii. 10. and the Church, the expression in Genesis, "And they two shall be one flesh." "

This place has been quoted ${ }^{1}$ as an instance of extravagance in urging the secondary sense, on account, probably, of the possibility intimated in one part of it, that in some cases there may be no true literal or historical sense. But, according to the rule above laid down for interpreting the Fathers on this subject, it is but fair to understand by St. Augustin's doubtful cases, those which may reasonably be considered more or less parabolical; such as Nathan's reproof of David, or our Lond's account of the Prodigal Son. It would be doing him injustice, to charge bim with throwing doubt hereby on any part of the series of sacred history.

On the other hand, when we find the same Father arguing as follows in favour of the reality of Paradise, and of the history of our first parents, we need not hesitate to believe, that he meant his argument to extend, as by parity of reasoning it would extend, to every other portion of the regular inspired narrative. "Those 2 ," says he, " of our faith, who believe these divine books, but like not to have Paradise understood according to the very letter, $i . e$. a most pleasant place, shaded with groves of fruit trees, of immense extent, too, and fertilized by a copious fountain ; seeing as they do, without any labour of man, so many green glades overshadowed with forests by the secret working of the Almighty :I wonder how they believe the corresponding narrative of the formation of the man, in a way like nothing which ever met their eyes. Or if that, too, must.be understood figuratively; who begat Cain, Abel, and Seth? Were they likewise mere figures, not men born of mankind ? I would advise men, therefore, narrowly to consider what is the drift of the notion they are inclined to assume, and to endeavour with us to understand all things, related as facts in the first instance, as they are literally expressed. 'That once done, every one will look kindly on their views of what the same things teach also by figurative expression, either of spiritual

1 Whitby, Pref. in Diss. de Interp. S. S. p. Iviii.

${ }^{2}$ De Genes. ad lit. viii. 4. 
natures themselves and spiritual processes, or of events yet to $\$$ iii. 10 . come.

"I grant that if we could not receive in a bodily sense the things here named as bodily, without doing violence to the faith of the truth, nothing would remain but that we must understand them to be figurative expressions, rather than cast impious reflections on Holy Scripture. But if the bodily acceptation of these things be so far from embarrassing, that it rather more firmly establishes, the general statements of Gop's word, I should not expect to find any one so full of heathenish obstinacy, as to abide by any old opinion, which he may have formed in favour of the mere allegorical exposition, atter seeing the whole explained literally in accordance with the Rule of Faith."

$\mathrm{He}$ then proceeds to state, as the very occasion of his writing that treatise, a wish to improve on a former exposition of Genesis, which he had undertaken against the Manichæans; and in which, not being able at that time to make out the literal meaning, he had assigned to many things an interpretation merely allegorical'. "Still," says he, " even then, keeping in mind that which was all along chiefly in my wish though beyond my power, viz. that every thing in the first instance should be understood not in figure but literally, and not despairing altogether that such an understanding might be acquired, I expressed that feeling in the opening of the second book. My words are, "Whosoever desires to understand every thing according to the sound of the letter, provided he can avoid blasphemies, and all that he affirms be agreeable to the Catholic Faith, his labours must not be taken grudgingly : rather we must account of him as understanding the Scriptures in the proper sense of the word, understanding." "That such from the beginning was St. Augustin's feeling, - that he always preferred the literal sense as the foundation, and only had recourse to the purely figurative, when, as he conceived, the analogy of the faith required it,-he gave the most satisfactory proof, by going over the same ground, writing a more literal commentary, when in process of time maturer reflection had brought to his knowledge more of the literal meaning.

${ }^{1}$ De Gen. ad lit. viii. 5. 
$\S$ iii. 11, 12. (11.) I say, when the analogy of the faith required it ; for this is a very remarkable circumstance in the patristical mode of deviating from the letter of Scripture, especially as compared with those adopted by more modern interpreters : viz. that whereas these latter are commonly moved to set it aside by some apparent inconsistency with the truths of philosophy or history, some scruple of buman reason; the only sufficient plea for such deviation, in the judgment of such critics as St. Augustin, was the impossibility of reconciling the letter with the Rule of Faith. Thus, in the passage quoted above, the excepted cases are described as follows: "Si nullo modo possent salva fide veritatis corporaliter accipi :" "Si nullus exitus datur, ut pie et digne Deo quæ scripta sunt intelligantur, nisi figurate proposita credamus."

And let it not be imagined that by the phrase, "pie et digne Deo," a door is opened for the unlimited intrusion of each person's private judgment. The phrase is sufficiently explained by one which had occurred a few lines above: "prædicare omnia congruentia fidei catholicæ." That was to be judged pious and worthy of GoD, which agreed, not with this or that man's preconceived notions of the divine proceedings and attributes, but with the body of scriptural truth set forth by the Church from the beginning.

If, then, we may suppose St. Augustin here to speak the general sense of ecclesiastical writers on this subject, we shall see that the utmost extent, to which the Church encouraged the use of the exposition by mere allegory, was to bear with it as a possible or at most as a probable hypothesis, in cases where the letter seemed irreconcileable with the analogy of the Faith; always allowing for the chance of some more favoured commentator solving the difficulty without this extreme resort.

(12.) But the true ecclesiastical rule of interpretation will be put in a stronger light, if we consider the case of Origen and his school, and the degree in which they incurred the suspicion, if not the censure, of the Cluurch. And we may notice, by the way, a remarkable instance of the hard measure which has been dealt out to the Fathers, by those who were resolved, at all events, for whatever reason, to derogate from their authority. It is the usual manner of proceeding, with such writers as Daillé, Whitby, 
Middleton, and the rest, to quote largely from the censures of §iii. 13. St. Jerome and others, pronounced on the Origenists for their extravagance in the allegorical way, and then to turn suddenly round, and use these same censures, as if they were applicable to the whole body of the Fathers; especially to St. Jerome himself and the rest who were eager in promulgating them.

But surely the censure might speak the opinion of the Church, though, from human infirmity and inconsistency, the persons pronouncing it might themselves incur it elsewhere.

Again, it should be well considered whether St. Jerome, St. Basil, and others, commonly quoted on this matter, are deprecating the allegorical system itself, or only the particular abuse of it now under examination, viz. the occasional suppression of the letter for the allegory's sake. It may be some help towards estimating rightly the judgment of the Fathers on the whole subject, if a few words be here added, first on the real amount of the concessions of the Alexandrian school in disparagement of the letter; next on the real amount of Church censure, properly so called, which that school incurred, on that ground, in the person of Origen, the most renowned, and therefore perhaps the most obnoxious, of all its champions.

(13.) And first, as to the extent of liberty taken by Origen with the literal sense of the Bible: it is but just to begin with stating, that his faith in the plenary inspiration of Holy Writ, those parts of it even which he is most accused of denying, is as unquestionable as it can be rendered, both by the tone of cordial reverence in every part, and also by repeated glowing professions like the following ${ }^{1}$ :

"By this brief demonstration of the divinity of $\mathrm{J}_{\text {ESUS, and }}$ application of the prophetical words concerning Him, we do in effect demonstrate at the same time the Divine inspiration of the Scriptures which prophesy of $\mathrm{Him}$, and also of the writings which relate $\mathrm{His}$ sojourn here and $\mathrm{His}$ teaching; writings which were uttered with all authority and power, and have thereby become victorious over the elect portion of the Gentiles. It should be added that the divinity of the prophetic words, and the spirituality of Moses' law, shone forth only in consequence of the

\footnotetext{
${ }^{1}$ De Princip. iv. 6. t. i. 161.
} 
\$ iii. 14. [earthly] sojourn of $\mathrm{J}_{\mathrm{ESUS}}$. For evident proofs of the inspiration of the ancient Scriptures, before CHRist's sojourn here, it was not possible to exhibit; but the Law and the Prophets, before liable to suspicion, whether they were indeed things Divine, had a clear light cast on them by the residence of Jesus on earth, as being composed and written by a grace from above. And he who with care and attention studies the prophetic words, feeling as he will on the bare reading a kind of enthusiasm stealing over him, will be convinced by his feelings that they are no writings of men, which we believe to be the words of Goo. The light, too, which existed before in the Law of Moses, wrapped up in a veil, shone forth at the time of our Lond's abode here; the veil being taken away, and the good things, which were shadowed by the letter, coming gradually into full knowledge."

(14.) Next, I observe, that in general, i. e. with comparatively few exceptions, and those always particularly accounted for, Origen did not only receive the letter, but acknowledge the historical meaning, of the Holy Book. This will be sufficiently evident by a few citations, falling into two separate groupes. The first will consist of passages in which he inculcates his much canvassed maxim of a Triple Sense of Scripture : the other, of express or incidental cautions, in the course of his commentary, over and over enforced upon his hearers, not to lose sight of the letter in the brightness of the Spirit.

The Triple Sense of Scripture is most expressly set forth in a well-known passage of the Fourth Book $\pi \varepsilon \rho \grave{i} a{ }^{\prime} \chi^{\tilde{\omega}} \nu^{1}$. "We ought to transcribe into our own souls the meaning of the Holy Writings in three several ways : in the first place, that the simpler may be edified by what may be called the flesh or body of the Scripture, by which name we denote the obvious, literal acceptation : in the next place, that he who has attained to a certain height, may receive edification from that which is as it were the soul of the same Scripture : thirdly, that he who is perfect, and like those of whom the Apostle speaks as fit to have wisdom spoken among them-wisdom not of this world-that they too may be edified out of that spiritual law, which has the shadow of good things to come. For as man is compounded of body, and soul, and Spirit, 
so is the Scripture, dispensed by God by way of gift for the §iii. 14 . salvation of men."

Again, in a noble passage of the fifth Homily on Leviticus ${ }^{1}$,which may be cited the more at length, on account of the light which it seems to throw on the analogy above alleged, as existing between the doctrines of the Fathers and heretics respectively, and their methods of interpreting Scripture :- "The details of the law concerning sacrifices are," he observes, "to be received in a different sense from that which the literal text points out. Else, when they are publicly read in the Church, they tend rather to the hindrance and subversion of the Christian faith, than to the admonition and edification of men. But if we search and find in what sense these things are said, and mark them, as they ought who think of God, who is the declared author of these laws; then the hearer will become a Jew indeed, but 'a Jew inwardly,' according to the distinction of St. Paul in the epistle to the Romans; which distinction of the inward and outward Jew, certain impious heretics not understanding, have withdrawn themselves not from the Scriptures oniy, but from God also, the Giver of this law and of the divine Scriptures to mankind, and have feigned to themselves another God, besides the Maker of Heaven and Earth: whereas, as you know, the verity of the faith holds one and the same God of the Law and of the Gospel, the Creator alike of visible and invisible things: the rather, because the things visible retain with invisible no small affinity; so that the Apostle affirms, 'the invisible things of God, from the creation of the world,' to be seen, ' being understood by the things which are made.' As therefore a mutual affinity exists between things visible and invisible, earth and heaven, soul and flesh, body and spirit, and of combinations of these is made up this present world : so also Holy Scripture, we may believe, is made up of visible and invisible parts : first, as it were, of a kind of body i. e. of the letter which we see with our eyes: next of a soul, $i . e$. of the sense which is discovered within that letter: thirdly, of a spirit, so far as it contains also in itself certain heavenly things; as says the Apostle, 'they serve to the example and shadow of things celestial.' 
\$iii. 15. "Such then being the case, let us, first calling on God, who made of Scripture both the body, and soul, and spirit-the body for those who were before us, the soul for ourselves, the spirit for those who in time to come shall obtain the inheritance of eternal life, whereby to win their way to the heavenly kingdoms; -let us now seek that soul of the law which I have mentioned, so far as belongs to our present subject."

(15.) One may remark, by the way, that the opening of this statement enables us in some measure to solve one principal difficulty connected with the allegorical method; viz. how it came to pass that in public and popular discourses, discourses to the unbaptized, Origen and others so continually and unreservedly publish these mystical expositions; expositions which themselves repeatedly compare to strong meat, hardly fit therefore for the babes and beginners in Christ. This is to be accounted for, probably, much in the same manner as the publication of the Three Creeds, and putting the mysteries of our faith in every one's mouth; it was in itself not desirable, nay rather contrary to Church principles: but the Jews and perverse heretics made it necessary, each endeavouring, for their own purposes, to maintain that the Old Testament was contrary to the New : a position which could not in strict reasoning be met satisfactorily, unless by divulging the secret of the allegorical meaning. Origen himself speaks feelingly of this difficulty, in the course of his remarks on the parable of the Unmerciful Servant". "But some one will say, are we not acting irreligiously in wishing these things to convey a meaning, because of the heavenly Book's secret and mystical nature in some parts? Are we not wrong in trying to expound these things ? however accurately, for argument's sake, we may suppose ourselves to have made out the drift of them." The tenor of his answer is this : that it was by no means his custom, to trust his ordinary hearers with all the mysterious wonders, which he seemed to himself faintly to discern in Scripture, but that he always suggested those which he judged best for edifying : of which edification, one necessary groundwork would be, the securing the flock against the prevailing heresies.

(16.) But to proceed with our reasons for attributing, even to the

1 In Matt. Hom. xiv. § 12, t. iii. p. 630. D. 
allegorical school, a high respect for the literal sense. Clement $\$$ iii. 16. of Alexandria, Origen's predecessor, in discoursing on the two senses, (for it does not appear that it had occurred to him to distinguish the Moral from the Mystical; as Origen afterwards did, influenced perhaps by a desire to retain together with the Christian interpretation as much as he could of the morality which he admired in Philo ${ }^{1}$;) Clement, I say, among other very many psssages to the same effect, has one in which he refers to a Rabbinical tradition, remarkable at least for poetical force and beauty: that "when God took Moses to Himself, Joshua saw him in two forms; in one with angels, in the other on the mountains and among the ravines receiving sepulchral honours. This sight Joshua beheld from above, being lifted up in the Spirir, together with Caleb.... The drift of the history being, I suppose, to show that true knowledge does not belong to all, but some behold only the body of the Scriptures, the words and sentences, as it were the body of Moses: others see through to the meaning and the things signified by the words, making that Moses who is with the angels the object of their search. In fact, of those who called on the Lord Himself, the greater part said only, 'Son of David, have mercy on me ;' but some few acknowledged Him to be the Son of God, as Peter; whom also He blessed, because not flesh and blood had revealed to him the truth, but His Father which is in heaven: whereby Christ showed, that the perfect Christian recognises the Son of the Almighty, not by the flesh which was conceived and born, but by the very power of the Father."

Such passages as these lose their force, except we understand the letter of Scripture to have, in the opinion of these writers, a real and substantial meaning, as the bodies of our LORD and of Moses were real and substantial.

The same remark may be made on the only place, that I know of, in which Clement seems to come near the Origenian doctrine of the three significations. "The purport of the law," he says, "we must take, either as declaring to us some sign," (i.e. as it may 
\$ iii. 17. seem, some instance of Divine interference,) "or as establishing some commandment for right conversation, or as uttering an oracle in the manner of a prophecy." Here it is plain that the first or historical meaning is by no means slighted or annulled, since to it is ascribed the office of declaring signs from heaven.

(17.) Wemay proceed now to some citations from Origen, belonging to the second of the two classes specified above : cases, namely, in which he warns his hearers, more or less expressly, that the letter is by no means abolished. First, there is a remarkable fragment produced by the Martyr Pamphilus, which, on the whole, we may cite without scruple, notwithstanding the suspicions cast by St. Jerome and others, on the good faith or genuineness of the Apology for Origen, which went under Pamphilus's name. For it has no relation to the doctrine of the Holy Trinity, which was the occasion of the corruptions specified by Jerome ; and again, it has all the internal evidence, which can arise from agreement with Origen's ordinary interpretations. Thus then Pamphilus represents him as speaking of the evangelical narrative generally ${ }^{1}$. "Though these things have a spiritual meaning, yet the truth of the history being first established, the spiritual sense is to be taken as something over and above. For what if our Lord, in a spiritual sense, be always curing the blind, when $\mathrm{He}$ casts $\mathrm{His}$ light on minds blinded with ignorance: yet $\mathrm{He}$ did not the less at that time heal one corporally blind. And $\mathrm{He}$ is ever raising the dead: yet $\mathrm{He}$ did then really perform wonders of that kind also, as when He raised Jairus' daughter, and the widow's son, and Lazarus. And though at all times, when awakened by $\mathrm{His}$ disciples, He quiets the storms and whirlwinds of His Church ; yet it is unquestionable that those things also, which are related in the history, really took place on that occasion. This therefore is the only sound way of receiving the sense of Scripture; nor ought we to lend an ear to those who affirm, that He was born by Mary, not of Mary." In which last sentence the connection above noticed is obvious, between the historical sense and the Catholic doctrine.

The following are instances of detail, which prove how care1 A pol. pro Orig. p. 36 ; D. ad calc. Orig. Ed. Bened. t. iv. 
fully Origen carried this rule out in practice. In his commen- $\$$ iii. 17. tary on our LORD's future coming in the glory of His FATHER with His angels, he had spoken thus ", "Consider whether one may not say, that the Prophets in their sufferings of old bore an analogy to the $W_{O R D}$, which liad no form nor comeliness; but as the Son of Man cometh in the glory of His F Ftrier, so the Words abiding in the Prophets appear with Him, having become Angels, keeping up in a kind of due proportion the glory which appertains to them." This allusive exposition, modestly enough proposed, he follows up with words of caution. "These things we say, by no means slighting the doctrine of the second coming of the Sow of GoD, as it is more simply understood."

In the commentary on Genesis ${ }^{2}$, he answers the trite objections to the history of the ark, - how it could contain such a multitude of animals, and the like,- by a calculation as to its admeasurement, which supposes the account literally true; and on this, as a foundation, proceeds to build his allegorical exposition; thereby shewing that he did not spare trouble to avoid the mere allegory, wherever it seemed possible.

When he comes to the birth of Isaac, having quoted the wellknown passage from the Epistle to the Galatians, he asks ${ }^{3}$, "What then? was not Isaac born after the flesh? did not Sarah bear him? was not he circumcised? this very sport of his with Ishmael, did it not take place in the flesh? This is the remarkable point in the Apostle's exposition, that those thin's even, concerning which there can be no doubt of their having been done in the flesh, he affirms to be allegorical."

Having proposed a mystical interpretation of Abraham's marriage with Keturah and his second family, he adds an observation, which evinces that he did not think of annulling the historical sense $^{4}$. "If we remember the historical notices of the generations derived from her, we shall the more easily make out [the truth] about several nations mentioned in the Scripture, e.g.

\footnotetext{
${ }^{1}$ In Matt. xii. 30 ; tom. iii. 549. A.

${ }^{2}$ In Gen. Hom. 2. t, ii. p. 59-63.

${ }^{3}$ In Gen. Hom. 7, $§ 2$; t. ii.p. 78. C, D.

4 In Gen. Hom. 11, § 2 ; t. ii. p. 90. C.
} 
\$ iii. 18. where it is said that Moses married a daughter of Jethro the priest of Midian, which Midian we find was the son of Abraham by Keturah; whereby we learn that Moses's wife was of the seed of Abraham, and not an alien.... And the like you will find in the generations of Ishmael, which if you diligently look into, you will discover many points of history unperceived by the generality." Had it not been for these remarks coming in at the end, the whole tone of what he says about Keturah would lead one to suspect that he thought nothing of the literal sense : it is fair to conclude, therefore, that in other cases, where he is merely silent regarding it, he does by no means intend to disparage it.

(18.) Further, I observe that many of the passages, in which he seems at first positively and expressly to reject the historical sense, not only may, but in fairness must, be explained with very great mitigations. Sometimes he is only speaking by comparison, employing the same kind of figure as did the Prophet, when he wrote, "I will have mercy and not sacrifice." Thus in discoursing of the history of Isaac", he says, "As in the Lord there is nothing bodily, so in all these things take care to understand nothing bodily." Which words sound indeed like a plain denial, first of the reality of our LORD's Incarnation, secondly of the truth of the narrative concerning Isaac: yet it is evident in the same page ${ }^{2}$ that Origen was orthodox in the former respect; for he explains the real offering of the ram to represent the real suffering of CHRIST in the flesh, and the figurative offering of Isaac to represent the impassibility of the Divine WORD in the hour of crucifixion; and we have seen before that he specifies the history of Isaac as an instance of the allegory not impairing the truth of the letter. Who does not see then that the expression, " nothing bodily," must be taken in both clauses comparatively; "nothing merely outward and bodily ?" And in all candour the same qualification should be adopted in all similar cases, wherever the context, or his opinion otherwise known, does not oblige us to understand him as going further. For example, a little further on in Genesis, having to explain a phrase which seems

1 In Gen. Hom. viii. 10. t. ii. p. 83.

2 Ibid. $\$ 9$. 
tautological, he says ${ }^{1}$, "As I have often had occasion to observe, § iii. 19. in these things not histories are related, but mysteries are framed and put together:" evidently meaning not so much histories as mysteries : and implying that details, which might appear trifling or irrelevant, if considered only in themselves, are often amply accounted for, when you go to the secondary sense : a rule of sacred criticism, which is surely no way objectionable.

So again, in a fragment of a later part of his commentary on Genesis ${ }^{2}$, remarking on the fear expressed by the sons of Jacob, lest "Joseph should take them for bondsmen and their asses," he says, "It is improbable what is told of the sons of Jacob, that when they imagined themselves in so evil case they should have thought at all of their asses : except the expression is used allegorically." By which we may understand him not to deny the fact of their so speaking, but to account for their being directed to such expressions.

Also in the account of the destruction of $\mathrm{Ai}$ : "When the Jews read these things," says he ", "they make themselves cruel, and thirst after human blood," "putantes quia et sancti ita percusserunt eos qui habitabant $\mathrm{Ai}$ :" $i$. $e$. acting upon the idea that the saints did so and so; not as if the idea were a false one, but as if they reasoned wrongly upon it: for a sentence just before shews that this is one of the places to be expounded comparatively. $\mathrm{He}$ had said, "These ${ }^{4}$ things which follow, belong rather to the truth of the mystery than of the narrative."

(19.) It may be as well to note here, that the word $\mu$ ítos, or fabula, for applying which to certain Old Testament histories, Origen has been very sharply censured, both in ancient and in modern times, did by no means imply, in his acceptation of it, the falsehood of the history so denominated. For he uses it of the history of Lot and his daughters, which he calls " famosissima fabula s:" and yet it is clear from the whole context, that he believed the narration, and reasoned on it as real. We ought not, therefore, to be too much startled, when we find him using the word

1 In Gen. Hom. x. 4. t. ii. p. 88.

2 On c. 43 . 13. t. ii. p. 48 . E.

${ }^{3}$ In Jesu Nave Hom. viii. 7. t. ii. p. 417. B, C.

4 Ibid. \$ 6 .

${ }^{5}$ In Gen. Hom. v. 3. t. ii. p. 74. F. 
\$iii. 20. fables, concerning the history of Paradise, and of man before the Fall: though it cannot be denied, that on this particular point he has trespassed on the honour of the letter, and has taken occasion from the evident figure contained in certain phrases (such as "they heard the voice of GoD walking in the garden,") to affirm that the whole of what then took place is told only in symbol and parable: not (observe) denying that it conveys a real history, but that the said history is throughout written, as it were, in hieroglyplics. We are not of course called on to justify this proceeding, but it is desirable, on many accounts, to observe how far the error went.

(20.) We may just mention two other instances, on the former of which the accusers of Origen have very generally delighted to dwell. Both of them, however, a candid construction might perhaps solve on the principle now under consideration : viz. by supposing him rather to assert the superior importance, than the exclusive truth, of the mystical interpretation. They both occur in the process of harmonizing the Gospels : the former in the accounts of our Lond's going down to Galilee, in the early part of His ministry; the other in those of His anointing, whether that occurred once, twice, or three times.

In the first instance, which has been already quoted for another purpose, Origen's ${ }^{1}$ remark is, or appears to be (for there is an evident mutilation of the text:) "The very truth about these things must needs be stored up in the mystical exposition. If the discrepancy could not be solved, our faith concerning the Gospels must needs be impaired; as though they were either untrue, or uninspired, or as narratives not felicitously arranged." Then having stated the difficulty, and challenged the opponents of the mystical sense to solve it on any other hypothesis, he remarks in general on the Gospel narratives. "There are many other cases, in which minute inquiry into the apparent historical discrepancies of the four Gospels will lead to one or other of these results; either the inquirer, feeling a kind of giddiness, will give up the task of verifying them all in the strict sense, and will take up with one or other of them as it may happen; or, receiving the

\footnotetext{
1 In Joan. Comm. x. 2. t. iv. 162. B.
} 
whole four, will admit also that their truth does not lie in the \$iii. 20. outward and bodily characters wherein they are written."

To make his meaning plainer in this first clause, he puts the case $^{1}$ of four persons, favoured with visions, relating the same Divine interposition, but varying in such a minute circumstance as this; that the one saw the heavenly form sitting, the other standing; yet each with truth represents that which his own mind perceived. And considering that the doings of our Lord on earth were a series of Divine visions, "why," he says, " should we blame the Evangelists, for sometimes giving, as it were, each a turn of his own to the things done by our Lord, according to His miraculous and most inconceivable power; - sometimes interweaving into their narrative, in language taken from sensible things, what was revealed to them in a sense purely spiritual? Why should we blame them, though for edification's sake they sometimes transpose facts, relating a thing in such a connexion, as to make it seem to have happened in one place or time, when in fact it happened in another?" And then he makes the observation so severely censured. "It was their purpose, when circumstances allowed, to speak truth both spiritually and literally; but where both could not be, to prefer the Spirit to the letter, the spiritual truth being often preserved in what we may perhaps venture to call the literal and bodily falsehood."

In the other passage to be considered together with this ${ }^{2}$, he first states strongly the discrepancies of the literal sense, on the supposition that the several accounts of the woman anointing our Lord all relate to the same event ; and the consequent reasonableness of supposing that they related to several persons and events. Then he adds, in a way which is readily understood as implying that he is now come to the solution which himself prefers, "Perhaps some one rather bolder than ordinary will say, whether historically it were some one woman only who did an act of this kind, or whether you choose to suppose another, or a third; still, I say, first, that the main object of the Evangelists had respect to certain mysteries; secondly, that they were not so very anxious to relate according to historical truth, as to set forth

'Ibid. \$3, 4.

2 In Matt. Comm. Series, § 77. t. iii. p. 892. 3. 
\$ iii. 21. the mysteries which arose out of the history. On which account also they added certain discourses, suitable to, and in harmony with, the meaning of those mysteries."

(21.) Now concerning both these passages, let it not be thought mere partiality, if we construe them as affirming no more than a comparative exclusion of the literal meaning, a wish to enforce attention to the spirit, a deprecation of any thing like unbelief or scepticism on account of literal difficulties; answering very nearly to what is commonly said among ourselves, when objections are alleged against the Scriptures from supposed geological, astronomical, or other like incongruities, involved in their letter. They are objections, people say, of a wrong kind; it was not the object of the Scriptures to teach those matters. So here, comparatively speaking, we may understand this Father to say, "It was not the object of the Evangelists, simply to teach what happened to our LoRD on earth, but to teach it with a view to the heavenly and Divine truths concerning Him."

Just as of the history at the beginning of Exodus he says ${ }^{1}$, "These things are not written for us," ad historiam, "as mere matters of history: neither are we to suppose that the divine books are relating the doings of the Egyptians." It is evident from the context, that he here means "simply relating, for relating's sake:" that he is far from denying the verity of the letter, however he may seem to undervalue its importance. In such cases he may be regarded as endeavouring to account, not so much for any supposed untruth in a narrative, as for its being constructed in a way to make it look untrue.

A case very much in point would be the statements, undoubtedly conflicting at first sight, of the process which our Lond adopted for healing the blind men at the gate of Jericho. Origen would say, and has said, that such appearance of disagreement did not come of itself; that it was framed on purpose, to draw attention to the moral and mystery of the transaction; which, in every such case, will be found to be wonderfully brought

1 In Exod. i. § 5. t. iii. p. 131. E.

${ }^{2}$ Comm. in Matt. tom. 16. § 12. t. iii. 732. 
out, by a search wisely instituted to remove the historical diffi- \$ iii. 22 . culty.

(22.) A further mitigation of the censure due to him on this head may be derived from a remark of his Editor, De la Rue, who certainly was at least enough on his guard against an editor's partiality for his author. He states it as a strange, yet certain fact, that Origen perpetually confuses the literal interpretation of a passage as distinct from the mystical, with the literal sense of the words as distinct from the metaphorical ". "Quod pæne incredibile videtur, Origenem latuit discrimen quod literam inter et verborum literalem sensum intercedit." It would have been a more guarded, and perhaps a more correct manner of speaking, had he said only, that Origen sometimes writes as if he were not aware of this difference.

To make the thing plain by example: among other instances of the New Testament having, as well as the Law, a letter which killeth, Origen alleges ${ }^{2}$ the precepts of our Lord, "If any man hath a purse, let him take it, and he that hath no sword, let him sell his garment and buy one :" and " salute no man by the way ;"

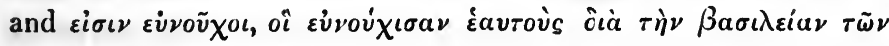

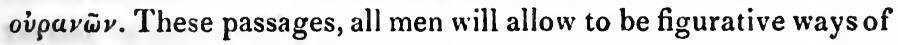
expressing a real precept. Now his oversight was, that he applied the same principle to passages, which seemed to him fraught with historical difficulties : as in the account of Sarah and Abimelech, of Isaac andRebecca, and of the midwives of Egypt ; where his expressions are such as these: "If any one chuse to understand this merely according to the letter, he ought to seek his hearers rather among Jews than among Christians "," and "think you that these are no better than tales, and that the HoLY GHost is merely relating histories"?" and "if we take what is written concerning the midwives according to the historical narrative, it appears that such and such a thing cannot stand ${ }^{5}$." Yet if the several histories be examined, it will be seen that to deny the truth of the fact is by no means necessary to his argument : the ends of

${ }^{1}$ Pref. in t. ii. p. xvii. $\quad{ }^{2}$ Comm. in Matt. t. xv. 2. tom. iii. 653.

${ }^{3}$ In Gen. Hom. vi. i. t. ii. p. 76, D. ${ }^{4}$ In Gen. Hom. x. 2. t. ii. p. 87. F.

5 In Exod. Hom. ii. 1. t. ii. p. 133. E.

VoL. VI. -89 . 
iii. 23. which are sufficiently answered, by supposing him to deny, that this or that turn of expression was designed to be taken literally. Nay, even according to his unfriendly editor's statement, if he were not sufficiently aware of the distinction between phrases mystical and merely metaphorical, he was very likely to mean the milder assertion, i. e. that the figurative expression was designedly made paradoxical, when he seems to advance the stronger, i. e. that it wanted the foundation of literal truth.

For these and other like reasons, even though the school of Origen were a fair specimen of the old ecclesiastical interpretation, it would not follow that that interpretation could be charged with denying the letter, except in rare and difficult cases, where, as he has himself said, we miss altogether the historical meaning: " defectum patitur historialis intelligentia "."

(23.) But the matter is thrown out of all doubt, when we add to what has been said, the fact that the Church has virtually disowned all responsibility for the peculiar opinions of this renowned Father; partly by the sentence of a general Council, partly by the deliberate judgment of some of her chief lights of later days. It is in some respects unfortunate, that that portion of the fifth general Council, which contained the proceedings against those called Origenists, has not come down to our time : but in the decisions of the Council, it is to be observed, that no mention is made of the denial of the letter of Scripture, as one of the supposed errors of Origen. The errors which were maintained in his name,-most of which may be described as mere conjectures, expressed as conjectures by him, and afterwards advanced to the rank of tenets, philosophical or theological, by speculators who made the most of so high a sanction; such as the pre-existence of souls, the manner in which the merits of the Redeemer may be applied to angelic natures, the supposed universal renovation, and the like:-these errors are enumerated in fifteen articles ${ }^{2}$; but the alleged abandonment of the literal sense of the Bible does not appear among them. However, the whole affair, coming as it does at the conclusion of three centuries of

${ }^{1}$ Hom. in Gen. vii. 5, t. ii. 80. B.

2 Vid. Harduin. Concil. t. ii. p. 286-288. 
dispute, shows that there was no such blind deference to $\$$ iii. 24 . his authority, then or at any former time, as may render the Church liable, on his account, to the charge of disparaging the letter of Holy Scripture.

(24.) The opinions of the most celebrated Fathers are collected by the Benedictine editor, in his preface to the second volume ${ }^{1}$. Such as the sentiment of St. Basil, in a passage quoted above 2: "I know the laws of allegory, though not by my own invention, yet by acquaintance with the labours of others: according to which, they who will not receive the ordinary sense of what is written, in the account of the Creation for example, affirm water not to mean water, but some other nature; and plants and fishes they expound at their own pleasure; and the formation of creeping things, and of wild beasts, they pervert according to inventions of their own, much like those who profess to interpret dreams." St. Chrysostom again, as cited by De la Rue, remarks, that the geographical situation of Paradise, " eastward in Eden," may have been purposely inserted by the Sacred Spirit, " to prevent those who are inclined to useless talk from deceiving the ears of the simple, by stating that Paradise is not in earth but in heaven, or putting about any other the like mythological dreams "."

It is to be observed, that neither these Fathers, nor St. Augustin whê: he expresses similar sentiments, make any mention of the name of Origen : although Augustin, in more than one passage, condemns him by name, for the same doctrinal errors which were afterwards censured in the second Council of Constantinople. But they seem to have observed a kind of tenderness towards him, which makes their express warnings the more striking, and at the same time leaves room to suppose, that, according to the view which has been taken above, they might regard him as rather leading others to deny the letter of the Bible, than as being himself guilty of such an error on any large scale.

St. Jerome and Epiphanius, as is well known, were less scrupulous in their attacks on Origen, probably (at least in part) as living among persons who were continually pushing his specu-

\footnotetext{
${ }^{1}$ P. xxiii. ${ }^{2}$ Hexaëm. Hon. ix. $\$$ i. $\quad{ }^{3}$ In Gen. Ilom. xiii. t. i. p. 80
} 
$\S$ iii. 25. lations into heresy. Nothing can be more express than their protests against him ', addressed to John, Patriarch of Jerusalem, for turning the Scriptures into mere allegory, as far as the history before the fall was concerned.

Yet, as is often sarcastically alleged by the detractors of the Ancients, not even Origen himself abounds more in mystical and figurative interpretations than did these two distinguished Fathers, St. Jerome and St. Augustin. Are we to conclude that such men wrote at random, and did not know their own mind on such a very serious point, as a rule of interpretation extending through the whole Scriptures? Must we not rather conclude, that their censure of Origen as an allegorist, which, generally speaking, we may accept as the censure of the Church, went thus far, and no further? viz. to blame him for supposing that the literal sense would ever entirely vanish, however impossible it may be for us at times to ascertain it, and however inferior it may generally or always be, in comparison with the mystical sense: to blame him, again, for objecting to it, as he sometimes occasionally does, (contrary however to his own declared rule) on grounds not flowing from the analogy of the faith as held and interpreted by the Church, but such as we should call rationalistic ; such as a thing being to our minds inconsistent with the majesty of the Deity. Lastly, and perhaps principally, we may understand them to blame him for too great boldness and luxuriance, in advancing interpretations, not in any way received by tradition, but devised by his own thoughts. But not in any sense can they be said to condemn him simply for maintaining the double sense of the old Scriptures, in the very way, wherein, as we have seen, the whole body of Christian writers, from St. Barnabas and St. Clement downwards, had maintained it.

(25.) And this is true not only of Jerome and Augustin, whose love for allegory is well known, but also of the other two great names, Basil and Chrysostom, who are comparatively remarkable for reserve in such interpretations. Yet Basil, on the Psalms, repeatedly refers to our Lond expressions which would be com-

1 Epiph. Epist. ad Joan. Ierosolym. ap Hieron. t. i. 247, \&c. ; Ed. Vallars. 1766 ; Hieron. contra Joan. Ierosol. § 7 ; t. ii. 413. 
monly interpreted of the Psalmist only. And Chrysostom (to say §iii. 25, nothing of his practice) in the very passage which is cited from him as so decidedly condemning Origen, points out the necessity of understanding all things $\theta \varepsilon o \tau \rho \varepsilon \pi \tilde{\omega} s^{1}$. " " The Lord Gop planted Paradise.' Consider, beloved ; if we do not understand these things in a sense becoming the Ammigry, we shall needs be carried over a deep precipice. For what can they say concerning this word, 'planted,' who dare to take all the words spoken concerning the DeITy in a human sense? Did God need tools and husbandry, and other such process, to adorn Paradise? Gov forbid. . . . Against this," as against the mere allegory, "let us stop our ears, and follow the rule of the Scripture. And when thou hearest, 'GoD planted a garden in the East,' take care to conceive of the word 'planted' in a divine sense concerning God, that $\mathrm{He}$ gave order for such a thing to be; but as to the next word, believe thou that Paradise really was formed, and in that place where the Scripture hath pointed it out. For not to believe the things set down in the divine Scripture, but rather to introduce other things of one's own mind, must, I conceive, bring extreme danger to those who venture on such a proceeding." On the other hand, in his exposition of the 47th Psalm ", he says, speaking of the verse, " $O$ clap your hands, all ye people;" "With reason might one take this Psalm according to the mystical sense, rising above the literal meaning. For though it take its beginning and prelude from things sensible, yet it guides the hearer to the things which are merely spiritual. For, as I have said before, so now I say again, some things we must take as they are said, some contrary to the letter; $e . g$. when it is said, the wolf shall lie down with the lamb. Some in both senses; as the sacrifice of Abraham, and the first paschal lamb." Compare this passage with the former, and it will be plain that while St. Chrysostom was earnest in condemning the too free speculations of a later age, there was nothing in his principles contrary to the mode of exposition, which, as we have seen, was adopted by the Fathers before Origen.

On the whole, we may assume that the Mysticism of the ancient

\footnotetext{
${ }^{1}$ Hom. 13, in Gen. t. i. p. 80, lin. 29, Ed. Savile.

2 t. i. $652,16$.
} 
§iv. 1. Church (whatever might be said of some individuals) was very far from interfering with the truth of the history. The next point will be to show, that neither did it interfere with moral truth, i. e. it did not, by prophetical exposition of certain questionable parts of the Patriarchs' conduct, annul or confound the judgment of the well informed moral sense, as to the rectitude of such conduct. This however must be made matter of separate investigation.

\section{§iv.-Mysticism as applied to the Moral Difficulties of} Scripture.

It has been endeavoured in the former sections, first, to shew distinctly what is meant, when the Fathers are charged with Mysticism, and to point out by example the need of extreme caution and reverence, whenever we approach that subject. Secondly, granting the fact that they are, generally speaking, Mystics, at least in the interpretation of Scripture, (for to that in its present stage the inquiry is limited) a reason was however adduced for believing that they were not so at random, nor in mere blind obedience to the literary fashion of the day. The reason is this, that we find them, with few and rare exceptions, careful to limit their mystical expositions, so as not to destroy the historical and literal meaning. The exceptions, chiefly drawn from the Alexandrian school, were shortly considered, and appeared in themselves less formidable than they are sometimes represented : it appeared moreover, that whatever their amount, they so far tend to strengthen our argument, as they occasioned an anxious disavowal of the mere allegory, on the part of St. Basil, St. Augustin, and others, who had the best claim to be regarded as representing the whole Church. Their verdict is correctly reported in the following passages from Cyril of Alexandria ${ }^{1}$.

"In the inspired writings those who shrink from the literal and historical meaning as unsound, are chargeable in effect with something very like shrinking from the only process, which can enable them to understand the things therein set down. For

${ }^{1}$ In Esai. lib. i. 4 ; t. i. p. 113. 
the investigation of them in the mystical way is indeed noble §iv. 2. and profitable; it tends to enlighten throughly the eye of the mind, and greatly to advance us in good understanding: nevertheless, as often as any historical fact is introduced to us by the Scriptures, then surely, if ever, it becomes us to trace out the profitable use of the history, that the divine Scripture may do its work, saving and helping us in all ways." This was in agreement with the rule, which he had laid down for himself in the beginning of his commentary on the Pentateuch ". "Our exposition will be useful, if we first consider the facts, as they really took place, and make part of history; and having as we may completed that view, if we then new-mould our statement, passing from the type and shadow to the clear account of the inward signification; our discourse having all the way a bearing on the Mystery of $\mathrm{CHRIST}_{\mathrm{H}}$ and tending to Him as its limit ; since it is an unquestioned truth, that Christ is the end of the Law and the Prophets."

Such had been the line of interpretation, which the Fathers of the first age, by a kind of sacred instinct, adopted from the beginning: and in no other did those of the fourth and fifth ages acquiesce, after full examination, and abundant opportunity of judging how far it was likely to be abused.

(2.) We have now to consider this mystical method in its application to one class of texts in particular; those portions, namely, of the Old Testament history, which record actions of questionable morality on the part of God's favoured servants. So it is, that in modern times, even among those who appear truly to reverence the Bible, there is commonly adopted, in regard of these startling passages, a tone of explanation and remark, very different from that which prevailed in the early ages of the Church. It seems desirable, for many reasons, to ascertain the amount of that difference, and how it may be best accounted for. We may find perhaps that the patristical mode of interpretation, rightly understood, interferes as little with moral as it before was found to interfere with historical truth; and the whole discussion may tend to convince us, that on this, as on

1 T. i. p. 2. C. ed. Aubert. Paris. 1638. 
§iv. 3, 4. most theological subjects, we have much more to learn from the Fathers, than to apologize for in them.

(3.) That the Fathers, deeply as they were versed in every part of the inspired writings, were fully aware of this kind of Scripture difficulty, one might be certain beforehand, on considering that it is a difficulty which occurs to every person, even to children, perusing the Old Testament with an ordinary degree of attention. Nor do we find commonly in their writings any desire to evade the subject, or to draw off attention from it. There were controversies indeed in the four first ages, which would have forced it continually on their thoughts as polemical writers; such as that with the Marcionites first, and afterwards with the Manichæans, who used the startling parts of the sacred history, as proofs that the Old Testament came from an evil, or at least from an imperfect, Being: or again, that which they had constantly to maintain with the Pagan Philosophers, who, as appears from Celsus and Julian, were not slow to employ this topic against Christians and Jews alike: but the remarkable thing is, that the same narrations are produced, and discussed without reserve, in their practical and popular writings also, their pastoral letters to individuals, and their homilies ad populum. There seems no desire on their part to withdraw these things from common observation, such as we now find not unfrequently, even among those who on other grounds would encourage the freest discussion and circulation of the Scriptures. Their reserve, their secret discipline, so perplexing to many in our days, did not extend to these things.

(4.) Neither do we find that even those, who took the greatest liberties in allegorizing, who came nearest in some instances to the denial of the letter,-not even that such as Origen,--thought themselves warranted in getting rid of the moral difficulty, arising from the places in question, by resorting to the mere allegory. They did so, or appeared much inclined to do so, where the literal statement seemed physically or historically impossible: occasionally also where it seemed very trifling or frivolous; but it is not so easy to meet with a passage, where the same solution is applied to any narrative, merely on the ground of its apparent 
immorality; which yet, with our modern notions, would seem to be the most tempting ground of all.

This remark is made with all the hesitation, which becomes one who ventures on a sweeping statement after a very limited induction. But should it be found on the whole correct, it is surely a very considerable circumstance, and may help to convince us that these early theologians knew well what they were about, and did not use their solutions at random, just as difficulties happened to press, or ingenious answers came to hand. Celsus, as it appears from Origen ', charged the apologists of the Bible with this very artifice; "that the more plausible among them, being ashamed of certain portions of their sacred books, take refuge in the allegorical meaning:" and among other instances from the Book of Genesis he alleged the disputes of Jacob and Esau, the conduct of Rebecca, the histories of Lot and of Jacob's family. Origen's answer in effect comes to this ${ }^{2}$ : he disavows all intention of denying the fact in such histories as those above mentioned. "In many instances," says he, "the word [of God], hath made use of real transactions, and recorded them so as to exhibit things greater, covertly indicated, such as are" (among others) "the marriages and various connections of the righteous men [of old]." Farther on he contrasts the patriarchal narrative with the foul and revolting fictions of the Greek mythology; which, as he observes, were indeed full of shamefulness, taken in their first acceptation, relating as they did to their very gods and the sons of their gods; and having enforced this by the virtual confession of those Greek philosophers, such as Chrysippus, who had laboured to make out the symbolical purport of their fables, he proceeds as follows : "Because of these things-because of such fables as these and others innumerable, we for our part are unwilling to go so far as even in name to call the Supreme God (e.g.) Jupiter; or the Sun, Apollo; or the Moon, Diana. But exercising pure religion towards the Creator, and concerning His works, which are very good, using none but good and auspicious words, not even by a name do we pollute the things of God: accepting what Plato says in the Philæbus:

${ }^{1}$ Contr. Celsum, iv. 48, 43, 45.

${ }^{2}$ Ibid. $\$ 44$; t. p. 537 , B.

$\S$ iv. 4. 
§iv. 5. ' so great,' says he, 'is the dread which I feel concerning the names of the gods.' We also, of a truth, are full of dread concerning the Name of our GoD and His good creatures, to that degree, that never could we admit, even under pretence of symbolical language, any tale or fable which tends to the corruption of the young 1." The argument of this passage may seem to require explanation. It may be briefly stated thus. "The fact is well known that believers in the Bible decline even the metaphorical use of the names of the heathen gods; so great is their abhorrence of the impious immoral stories with which those names are associated; judge you then whether they are likely, under any pretence of allegory, to admit, as vehicles of their own doctrines, stories really base and immoral."

From all this it is sufficiently manifest, that the line of defence taken by Origen, and $a$ fortiori by those who were less prone to allegory, would be, to vindicate on their own grounds the moral tendencies of the several statements objected to, assuming their historical truth. How far such his vindications were or were not independent of the allegorical meaning, which he also asserted, and for which he argues at large in this very passage, is another question, to be considered hereafter in its place.

(5.) Now there is a strong presumption, at first setting out, against the supposition that the Fathers dealt lightly with this class of Scripture difficulties, that they trifled with them, or treated them in a way to disturb men's notions of morality. For it is a certain fact, that the early Christian moralists, whether nominally attached to any particular school or no, were none of them in any sense Epicureans nor utilitarians. They all held, expressly or by instinct, a moral sense in the heart of man, and its correlative, a real difference of right and wrong in human conduct, independent of all results.

It was partly on this ground that they preferred to all others the schools of Pythagoras and Plato, a preference which is fully stated and accounted for at large by St. Augustin, in his eighth Book on the City of God. A few passages may be given, as tending to show what line Christian philosophers (for in their name generally St. Augustin is speaking, and not of his own

1 Contr. Celsum, p. 48, t. i. p. 540. 
private opinions) would be likely to pursue on delicate points §iv. 5. of casuistry.

With regard then to the moral sense: "Far be it from us," he exclaims", "to think of comparing the Platonists with those, who make the bodily senses the standard of truth, and pronounce them, faithless and deceitful as they are, the rule and measure of all propositions ; as do the Epicureans and all of the like sort: as the very Stoics also themselves, who in their fond affection for Dialectic, as they term it, i. e. for the art of ingenious argumentation, have imagined that even it might be best derived, ultimately, from the bodily senses; affirming that from no other source does the mind conceive the notions which they call primary (ideas, i.e. of certain things which their theory goes on to define particularly), and from which is deduced and framed the whole process of learning and of teaching ... But the Platonists (deservedly therefore preferred by us) distinguish what the mind beholds from what strikes on the bodily senses; neither denying to the senses what they are capable of, nor assigning to them more than they will bear. But the light of the mind, whereby all things are to be learned, they affirmed to be no other than the God by whom all things were made."

A little further on, he writes as follows: (The passage is here quoted, not so much for the astonishing depths which it discloses of what may be called Christian Philosophy, as because the author states himself to be speaking not his own private sentiments, but the feeling, avowed or instinctive, of the whole Church $^{2}$.) "So far as the Platonists agree with us, concerning one God, the Author of this universe, who is not only above all bodies, Himself incorporeal, but also above all souls, Himself incorruptible, our Source, our Light, our Good-so far we prefer them to all others. What if any Christian, ignorant of their literature, use not their terms in disputation, (how should he, since he never learned them ?) what if he neither call that branch Physics, which treats of inquiry into things natural ; nor that Logic, which analyses the process whereby truth may be discerned; nor that Ethics which treats of conduct, - of the chief good to be sought, and the chief evil to be

\footnotetext{
${ }^{1}$ De Civ. Dei, viii. 7. $\quad{ }^{2}$ Ibid. cap. 10.
} 
§iv. 6. avoided ? he knows nevertheless that all three are from the one true and most bountiful God; both our nature, whereby we are formed according to His image; and the doctrine, whereby we may know both $\mathrm{Him}$ and ourselves; and the grace, whereby, cleaving to Him, we may be perfectly blessed. Behold here the cause of the preference we give to the Platonists: that while other philosophers have worn out their toil and their talents in searching out the causes of things, the rules of learning and of life; these alone, acknowledging God, have found the cause of the world as it is, the light of all truth that may be attained, the fountain of all bliss that may be tasted. Be these philosophers then Platonists, or whoever else of whatever nation, who think thus of God, they think with us."

(6.) In Origen we have repeated disavowals of the principles of the other sects, and repeated acknowledgments of the remarkable coincidence between the principles of Plato's morality, and those which the Gospel divinely sanctions. Of the former class, the following is a specimen ${ }^{1}$ : "The Christians are likened by Celsus to one, who professing to cure bodily sickness, should withdraw men from skilful physicians, for fear of having their own ignorance detected. But who, I ask, are these physicians, from whom we thus withdraw the simple? ... Suppose it, for example, to be the philosophy of Epicurus, and of those who belong to his school, . . . what do we that is not most reasonable, liberating men from that evil disease, the result of the treatment of these favourite physicians of Celsus: I mean the denial of Providence, and recommendation of pleasure as the chief good? Or what again, if we draw off our disciples from those other physician-philosophers who are called Peripatetics; denying as they do all providence over mankind, all relation between GoD and man? what is this but an exercise of piety on our part, and a real mental cure to those whom we influence?... Grant, again, that there are others, whom we separate from the physicians of the Stoical class, the maintainers of a corruptible God of a bodily and perishable substance : . . . in this case too, can any one deny that we shall be delivering those who will believe us

1 In Cels. iii. 75. 
from many evils, and introducing them to the doctrine of true piety, the doctrine of resignation to the CREATOR of the world?"

To this rejection of all other theories, he elsewhere adds express approbation of Plato's, of which perhaps no instance can be adduced more remarkable than this: "Let those who are able to understand receive the instruction of ancient and wise men; of Plato especially, the son of Ariston; let us hear what he says in a certain letter concerning the chief good: let us attend to him, affirming, "the first and chiefest good can in nowise be uttered in words, but is first generated by long habit, and then on a sudden, as though by fire, starting into a blaze, is kindled like a light in the soul.' Which words we also hearing, assent unto them as excellently spoken : for it was GoD Himself who revealed to them those things, and whatsoever else has been rightly taught by them."

(7.) To the same purpose may be alleged those passages in Clement of Alexandria, peculiarly startling to those whose views are framed upon the phraseology of modern theologians, wherein he speaks of the old Pagans being in a certain sense justified by philosophy ${ }^{1}$; of its being necessary to them for righteousness before the coming of our Lond ; of its constituting one out of many ways or gates of righteousness ${ }^{2}$, whereby men, according to Gon's manifold goodness, might be and were variously led towards the royal way and gate. These and similar high expressions relate especially to the Platonic morals : although it is true that in his general commendations of philosophy he wished to be understood as adopting an eclectic process : "I mean not," says he, "the Stoical or the Platonic alone, nor yet that of Epicurus, nor of Aristotle; but whatsoever sayings may be found in each of those sects, rightly inculcating righteousness with religious consideration, those taken all together by way of selection I terin philosophy ${ }^{3}$." This eclecticism may very well stand with an exclusive preference of Plato's doctrine, as to the unchangeable nature of moral good, arising out of the unchangeable attributes of God; a doctrine with which Clement every where in-

1 Strom. i. 99 ; vi. 44.

2 Ibid. i. 38 ; vi. 45.

3 Ibid. i. 73. 
$\S$ iv. 8. dicates his concurrence : $e$. g. where he calls Justice natural, and especially in that remarkable place which conveys his exposition of the critical word Justification " " "You have been justified," " says the Apostle, " ' in the name of the Lord ;' you have been made by $\mathrm{Him}$, so to speak, righteous, as $\mathrm{He}$ is righteous ; and in the greatest possible measure, according to your capacity, you have been blended and united with the Holy Spirit of God." This sentence clearly evinces, that when he spoke of philosophy justifying the heathen, he was far from any thought of its meriting for them, in the strict sense of the word, forgiveness of sins : he was speaking of inherent goodness, and that, he affirmed, philosophy gave them, so far as they may have really practised it, by the secret aid of God's good SPIRIT, and so far as they may have become, accordingly, conformed to GoD's image ; an idea which evidently applies to the Platonist alone, among heathen schools of morality.

Such is, what has sometimes been called in scorn, the Platonism of the early Church; the allegation implied in that name being about as correct, as if one should say, the sun's light was borrowed from the reflection of the moon in the water. The passages have been adduced, not to prove the fact, for that is allowed on all hands; but as putting strongly before the mind the sort of view, which the ecclesiastical writers were likely to take of those narratives of Holy Writ, which we may call, in one sense, painfully perplexing. We see that they could not consistently explain them by any view, however enlarged, of expediency, a greater good resulting in the end; they must either leave the several difficulties as they found them, or make them out in some way positively consistent with GoD's eternal law.

(8.) We are far, however, from being left to antecedent probabilities on this head. St. Augustin, in his treatise against Faustus the Manichæan, has left us an elaborate statement of the principle on which, as he conceived, objections of the kind now in question are to be met, accompanied with many exemplifications. The Manichæans, as is well-known, affirmed the Old Testament to be the work of the Evil Principle; and one of their main arguments was

\footnotetext{
${ }^{1}$ Strom. vii. 87.
} 
grounded on the distressing parts of the Old Testament history. \$ iv. 8. Indeed the similarity is wonderful between the blasphemies of Faustus, as they are recited by St. Augustin, and those of many modern unbelievers : whether the replies of St. Augustin agree as well with those most in favour among modern vindicators of Scripture, is another question; of which more will be said presently.

He addresses himself to the inquiry with all the religious care, which might be expected from his deep reverence and affection for the Bible : stating himself, in the outset, to have in view the case, not so much of the Manichæans,-whose theology, as well as their moral conduct, proved that they could not adduce such objections in earnest, - as of others, who, without any vain teaching of their's, found in themselves disturbing thoughts, on comparing the life of the Prophets in the Old Testament with the life of the Apostles in the New. "That we may not," says he ", "proceed rashly in our moral judgment of these matters, we shall do well first to consider, what is sin : then to look into the deeds of the Saints registered in the divine books, that if in any instances we find even them to have sinned, we may ascertain, as diligently as we can, for what good end their sins also were set down and committed to memory. Next, in whatsoever cases we find what appears sin to the foolish or ill-disposed, not being such, yet not having in it any obvious example of goodness : we shall have to consider for what cause these things found a place in those Scriptures, which our faith tells us were written for our [soul's] health, to control us in this life, and obtain for us that which is to come. Lastly, whatsoever among the deeds of the Saints shine forth as lessons of righteousness, no man, even among the simple and ignorant, doubts the propriety of recording these. Of the two former classes, then, there may be a question; first, those which may seem to be recorded idly, not having any goodness found in them, yet not being sins; secondly, those, the relation of which may appear even pernicious, their sinfulness being undeniable, and they not unlikely to be drawn into precedent. In which latter kind again we may observe a further distinction. For some of these actions are uncensured in the Scripture itself, and

${ }^{1}$ Contr. Faust. lib. xxii. 26. 
\$ iv. 9, 10. may, therefore, by some be imagined no $\sin$ at all; others are indeed reproved in the Bible, yet may be committed with an hope of easy pardon, being such as are found even in those holy men."

(9.) A fairer or fuller statement of the case could hardly be given in the same number of words. Observe now how absolutely he lays down the doctrine of immutable morality, as the standard whereby to try the conduct of the Saints, no less than the ordinary conduct of ordinary men. " $\mathrm{Sin}^{1}$," he proceeds, " is something done, said, or desired contrary to the eternal law. By the eternal law I mean the Divine reason or Will of GoD, commanding the preservation, forbidding the disturbance, of the natural order of things." Presently after he applies this standard to the several cases enumerated by Faustus, such as the polygamy of Abraham and Jacob ; Abraham's conduct when with Sarah in Egypt ; the histories of Lot, Judah, David, and others ; the sanguinary wars and executions of Moses. And how uncompromising his casuistry was, we may see in the treatise De Mendacio: where he denies the lawfulness of any kind of lie, even for the saving of a man's life or soul, and maintains that all the cases alledged from the Old Testament in excuse or commendation of those who take such liberties, either had not the nature of lies, or are proposed as warnings, not as examples to mankind.

Such being in general the strictness of the Fathers' morality, it is nevertheless undeniable, that they treat the passages in question-St. Augustin himself, the asserter of a rule so inflexible, treats them-in a tone at which modern ears are apt to be startled : positively and unreservedly praising some things, which the men of this age either boldly censure, or condescendingly try to excuse, or at best shrink from discussing, as they would from 2 the touch of a hot iron: and using much doubt and reserve in their censure of others, which to us are apt to seem clear and unquestionable cases of gross immorality.

(10.) Now with regard to the former class-the cases where the approbation of the Fathers is more positive than we should venture on,-it perhaps will be found that they generally spoke from

${ }^{1}$ Contr. Faust. xxii. 27. 
a strong impression (which might or might not be well-grounded $\$$ iv. 10. in the particular case) that the person was acting by express command, or secret but sure inspiration, of A Lмighty God. The most signal instance of the kind is Abraham's sacrifice of his son: the command for which is too plainly set down in the Old Testament, and the praise of it in the New too marked and emphatical, to admit of its being called in question by any believer; but it is not always felt how far the principle of it extends:- that to it, as to the head of a class, may be referred very many of the passages which startle men, by representing God's favoured servants as acting with apparent cruelty and harshness. The Fathers deeply felt this : they felt that where GoD had plainly spoken, the justifications and arguments of men were out of place : nor did they doubt His having means to make His own voice so clear to His servants, that they need not fear its coming from any Spirit but His. And therefore St. Augustin, defending God's people against the charge of wronging the Egyptians, felt that he had said enough for them, if he brought them under the same category with Abraham : i.e. if he showec that they as well as Abraham had an express command from God. And this the very Manichæans must allow; for even Faustus, in general so unsparing, had not dared to insert the sacrifice of Isaac in his charges against the Patriarchs; probably because it would have been too offensive, so clear was the verdict of exceeding praise bestowed on that act in the New Testament. St. Augustin's reasoning is thus worded ${ }^{1}$ :-

"Some acts there are which the Eternal Lord . . . has set before men as in a kind of middle station, so that our taking them on ourselves would be justly blamed for presumption, but in fulfilling them, commanded, we earn the praise of obedience. So much difference does it make in the natural place and station of things, not only who is acting, and what is done, but also under whose authority. Abraham, had he sacrificed his son of his own accord, what would he have shown himself, but fearfully profane and detestable? What, when he did so at Gon's bidding, but full of all faith and devotion?" (Elsewhere ${ }^{2}$, in comparing

${ }^{1}$ Contr. Faust. xxii. 73.

2 Quæst. in Jud. xlix. 4. t. iii. p. i. 456. D.

voL. VI. -89 . 
§iv. 10. Abraham's act with Jepltha's, he had made this the leading difference: that the one, being bidden, offered his son; the other did what was forbidden by the law of Moses, and not enjoined on him by any special command.) . . . . "Wherefore, if in the slaughter of a son the voluntary act would be accursed, but the dutiful obeying God's voice not only unblameable but glorious ; why, O Faustus, blamest thou Moses, for having spoiled the Egyptians? If thine anger is moved by the apparent dishonesty, supposing the act human, let thy fear be also moved by the Divine authority of Him who enjoined it. Or, art thou prepared to blame God Himself for willing such things to be done? Then 'get thee behind me, Satan, for thou savourest not the things which be of God, but those which be of men." "

He proceeds to apply the same principle to the wars of Moses and Joshua, and the destruction of the Canaanites " - "The wars wrought by Moses we need not admire or shudder at, for in them he followed the Divine command: it was not cruelty, but obedience $\ldots .^{2}$ Why then rush we into daring reproaches, I would I could say, of men only, and not of GoD? What, if the ministers and dispensers of the Old Testament, who were also harbingers of the New, did their office by slaying sinners; while those ministers of the New, being also expositors of the Old, did theirs by dying under the hands of sinners? Yet both did their office to God-to Him who teaches that at divers but convenient seasons, from Him temporal goods must be sought, and for Him they are to be despised : by Him temporal chastisements are enjoined, and for Him they ought to be endured." So Theodoret, speaking of the slaughter of Agag by Samuel" : "He slew him as Phinehas did Zimri : for whatever GoD commands is religious." And Cyril, with no less simplicity and piety ${ }^{4}$ : "We ought unhesitatingly, attributing rectitude to the verdict pronounced in Heaven, to keep ourselves from all thoughts of cavil, and hasten to accomplish what is bidden, though it be something not very agreeable to our own understandings. $E$. g. Saul spared Agag : . . . . whereby he offends GoD, and that greatly; for he dealt gently

${ }^{1}$ Contr. Faust. xxii. 74.

${ }^{3}$ In 1 Reg. qu, 34. t. i. 379. ed. Schulze.
2 Ibid. $\$ 79$.

${ }^{4}$ Comm. in Hos. t. iii. 13. C. 
with him who was appointed to die ; his conduct being all one as if he had proclaimed in so many words, that God had passed an § iv. 11. unjust sentence on Agag."

(11.) To many persons, reading their Bibles with unprejudiced and simple minds, it may seem as if on this point we were multiplying unnecessary quotations. "Obey my voice," is to them, and they feel that it must ever have been to God's Saints, all in all, without further inquiry. But it seemed desirable to give full expression to the patristical view of cases like that of Abraham's sacrifice, for the sake of comparing it with a notion which seems to find favour with many in our days. Antiquity was content, when once it discerned a plain injunction from above: but the restless ingenuity of this age will not permit us heartily to acquiesce in the praises even of such as Abralıam, except under cover of a certain theory of accommodation. Human sacrifices, we are told, and particularly the sacrifice of children by their parents, were notoriously practised by the nations of Canaan : Gop had not yet declared His abhorrence of such sacrifices : they were practised in that time and country as the most solemn rite of religion : therefore, whatever Abraham's feelings might be, his conscience was not startled at the command to offer his sonit was not yet an enlightened conseience-it partook of the barbarity of his time and country : allow for that, and Christians may iontemplate the sacrifice of Isaac with edification, but without such allowance it will be a stumbling-block.

In like manner, the destruction of the Canaanites, the slaughter of the Midianitish women by Moses, of the Amalekites and Agag by Saul and Samuel, were not blameable in those times, because in those times " the laws of war, if so they may be called, were so thoroughly barbarous, that no amount of slaughter committed against enemies was likely to shock the feelings of any one." Samuel, in short, was a half-civilized person, and therefore might be justified in putting Agag to death, in obedience to the plain command of GOD; but " to men in an advanced state of moral knowledge and feeling, the command to perpetrate such general slaughter .... would be so revolting, that they could not and ought not to think that GoD could possibly be the author of it." 
§iv. 12, 13. (12.) Now, not to dwell here on the fact, that the iniquity of the Amorites, in Abraham's time, was declared to be not yet full, and that the book of Deuteronomy seems to speak of their burning their sons and their daughters in the fire to their gods, as the crowning act of that iniquity ; considerations which would seem to throw no small doubt on the statement that human sacrifices were usual in Canaan in Abraham's time; neither would that doubt at once be removed by the mention of such sacrifices as practised by the Moabites many generations after :- not to insist on the remonstrance of Elisha, "Wouldest thou destroy those whom thou hast made captive by thy sword and by thy bow?" as an indication that the then received "laws of war" were not in all cases altogether so barbarous as the above argument requires :- omitting for the present objections of the historical sort, and only just noticing the obvious remark, that the higher and gentler a person's general tone of moral feeling, the less likely, one should think, would he be to be hurt and corrupted by a command to execute vengeance in some isolated case, however unsparingly ; -on granting which, the whole speculation vanishes :-passing over these and other considerations, the one thing now to be observed is, the striking contrast between the tone and manner of St. Augustin, and of the modern apology for the Bible : how completely the one mounts above, the other defers to, the natural cravings of a refined intellect after full satisfaction and explanation; how fearlessly the one acquiesces in Gon's will, while the other would check us in such acquiescence, by philosophical calculations, of the result of such and such conduct on the tempers and character of the agent ; how the one in short walks entirely by faith, the other requires more or less of intellectual sight. On that one distinction we might perhaps reasonably join issue, which of the two schools may be more safely followed, as a guide through the difficulties of Scripture.

(13.) It will be said, perhaps, that the Fathers themselves have given their sanction to this principle of moral accommodation, pleading as they do for some of the Old Testament characters, the comparative imperfection of the light and strength which they enjoyed. But if we mark it well, we shall find this material difference between their accommodation, (if it may be so called,) 
and that which has been considered above,- that they never apply §iv. 13 . it to actions positively commanded or approved of God. It belongs either to characters, such as Rahab and the midwives of Egypt, who were on the whole praised and accepted, in spite of some immorality in the means they employed; which immorality however was less in them than it would have been in us, on account of the greater imperfection of their knowledge:-or else it appertains to enactments or permissions, having in them more or less of a ritual and positive-one might almost say, of a sacramental-nature; "the custom of that time, when the promise was veiled, as distinguishable from the custom of this time, when the promise is revealed." So writes St. Augustin ${ }^{1}$, with a view especially to the domestic history of the Patriarchs. And perhaps we might refer to this head the whole subject of the law of mar. riage, both before and after the time of Moses, as compared with that which had existed in Paradise, and which our Saviour renewed in the Christian Church.

Of this latter class St. Irenæus is speaking, where, having quoted St. Paul's permissive sentences in 1 Cor. vii. he infers ", "If even in the New Testament we find the Apostles allowing some precepts on a principle of condescension, because of the incontinence of certain persons, lest such, becoming obdurate and altogether despairing of their salvation, fall entirely away from God; it is no woncer, should the same God in the Old Testament also have willed something of the kind, alluring His people for their good by the aforesaid observances, whereby they might at least learn to keep the Ten Commandments, and feel them such a check as should prevent their turning to idolatry, and becoming apostates from God ; nay, and whereby they might learn to love Him with their whole heart." Thus Irenæus, to explain how the Mosaical permission of divorce might harmonize with the purer Evangelical Law, coming in its season. It was matter of permission, not of commandment; as our Lord Himself hinted to the Pharisees, when they pressed Him with it. For they having asked, "Why did Moses command divorce?" He in His reply corrected 
$\S$ iv. 14. the expression; "Moses, because of the hardness of your hearts, suffered" (not enjoined) "you to put away your wives : but from the beginning it was not so."

(14.) For an illustration of the other kind of moral accommodation, we may refer to St. Augustin, de Mendacio". "Whereas it is written, that Gon dealt bountifully with the Hebrew midwives, and with Rahab, the harlot of Jericho; that was not because of the falsehoods they uttered, but because of the kindness they showed to the people of God. It was not then their deceit which received a reward, but their good and dutiful affection. . . . For as it would not appear strange nor unreasonable, should GoD in consideration of their later good works be willing to forgive certain evil works formerly committed by them; so neither is it any thing wonderful, if GoD at one time and in one transaction beholding both,- - a deed of mercy and one of deceit,- did not only reward the one as good, but also with a view to that goodness did forgive the other which was evil. . . We may understand then that to those women, to the one in Egypt, to the other in Jericho, was rendered according to their humanity and mercy a reward, of this world indeed, but such as might also in prophetic shadow represent, unknown to themselves, something eternal. But whether at any time it be right to tell a lie, even for the sake of saving a man; this being a question, the solution of which even the most learned find a weary task, was of course far beyond the compass of ordinary women, dwelling where they did, and with the tone of morals they were used to. Accordingly, this ignorance of theirs, as also their equal blindness in many other things, things which are reserved to be known by the children not of this world but of the next; this ignorance, I say, the long suffering of Gop endured. . . . As to Rahab, when she did that deed,-good and laudable, considering her state of life,-she was not yet such as that one should require of her, 'Let your conversation be, Yea, yea, Nay, nay.' But we, in our inquiries whether any kind of lie can ever suit a good man, have an eye to the case not of an Egyptian, not of one appertaining to 
Jericho or Babylon, nor of one who is still a denizen of the $\$$ iv. 15 . earthly Jerusalem, which is in bondage with her children; but of a citizen of that city which is above, our mother eternal in the heavens."

(15.) Hitherto those cases only have been considered, in which the approbation of Holy Writ is express; let us now proceed to those which may seem to be left doubtful, being simply recorded, with no clear precept or commendation. And here it will be obvious to the most cursory examiner, that amidst great individual diversity, the Fathers, as a body, in discussing such cases, almost always lean to the favourable side. They do so in a degree, which to persons with mere modern associations may often appear extravagant, sometimes even shocking. In this they might be suspected of merely indulging, perhaps unknown to themselves, the very natural wish, of being always on the side, as it were, of those whom they believed and knew for certain to be on GoD's side. One might be tempted to allow a good deal for such partiality, were it not that the Fathers have themselves explained, fully and frankly, the principles on which they so acted. Those principles are mainly two: the one, a hearty sense of the Communion of Saints, as a still subsisting bond of union between them and the Patriarchal and Mosaical ages; the other (which shall be first exemplified) a deep and reverential sense of GoD's pcisuliar Presence and Interference through the whole of this history; a trembling consciousness that they were near the invisible line which separates His agency from that of His rational creatures; which thought, wherever it becomes habitual, will necessarily make a religious man slow to censure, lest he be found blaming his Maker's work unawares. This is the account of those passages of the Fathers, in which, considering the mystical meaning as undoubted, they seem to allege it as stopping the mouths of gainsayers. To do any thing like justice to their view, we must copy the acute reasoning of St. Augustin himself'.

"I lay down this first of all, that not only the tongues of those 
§iv. 15. men, but their very lives also, were prophetical; that the whole kingdom of the Hebrews was as it were a great prophet, great because $\mathrm{He}$ is great who was the subject of the prophecy. Wherefore in regard of those among them, whose hearts were trained in the wisdom of God, we must look for prophecies of the Christ who should come, and of His Church, not only in what 2 they said, but also in what they did; in regard of other individuals, and of the whole nation collectively, the field of prophecy lies rather in what God did with them and for them. For all 'these things,' as the Apostle says, 'were our ensamples,' our types or figures.

"And whereas the Manichæans in certain actions, the depth of which they are far from comprehending, blame what they call the sensuality of the prophets; this is no more than parallel to the reproaches which are cast by certain sacrilegious heathens on our Lond Himself, for folly, or rather for madness, in seeking fruit on a tree at an unseasonable time of year, or for a sort of childish simplicity, in stooping His head and writing on the ground, and after His answer to certain questions beginning to do the same again. For why? they have no wisdom, no sense to perceive that in great souls certain excellences resemble certain blemishes in the mean and worthless; there is some slight show, but no real fairness, in the comparison. And they who find such fault with the nobler sort are like untutored boys in school, who having learned for a great discovery that singular nouns require singular verbs, criticise the most skilful of Latin authors for the phrase, 'Pars in frusta secant.' 'For,' say they; ' he should have written secat.'

"On which one might perhaps without absurdity remark, that the verbal turns and figures of learned men are not further distant in their kind from the ungrammatical and barbarous phraseology of the ignorant, than are the figurative deeds of the Prophets from the sensual enormities of bad men. By which rule, as a boy, who should plead Virgil's figure by way of excuse for bad grammar, would be presently beaten with rods; so should any person guilty of adultery with his servant plead Abraham's example, who raised up seed of Hagar, good were it for that man to meet with some severer chastisement, and not 
to be eternally punished with other adulterers. I grant that of \$iv. 16 . these comparisons one side are the merest trifles, the other side truly great; neither does our analogy tend to such a thing as making a grammatical figure as important as a mystery, a solecism equally culpable with an act of adultery; only, by proportion, in their several kinds, what skill and ignorance are in the virtues and vices (so to call them) of language, that, although in a widely different kind, are wisdom and folly in those moral virtues and vices."

(16.) St. Irenæus more briefly had taught the same doctrine long before, vindicating the harmony of the two Testaments against the Gnostics, who were in fact but an earlier development of the Manichæan school. "The great Revealer "," says he, "is the Son of the Father, as being from the beginning with the Father. By Him accordingly prophetic visions, and differences of gifts, His own ministeries and the Father's glory, have been manifested to the race of man, in a certain train and regular system, at such time as was expedient. For where things follow each other in order, there is consistency and harmony ; and where there is harmony, there each thing is suited to the time; and where there is such suitableness, there is true expediency." ('This is the same principle as was before observed on in Augustin, that GoD's eternal law measures alike all dispensations, but that part of that law is a certain equitable consideration of circumstances; and so far Irenæus too admits a kind of accommodation or moral economy.) He goes on. "For this cause the Word became Dispenser, Steward, Distributer of the Fatrer's grace, according to the needs of mankind, for whose sake He contrived so vast arrangements." He proceeds to explain, that one of these arrangements or providences was, for the prophets of old time, announcing as they did the future vision of Almighty Gon, to see Him, see both the Father and the Son, not properly, but "so far as might practise and mould men's thoughts to receive that glory, which is hereafter to be revealed to all who love God. For not by discourse alone did the Fathers prophesy, but also by vision, and conversation, and acts which they wrought,

1 Lib. iv. § 37, p. 333, lin. 32. ed. Grabe. 
§iv. 17. after the suggestion of the Sprrit. In this sense then they beheld the invisible GoD :... in this sense again they beheld the Son of God, who is Man, conversing with men ; . . . and the several progressive portions of that work by which He sums up all, they partly beheld in vision, declared partly in words, and partly signified as in type by action; with their eyes beholding what God would have seen, by their discourse proclaiming what He would have heard, by their acts fulfilling what He would have done ; in all, as prophets delivering their message."

(17.) The instance of revelation by action, which Irenæus selects, is the marriage of the prophet Hosea, one of the cases on which the adversaries had taken occasion to speak reproachfully ${ }^{1}$. "Christ showed Himself to the prophets in their typical actions, so as by them to prefigure and show forth things to come. Thus the prophet Hosea took to him 'a wife of whoredoms;' by that act prophesying that the earth should commit great whoredom, departing from the Lord; meaning the men who are on the earth; and that out of such men GoD would be well pleased to take to Himself a Church, to be sanctified by participation of His Son, as she was sanctified by communion with the prophet."

That which Scripture here affirms of the marriage of Hosea, 2 viz., both its mystical purport, and its having been contracted by Divine order, the Fathers consider to be implied generally in the histories of the marriages of Prophets and Patriarchs ; and surely they had warrant for their opinion, in St. Paul's commentary on the narrative concerning Abraham and Hagar, which is quoted by Origen (amongst others) for this argument ${ }^{2}$ : "That the Scriptural histories of brides and handmaids should be referred to the mystical meaning, is no doctrine of ours, but received of wise teachers from the beginning; one of whom thus expressed himself, awakening the hearer's mind to the mystical sense, 'Tell me, ye that desire," \&c., (quoting the whole passage:) and then he subjoins: "Whoever will take up the Epistle to the Galatians will know how the allegory is employed in what relates to the marriages [of the Patriarchs] and their unions with their handmaids; not as though it were the purport of Gon's Word,

${ }^{1}$ Iren. iv. 37, p. 336. 26.

${ }^{2}$ Contr. Cels. iv. 43. t. i. p. 537. C. 
that we should imitate those who did so, in their external and \$ iv. 18. bodily actions, but (as the disciples of Jesus use to call it) in their spiritual ones."

(18.) These remarks of some of the most considerable Fathers may serve perhaps both to explain and vindicate the judgment of the ancient Church on certain parts of the sacred history. The result of their rule is, that whenever an action startling to our moral sense is recorded of any of the holy men of old, more especially when it is accompanied with circumstances which mark it out clearly as a Mystery or Sacrament of religion, (the term Sacrament is used as commonly applied in Antiquity,) in such instances, (Scripture being silent as to the moral nature of the action), we cannot be sure that it was not either expressly commanded, like the sacrifice of Abraham, or at least prompted by inspiration of the Holy Grost. It becomes us therefore not to criticise, but to adore.

This idea in various degrees pervades the reflections of the Fathers on the case of Rebecca and Jacob, coming by subtlety, and taking away what Esau supposed to be his blessing. One writer indeed, St. Gregory Nazianzen, has spoken of it in terms of censure. He having somewhere occasion to magnify the value of a parent's blessing, observes that " ${ }^{1}$ " one of the elder saints thought it worth obtaining even by stealth, deceiving his father $b_{y}$ meat and the contrivance of a hairy garment: he pursued a noble object by ignoble means."

But besides St. Gregory, it does not appear that any of the early Christian writers hesitated to consider the transaction in the same light, wherein it is represented by St. Augustin in the following passage?: "That which Jacob did by direction of his mother, so as to appear to deceive his father, if you consider diligently and faithfully, non est mendacium sed mysterium. Which sort of thing, if we term it a lie, by the same rule all parables and figures must be also accounted lies.... But if we are not prepared to call it lying, whensoever words signifying one thing through another are employed to communicate any truth; it is clear that

1 Apol. p. 40. D. t. i; Paris, 1609.

2 Contr. Mendac. ad Consent. c. 24, t. vi. 337. D. 
§iv. 18. not only what Jacob said and did to obtain his father's blessing, but also the discourse of Joseph, whereby he seemed to beguile his brethren, and David's feigning madness, and other things of that kind, ought to be acquitted of the guilt of lying, and rather to be esteemed prophetic words and actions, to be referred [exclusively] to the truths which we were meant to understand by them." He regards the whole as a sort of scenery, (if the expression may be reverently used) not only excusable but praiseworthy in Rebecca, as being undertaken on intimation of Gop's will.

St. Ambrose says ", "Rebecca for her part did not so much prefer one son to another, as the righteous to the unrighteous. For in the mind of that pious mother the mystery overweighed the tie of affection. She was not so much preferring Jacob to his brother, as offering him to the Lord, who, she.knew, had power to preserve the gift presented unto him." (This seems to mean that in consecrating Jacob to be the first born, she knowingly separated him from herself, and so made a great sacrifice.) "Hereby," adds Ambrose, "she provided also for Esau, withdrawing him as she did from the Divine displeasure, lest he should be involved in deeper guilt, by losing the grace of the benediction once received."

These words mark strongly St. Ambrose's sense of what we should call the sacramental nature of the transaction. In substance, that view is sanctioned also by St. Chrysostom ". "Rebecca," he says, "did this not of her own mind, but in obedience to the divine oracle. What then? a man may say, did God co-operate with such a falsehood? Nay, my brother, consider not simply what was done, but look to the purpose: that he did it not for any kind of worldly advantage, but sought to attract to himself his father's blessing. If we are always to look simply to the deed done, and not in every case to regard also the end, we shall have for the next thing to call Abraham an infanticide, and Phinehas a murderer. But not so ... . for each of them was accomplishing a Divine decree.... Still more in this case your

1 De Jacob et vita beata, II. 6.; t. i. 546.

${ }^{2}$ In Gen. Hom. 43 ; t. i. 415 . 7. ed. Savil. 
thoughts are not to dwell on the words of Jacob being formally $\$$ iv. 18 . a falsehood, but you are to understand that God, willing to bring His prediction to accomplishment, caused the whole so to take place by way of economy." So far St. Chrysostom, who proceeds to point out God's hand in many minute details of the transaction, such as Isaac's doubts being overruled; the special circumstance of his kissing Jacob, and limiting the blessing to him whom he kissed, as by a kind of sacramental sign; and Esau's not returning from the field until the economy was complete.

St. Chrysostom, we see, dwells chiefiy on the marks of providential interference in the literal transaction : others have brought out in a strong light the allegorical force of the things then said and done, from hints given incidentally in other parts of the Bible. Thus St. Ambrose ${ }^{1}$, not indulging his own fancy, but following the tradition of an elder age of the Cliurch : as appears plainly by St. Jerome's report of the commentary of Hippolytus ${ }^{2}$ on this chapter of Genesis: "Jacob went to the flock, and brought for his father the offspring of innocency, or the gifts of sacred prophecy, because to the patriarch no food he knew

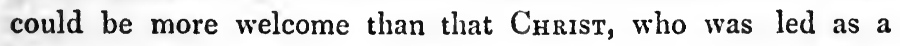
sheep to the slaughter, and as a lamb to the sacrifice.... The robe which he wore Rebecca brought out, in her character as prefiguring the Church, and assigned to her younger son the robe of the Old Testament, the prophetical and sacerdotal robe, that royal robe of David, the robe of the kings, Solomon, Hezekiah, Josiah; she brought out and gave it to the Christian people, which would know how to use the favour received. For the Jewish people had it without use, and knew not of their own rich apparel. This robe was lying in the dimness, cast away and neglected. For it was obscured by the dark gloom of irreligion, and in the narrow heart of the Jewish people it could not be spread out wider. CHRIsr's nation put it on, and it shone forth ; illumined by the brightness of their faith and the light of their pious acts. Isaac recognised the order of his race, he knew the robe of the elder Scripture, but the voice of the elder people he

${ }^{1}$ De Jacob, \&c., II. 9 ; t. i. $546 . \quad 2$ Ap. Galland. Bibl. Patr. t. ii. 485. B. 
\$iv. 19. did not recognise; and thereby he gathered that there was a change [of people.] For to this day the same robe remains, but a devouter nation hath arisen, and a confession clear and melodious ; well therefore said he, 'The voice is Jacob's voice, but the hands are the hands of Esau.'"

Augustine ${ }^{1}$ adds the selection of the two kids; "He bears the sins of others, and he bears them patiently, though they belong to others : for thus it is to wear the skins of the kids; the kids being the scriptural symbol of the two sinful people ;" (and therefore one of the appointed sin offerings;) " and Jacob wearing them to represent both CHrist and His Church in that particular, the bearing of other men's burthens."

He dwells also ${ }^{2}$ much on Jacob's being declared just before to

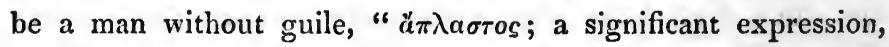
leading one to infer that the subtlety so soon afterwards imputed to him was not subtlety in a bad sense : it was a figure of speech, as when CHRist is called a Rock : it was no real fraud, especially as Jacob might truly say to his father, that for the purpose in question he was his elder son Esau; for Esau had before that made the agreement, sold his birthright, and put Jacob in his own place.

Again $^{3}$, there is the conduct of Isaac ; instead of being angry,

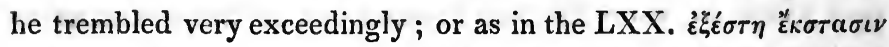
$\mu \varepsilon \gamma \alpha \lambda \grave{\eta} \nu \sigma \phi o ́ \delta \rho \alpha$ : which kind of extasy, commonly happening in the revelation of great things, we are to understand that GoD gave him warning in his spirit to confirm the blessing to his younger son, who otherwise should have incurred anger by deceiving his father.

Again ${ }^{4}$, he kissed Jacob before he blessed him, and not Esau: confirming peace to the one and not to the other.

(10.) These are the kind of circumstances, which, to the Fathers' view, betokened the special agency of the Most Hian in proceedings otherwise questionable, and which, as they thought, ought to turn censure into reverence. It will be seen that they are reducible to three heads: first, approbation of analogous
${ }^{1}$ Serm. iv. $\$ 16$; t. v. 13. D.
${ }^{2}$ Ibid. $\$ 15-2,23$.
${ }^{3}$ Ibid. $\S 21$.
4 Ibid. \$24. 
conduct in Scripture itself, such as Origen produces in the case of $\$$ iv. 19, 20.

Hagar ; secondly, tokens of special providence in the particular transaction, such as occurred to Chrysostom in the history of Jacob; thirdly, the use of known symbolical imagery, as marking intended adaptation to the Christian mysteries; which head, as we have seen, may be largely illustrated from Augustin and Ambrose on the same case.

It may be added, that they regarded themselves as especially bound to notice every thing of this kind,-to be more than commonly afraid to censure,-in treating of the lives of Abraham, Isaac, and Jacob. On passing from their history to that of others, Augustin, it will be found, changes his tone, so far as to be less positive in his vindications where the Scripture is silent. The reason is implied in the sentence which forms the transition ". "Thus much concerning the three fathers, Abraham, Isaac, and Jacob, whose Gop He willed Himself to be called, Who is our God, Whom the Catholic Church worships." 'The Church had learned from the beginning to regard them as the chosen representatives of the Head Christ Jesus, and of the Body, the Church. God was not ashamed to be called their God; they were in a peculiar sense the types of His chosen, His saints; it was wise therefore, and safe, and dutiful, to hold them in especial reverence. With this view ${ }^{2}$ Irenæus, $e, g$., has expounded the whole history of Jacob; of that one among the three, whose right to such honour the disputers of this world would be most apt to question.

(20.) In other cases, as might be expected, their scrupulousness and reverence were mainly in proportion to their sense of the mystical meaning. Thus where it is written of Noah, $\varepsilon^{\prime} \pi \iota \nu$

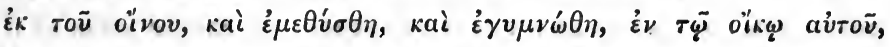
they had no thoughts other than those of deepest reverence, considering not only what is so obvious, that the whole was involuntary through ignorance on the Patriarch's part, on which many of them argue largely ${ }^{3}$; but also that which St. Cyprian writes, not in the tone of an ingenious inventor, but of one who had

1 Contr. Faust. xxii. c. 59.

2 Lib. iv. c. 38.

s E. G. S. Chrys. in Gen. Hom. 20, t. i. 226. ed. Savil. 
§ iv. 21. received it from tradition ecclesiastical ". "We find, in Genesis, in the case of Noah, an image of our Lord's Passion: that he drank of the wine, that he was drunken; that he was naked in his own house; that he lay with his limbs bare and extended; that the nakedness was pointed out by his second son, and reported abroad, but covered by the other two, the elder and the younger : and other particulars not to our present purpose."

With the case of Lot and his daughters, as might be expected, they deal in a much more doubtful tone; assigning as one reason the comparative imperfection of his character, and intimating a doubt (at least such is Origen's view ${ }^{2}$ ) whether this can fairly be reckoned among those narratives which prefigure CHRIsT's sacred economy. At the same time they are exact in pointing out the probability (to which the air of the narrative certainly would lead us) that the women acted under the supposition of the whole world besides themselves and their father having been destroyed by the fire and brimstone. "They suspected," says Origen ${ }^{3}$ " "that some such thing had happened as they had heard of in the days of Noah, and they alone with their father were left for the renovation of the human race."

(21.) This interpretation (in which many of the old writers 4 agree), while it shows that they, contrary to some people's statements, used their common sense in applying to the sacred history the ordinary distinctions and measures of right and wrong, exhibits also a clear instance of that other characteristic, which, as was before said, causes them in all their discussions to take the favourable side, to a degree which to many moderns has appeared extravagant: -their deep sense of the Communion of Saints, as a relation really subsisting between them and the Patriarchs and Prophets, and not merely as a figure of speech. It should seem as if this feeling were the natural growth of the other, viz., of the reverential consciousness of Gon's own immediate presence, overruling the Patriarchs' conduct in such a way, as to make the

1 Ep. 63. ed. Fell. p. 149.

2 Contr. Cels. iv. 45 ; in Gen. Hom. V. 5.

3 In Gen. Hom. V. $\$ 4,5$.

$\triangle$ S. Aug. contr. Faust. xxii. 43 ; S. Iren. iv. 51 ; S. Ambr. de Abral. i. 56. 
whole a series of links, binding the old dispensations to the new. \$iv. 22. Those who really contemplated the matter so, must have looked on Noah, Abraham, Jacob, and the rest, as sharers with them in the same Sacraments; not only as spiritual Fathers by the example of their faith, but also (since CHrist's coming) as brethren in His grace. The duty therefore of lenity of supposition, the command to impute no evil, would bold in their case with peculiar force; becoming as it did the more affecting, by the sense that it was demanded not for the living but for the dead; and the more serious and awful, by the knowledge, that for ought they could tell, God's own hand and counsel might be more or less in the things which they were blaming.

(22.) For these reasons we find the Fathers constantly, even where the Mystical meaning was entirely concealed from them, or where they gave it no direct consideration-we find them checking to the utmost all inclination to censure the holy men of old without express authority. The principle is laid down by Irenæus, in words the more worthy of every believer's attention, in that he utters them not as his own, but as the words of a certain Presbyter, who had heard them from the eye-witnesses and scholars of the Apostles. Irenæus, having stated it as one of the marks of a sound teacher, that " he expounds the Scriptures to us without peril, neither blaspheming God, nor dishonouring Patriarchs, nor despising Prophets," goes on to record the following, as an apostolical tradition": "That for the old Fathers, concerning those things which they wrought without the counsel of the Spirit, that censure is sufficient which the Scripture itself contains. GoD is no respecter of persons :- to things not done according to His will, He limself annexed that censure which was convenient." He instances at large in the cases of David and Solomon, concerning whom, he adds ${ }^{2}$, "the aforesaid Presbyter affirmed that the rebuke of Holy Writ was sufficient ; that no flesh might glory in the presence of the Lond."

The next sentence, whatever some may think of the statement contained in it, is at least a mark of the ancient Church's anxiety to assert for the Patriarchs, as was just now observed, a part in the

${ }^{1}$ Lib. iv. 45. p. 345. ed. Grab.

voL. VI. -89 .
2 Ibid. p. 346. 
\$iv. 22. Communion of Saints. "For this cause, that ancient Presbyter went on to say, the Lord descended to the regions under the earth, declaring to them also the good tidings of His advent ; remission of sins being appointed for them only who believe. Now those believed in Him, whosoever were before hoping in Him, i. e. those who foretold His coming, and did the work of His mysterious providences, righteous men, and Prophets, and Patriarchs. Their sins $\mathrm{He}$ forgave as he did ours : which sins, therefore, it becomes us not any more to lay to their charge; except we think scorn of the grace of God. . . . . For all men need the glory of GoD, and are justified not of themselves but by the coming of the Lord : those I mean who look steadily on His light.

" He taught moreover that their acts were written for our reproof, that we might know this first, that there is one God, both ours and theirs, whom sins cannot please, though wrought by renowned persons. Next, that we might keep ourselves from evil things. For if those elders who went before us in God's special graces, for whom the Son of Gop had not yet suffered, were visited with such disgrace, if they transgressed in some one thing, and became slaves to fleshly concupiscence ; what shall this generation suffer, as many as have despised the coming of the Lord, and turned utter slaves to their own pleasures! .... 'We ought not then', said that Presbyter, ' to be proud, nor to reproach the ancients, but ourselves to fear, lest haply after the knowledge of Christ, if we do any thing which pleases not God, we no longer have remission of our sins, but find ourselves shut out of His kingdom." "'

A little farther on ${ }^{1}$ he produces the authority of the same Presbyter for this sentiment: "As on account of those sins which the Scriptures themselves lay to the charge of the Patriarclis and Prophets, we are not to reproach them, nor become like Ham, who derided his father's shame and fell under the curse; but rather to thank God for them, that their sins were forgiven them in the coming of our Lond : even as they, he said, give thanks, and are glorified in our salvation :-So concerning those deeds which the Scriptures reprove not at all, but simply relate them, we ought not, he said,

1 Lib. iv. cap. 50. 
to become accusers; (for we are not more exact than God, §iv. 22. neither can we be above our Master) but we ought to look out for the spiritual meaning. For whatsoever things are set down in the Scriptures without censure, not one of them is idly set down, nor without meaning."

And then ${ }^{1}$ he gives the example of Lot and his daughters, adopting (it is not Irenæus, observe, but the apostolical Presbyter) that interpretation which Origen, as we have seen, doubted of as too favourable. A thing much to be remarked by those, who think little of the Mystical method, as supposing it a figment of Platonism, or a contrivance of a later school in the Church.

A signal example of the mildness above inculcated had been given by the same Irenæus a little before ${ }^{2}$, in arguing against Tatian, who denied the possibility of Adam's salvation. He contrasts Adam's proceedings even after his fall with those of the Evil Spirit, and says, "It was another who seduced him under pretence of immortality : and being seduced, he presently fears, and hides himself; not as though he could escape Gon, but in his confusion, because having transgressed His command, he is unworthy to come to the sight or speech of God. Now the fear of the LoRD is the beginning of understanding : the understanding of $\sin$ causes penitence : and to the peniterit God vouchsafes His mercy. Moreover, by his girdle or apron he manifested his penitence in the way of significant action: ... as though he had said, 'By disobedience I have lost that robe of holiness which I had from the Holy SpIrit : I now acknowledge that I deserve that sort of vesture, which can give no pleasure, but galls and vexes the body.' And this dress evidently he would always have worn, humbling himself, had not God who is merciful clothed them with coats of skins instead of the fig-leaves."

Another case very inuch in point is their view of the conduct of Abraham in Egypt, making known Sarah as his sister, not as his wife: it was no falsehood, as he himself explained afterwards, and, that there was in it no unfaithful timidity, Augustin ${ }^{3}$ argues on this ground: that "it is a sound precept, when a man has

$$
\begin{aligned}
& { }^{1} \text { Cap. } 51 . \quad{ }^{2} \text { Lib. iii. } 37 . \\
& { }^{3} \text { Contr. Faust. lib. xxii. } 36 .
\end{aligned}
$$


\$iv. 23. any resource, not to tempt the Lord his God: and that our SAviour Himself set an example to that purpose, both by flying into Egypt in his childhood, and by going up to a certain feast not openly but as it were in secret.... So Abraham among strangers, because of the exceeding beauty of Sarah finding himself in a double danger, both of her honour and her husband's life, and not being able to protect both, but having it in his power to do something for one of the two, i.e. his own life; that he might not tempt his God, he took what precaution he could; and where he could do nothing, that cause he committed to his God."

One may observe in passing, that the suspicion of any particular want of faith in Abraham on that occasion is greatly lessened by what he afterwards told Abimelech ${ }^{1}$ : that the concealment of his marriage was not a measure to which they were driven by the present alarm, but one which they had constantly used by way of precaution since they first set out on their pilgrimage.

(23.) Elsewhere the rule of favourable construction is applied, where the act is allowed to be censurable, with a view to mitigation, not entire acquittal. Thus Aaron is conjectured by Augustin ${ }^{2}$ to have proposed to the Israelites the breaking off their ear-rings, with a view to withdraw them by the hardness of the command from their idolatrous intention. Thus Theodoret ${ }^{3}$, relating the oversight of Moses in striking the rock, insists carefully on the many circumstances which might seem according to human measures to render an expression of impatience for the moment completely venial. "They (Moses and Aaron) being out of heart at their sister's death, the people set on them, mutinying for want of water; they, therefore, impatient at such extreme unruliness, used words of equivocal meaning on bringing out the water, 'Must we fetch you water out of this rock?' in a tone as if he doubted, so great was his wrath with them. It was, however, a doubt not of the soul but of the lips only: for so the

1 Gen. xx. 13.

${ }^{2}$ Quæst. in Exod. 141. t. 3. pars i. 347 : comp. Theodoret on Exod. qu. 66. t. i. 170 .

3 In Num. qu. 37. t. i. 245. 
Greek Bible expresses it, $\delta \iota \varepsilon \sigma \tau \varepsilon \lambda \varepsilon v$, he made a distinction, or §iv. 24. hesitated, with his lips." "However," adds Theodoret, "we must not forget that GoD pronounced this sentence (of exclusion from the promised land) with a view to another dispensation which He was carrying on." Here we see plainly the studious apologist : yet who can deny that the tone is right and scriptural ?

(24.) The same lenity of supposition is sometimes extended to the conduct of persons, concerning whose general character Scripture is either silent, or at first sight might appear condemnatory. Thus of Rachel stealing her father's images, Theodoret writes ", "Some say, Rachel stole them out of an affection she still entertained for them; I, quite on the contrary, suppose that, desiring to free her father from superstition, she did, as it were, make prize of them: for of her general piety we are certified by the divine Scripture." Having confirmed this by several texts, he proceeds to suggest a prophetic meaning. Jacob was a type of the LorD of all: for, as God had two peoples, - the elder, having a veil upon its heart, the younger, endowed with the beauty of faith; even so Jacob, two wives, Leah, tender eyed, Rachel, beautiful and well-favoured; the elder with many children, the younger barren: for the Church also of the Gentiles of old was barren, but became afterwards very fruitful. .... Since then, the Church, upon faith in God our Saviour, pulled up by the roots thr error of lier forefathers, Rachel, being a type of that Church, stole the idols of her father, that herein also she might offer a dim shadow of the truth." Here one is tempted to remark, how much we may lose by the cold and dry way, in which we are apt to read the sacred history, as mere matter of criticism, historical, or moral, contrasted with the high and thrilling views, wherewith the ecclesiastical rules of interpretation reward those who fairly adopt them.

Other instances of the like lenity, applied even to persons more clearly in the wrong, may be found in Theodoret ${ }^{2}$ on the bistories of Thamar, the daughter-in-law of Judah, and of the Bethel ${ }^{3}$

${ }^{1}$ In Gen. qu. 90. t. i. p. 98.

2 Ibid. qu. 95. p. 103.

${ }^{3}$ In 3 Reg. qu. 43. t. i. $487-490$. 
$\S$ iv. 25, 26. Prophet, whose advice caused the death of the messenger sent to Jeroboam.

(25.) A fortiori, one should expect the like mildness in the comments of Antiquity on the New Testament. One instance may be here given, because it relates to a matter which is and has been much misinterpreted: St. Paul's condescension in the matter of certain Jewish observances. "God forbid," exclaims St. Augustin ${ }^{1}$, "that we should account him to have done this deceitfully. For on this subject his sentence is well known; that neither such Jews as then believed in Curist should be forbidden the traditions of their fathers, nor the Gentiles, on becoming Christians, be forced to observe the same: lest on the one hand those holy mysteries, which were known to rest on the Divine command, should come to be shunned as profanations, - on the other, to be accounted necessary to salvation for all who turned to God under the New Testament. . . . . St. Paul's saying, therefore, 'I am made all things to all men,' tells us what he did in the way of sympathy, not in the way of deceitful accommodation. ..... $\mathrm{He}$ is made as a Jew to the Jews, not by deceiving them, but by putting himself, in thought, in their place and mind."

(26.) Thus far by way of illustration of the two chief principles, by which antiquity seems to have been guided, in commenting on the startling and painful portions of the history of GoD's ancient people. One more general observation remains : it is a negative statement, and requires a much larger induction than at present it professes to rest upon; but it is submitted to the judgment of those who are really versed in ancient theology, Whether the Fathers do in any case plead the Mystical meaning of a transaction as any excuse for it, granting it indeed immoral. The Mystery comes in, to show that GoD's hand was in what took place, and often, among other circumstances, may lead to the supposition of an express command from GoD, and so may indirectly tend to do away with the immorality: but the whole tone of their commentaries indicates, and sometimes they ex-

1 Contra Mendac. ad Consent. $\S 26$. t. vi. 339 : compare his correspondence with St. Jerome. t. ii. 64, 131, 148, \&c. 
pressly disavow, any thought of palliating guilt by the simple \$iv. 27. fact of the action being afterwards found typical. Thus St. Augustin ${ }^{1}$, examining in order the cavils of the Manichæans, against one narrative after another, premises in every case his literal defence or explanation, before he touches the sacramental or mysterious meaning. Thus Theodoret ${ }^{2}$, although as firmly as any one adhering to the mystical mode of exposition, advances in mitigation those circumstances only, which may be gathered from the letter, in such histories as those of Noah, Lot, and Thamar. 'Thus even St. Ambrose, who seems to have been most passionately carried away by his admiration of the elder saints, and most afraid to exercise any judgment of his own upon their conduct-and who in his second Apology for David, to which may be added some expressions about the incest of Judah, comes, perhaps, as near as any writer to a questionable plea from the mystical interpretation, as though it in some degree palliated the sin,even he, we shall find, does not enter on the consideration of the Mystery at all, before he has used considerations drawn from the literal history to adjust the degree of censure required by the case ${ }^{\mathbf{8}}$.

(27.) If we pass from these indications of caution, to express disavowals by the Fathers of immoral use of the mystical principle, we meet with one in St. Ambrose himself ${ }^{4}$, remarking on the conduct of Aaron, in assisting the Israelites to make an idol. "That renowned High Priest we can neither acquit, nor yet dare we altogether condemn him. However, he was not without a special meaning in taking away the rings and jewels of the Jews; for they who were plotting sacrilege could not have the seal of faith."

Thus St. Ambrose : and his scholar St. Augustin repeats the same caution many times. For example", "The conduct of Lot and his daughters we do not justify, on the ground of its having had a meaning, whereby it foretold the perverseness of some in future times. Their purpose in so acting was one, GoD's purpose in permitting such actions, with a view to certain

1 Contr. Faust. 1. xxii.

3 T. i. 823,8 c.
${ }^{2}$ In Gen. qu. 56, 70, 95.

4 Ep. 68.

5 Contr. Faust. xxii. 41. t. vi. 273. 
§iv. 28. typical instruction, another : His just judgment abiding the while on the sin of the persons then living, and His providence watchfully securing the mystical representation of others to come long after. The deed then related in Holy Scripture is a prophecy ; considered in their conduct who performed it, it is a crime."

Again, in speaking of the incest of the patriarch Judah : the truth of the spiritual meaning, he says, and the criminality of the act, may well stand together". "The conduct of Judah, in regard of his unbridled passion, was evil, but without his knowledge it presignified an exceeding good: and let this caution stand for all other evil deeds of men, whereby He who records their history hath seen fit to prophesy good to us."

(28.) It is not of course pretended that the Fathers acted in all cases up to their own rule : so many of them, writing so miscellaneously, all of like passions with us. But it is believed that the rules above illustrated will go a good way towards explaining the difference between their theology and ours, in what may be called the casuistry of the historical Scriptures. And we, perhaps, should read Bible history to more advantage, if we tried to keep the same principles in view; the principle, namely, of reverencing throughout the mysterious connexion of that history, even the most startling portions of it, with the Economy of our Salvation by the Son of God : and the principle of entire respect for the Saints of the Old Covenant; fearing to censure them where Scripture is silent; welcoming all reasonable topics of mitigation even where they are clearly blameable; never rudely sitting in judgment on them, but looking up to them as to elder brethren, who might of course err, but whom it is no part of ours to reprove, feeling as we must in every part of their history, read by the light of Christian faith, that we are even now with them in the more immediate presence of our common LoRd and FATHER.

It may be, that thus our notions may remain unsettled, on many actions recorded in the Bible; of which we would gladly know what to think, both for our own and other men's satisfaction. What then? it is one of the tokens of true theology, to acknow- 
ledge doubtfulness and perplexity, more or less, in every subject. $\$$ iv. 28. A religious man would not think himself at liberty to question God's moral government, because of the embarrassment continually occasioned by the inconsistencies of the good, and the general difficulty of discerning men's real character; how then dare any one positively insist on full satisfaction in his view of the conduct of God's Saints? As it is, the doubtfulness of many things has this advantage, sufficient to outweigh much annoyance; that it lessens the apparent difference between the scenes of Scripture and common life; lessens the temptation to forget how near GoD is to us ; helps us to feel our true condition, as full of supernatural wonders, could we but realize them, as ever was that of the Jews and patriarchs of old.

Moreover, the habit of thus considering Scripture will prove in some respects an important doctrinal safeguard. The Saints (be it spoken with all reverence) were types of the Almighty ; their conduct in many respects analogous to His economies; and if we use ourselves to speak or think of them hastily and irreverently, the transition will be found less violent than some might imagine, to irreverent ways of speaking and thinking of Him. Those who can bring themselves to talk superciliously, and judge by mere modern measures, of the conduct of Abraham or Jacob, or of the destruction of the Canaanites, are perhaps in a feir way to question the reality of the Atonement, or the eternity of the wrath to come.

Lastly, the same considerations may prove available, in some material parts of discipline, devotional and moral; - teaching us to acquiesce with things which we cannot account for, in the conduct of those who are more experienced in God's service than ourselves, and especially assisting us to recognize the overruling Arm, even in the worst excesses and perversions of men, and to take all tranquilly, knowing from Whom it comes.

The subject which will naturally come next in order, is the Fathers' application of the Mystical Principle to the exposition of the New Testament. 
$\S \mathrm{v} .-$ Ancient Mysticism as applied to the Interpretation of the New Testament.

§v. 1. The object of this section is, allowing the fact, that the ancient interpreters did apply the mystical principle very largely to the New Testament, to point out some of the rules by which they conducted that process, the limits within which they confined it, and the good purposes, which, under such rules and limits, it was calculated to answer.

But the very mention of mystical interpretation, as applied to the Christian Scriptures, suggests in limine a plausible objection, which it may be as well to anticipate in some measure, before proceeding any further. It may and will be said, "Whatever one may think of the degree and manner in which they allegorized the Old Testament, all must allow that to a certain extent they were borne out by Scripture in so doing. But to allegorize the New Testament at all, what is it but turning the substance into a shadow, and by consequence unsettling the very foundations of religion ?" Those accordingly, who wish to be very severe upon the Fathers, have thought proper, in treating of this head, to make mention of the wild and cloudy dreams of the early Quakers', and other modern enthusiasts; as if the two things admitted some kind of comparison.

Again, taking another point of view, it may be argued that such a line of interpretation coincides too nearly with that which St. Paul so earnestly deprecates in the Epistle to the Galatians. This, it may be said, is the very essence of the Law, that it had but a shadow of good things to come. By allegorizing the Gospel, you are so far making it also a shadow; and what is this but going back to the Law, and incurring at once all the anathemas which the zealous Apostle pronounces on all such disturbers of Christian perfection?

This way of objecting would be as just as it sounds plausible, if either the truth of the New Testament history, or what we may call the completeness of the dispensation, were impugned by

I E. g. Whitby, p. 8 ; 345 ; \& Pref. p. Ix. 
the mystical interpretations current in antiquity. But such is by no means the case. As to the truth of the history ; something was said in a former section, to shew that even Origen and his followers, who are most censurable on that head, never thought of denying or doubting the main facts ; and that even where they speak most freely of minor details, as though the apparent discrepancies of the evangelical narrative could only be reconciled by supposing an admixture of allegory, it is not so much real contradiction, which they impute to the sacred historians, as an appearance of contradiction, which they assume to be intended and providential.

Again, as to the other point, of completeness; the danger of sweeping negatives is proverbial, yet I suppose one might safely challenge the production from any orthodox writer, or from any of the school of Origen who had not been condemned as a heretic, of a single passage, tending to make out the Gospel scheme imperfect, in the sense here alleged,-Judaically imperfect-a shadow and forerunner of better things to come even on this earth; or as any other than the last and best of God's appointed ways of preparing His banished for restoration. Those blasphemies were reserved for such as Manes and Mahomet, and for that kind of infidelity, so current in our days, which allowing that the Gospel was well enough in its time, expects more however, in this and in coming generations, from the spirit of the age, than from the Spirit of the Church. We do not find even Origen's licentious disciples, who incurred Church censures in the fifth general council, stigmatized with any opinion of the kind.

History then does not warrant our attributing either of the supposed ill tendencies to the mystical way of expounding the New Testament ; and a little consideration will show that in reason and argument they are quite separable from it: as will be presently evident, on proceeding to inquire calmly, what this Mysticism, which has such an ill name, really amounts to; and on what great principles it is grounded.

(2.) The nature and amount of it may be best understood, by producing a few examples; which will serve also incidentally to shew, how early it prevailed in the Church of God, and by what 
\$ v. 2. high authorities it was undoubtingly sanctioned. Hear, for instance, St. Clement of Alexandria, descanting on the circumstances of the parable of the Good Samaritan. "Which of the three," says our Lord, "was neighbour to the sufferer?" The other answering, "He that showed mercy on him;" "Who then," says Clement ${ }^{1}$, " is our neighbour, rather than the SAviour Himself? To whom, rather than to Him, are we indebted for pity, all but slaughtered as we were by the rulers of the darkness of this world, with so many wounds, with fears, desires, angers, griefs, deceits, pleasures? Of all these wounds the only healer is $J_{\text {Esus, }}$ cutting out entirely every passion by the roots, not as the Law did, the porduce merely, the fruits of the pernicious plants, but laying His own axe to the roots of iniquity. This is He who pours the wine, the blood of the vine of David, into our wounded souls; who from the tender mercies of the $F_{\text {ATHER brings oil, and that }}$ in abundance: this is He who makes known to us the indissoluble bands of health and salvation; charity, faith, hope ; this is He who hath enjoined angels and authorities and powers to minister to us for a great reward: $i$. $e$. for the deliverance which themselves also shall receive from the vanity of the world at the revelation of the glory of the Sons of God."

Besides the main lesson or moral of the parable, he assumes it to be full of designed allusions (and surely as he exhibits them they are very beautiful allusions) to the mystery of the Gospel, the process of our salvation by CHRIST. Neither would it be safe to attribute this to the play of Clement's own imagination, or to the manner of the Alexandrian school. For we find the same turn given to the parable by Irenæus, a far graver and less diffuse writer, and trained in a remote part of the Church, where there is no cause to believe that the writings of Philo or other Jewish mystics had any particular influence. Irenæus, the disciple of Polycarp, argues thus on a circumstance of this parable". "The dew of God [the HoLy Ghost] is necessary to us, that we be not scorched nor made unfruitful, and that where we have an accuser, there also we may have an advocate [Para-

${ }^{1}$ De Div. Servand. § 29. p. 952. ed. Potter. ${ }^{2}$ Lib. iii. 19. p. 244. ed. Grab. 
cletum]: For the Lord commends to the Holy Grost that man \& v. 3. of His who had fallen among thieves, whom Himself pitied, and bound up his wounds; him CHRIST commends to the care of the Holy SpIrit, giving two pence, of royal coinage: in order, that we, who receive by the SPIRIt the image and inscription of the Father and the Son, may improve the penny committed to us, accounting for it with manifold increase to our LoRd."

It will be perceived that Irenæus is even more express than Clement, in sanctioning the allegorical exposition of this parable. Clement's language might be accounted for, by supposing him merely to be indulging in a vein of half poetical allusion; but Irenæus produces his exposition as a theological argument against an error of the Gnostics; a part of whose creed was, that the Eon Christ descended on the Man Jesus at His Baptism. In opposition to which, St. Irenæus, maintaining, of course, that it was the Holy SpIrit which so descended, proceeds to show by many scriptural arguments, how conformable that circumstance was to the office assigned to the Comforter in the economy of salvation: $e$. $g$. to His regenerating influence in Baptism; to the miracle of Pentecost, as fulfilling the promise of our LoRD; to the images of water, and dew, under which He is repeatedly described; and for his last instance he adduces, as we have seen, the circumstance of the good Samaritan on his departure committing the rescued traveller to another's care, until Himself should return; this Irenæus brings forward as a known and acknowledged type of the office of the HoLx Ghost, so well known and acknowledged, as to warrant him in reasoning from it to the interpretation of disputed passages.

So early, and in such high quarters, do we find warrant for considering our LorD's parables, with a view not only to the immediate moral of each, but also to certain hints of things future or supernatural, which even their minute details are supposed to convey; which is one considerable branch of New Testament Mysticism.

(3.) Another, and a yet more extensive one, relates not to His words, but to His conduct. It consists in tracing through details, apparently indifferent, of what befel our Divine Master on earth, 
§.v. 4. providential illustrations of $\mathrm{His}$ dealings with $\mathrm{His}$ people, or of their future fortunes, trials, and behaviour. To take an instance which occurs not seldom, and is met with very early : the minute enumeration, varying in the different Evangelists, of the circumstances attending His last entry into Jerusalem. Justin Martyr, in his dialogue with Tryphon, writes thus of a part of the dying prophecy of Jacob'. "The expression, 'binding his foal to the vine, and his ass's colt to the choice vine,' was a foreshowing of the works wrought in His first coming, and of the Gentiles also, who were to believe in Him. For these were as a foal that had never borne a burden, nor taken any yoke upon his neck, until such time as this our CHrist came, and sent His disciples, and made them followers of His own. Then they submitted to the yoke of His word, and bowed their backs to endure all things, for the blessing's sake which they waited for, and which he had foretold. And in fact, there was a certain she-ass with her colt, bound at the entrance of a certain village, by name Bethphage, which our Lord Jesus Christ, on the point of entering Jerusalem, commanded His disciples to bring to Him, and sitting thereon, He made His entry into the city. Which being notoriously done by $\mathrm{Him}$, according to what had been prophesied of the future doings of CHrist, made it evident that $\mathrm{He}$ was the Christ. . . But as to the circumstance, that the Prophetic Spirit agrees with the Patriarch Jacob, in mentioning the ass before accustomed to the yoke, as well as her colt, ... as also that He Himself enjoined His disciples, as I said before, to bring both animals; these things were a prophetic intimation to those also of your synagogue, who should concur with certain of the Gentiles in believing on Him. For as the colt unharnessed was a sign to those of the Gentiles, so also to those of your people the she-ass under her burthen. For the law given you by the Prophets is as a burthen laid on you."

(4.) The same interpretation is mentioned by Origen ; accompanying it however, as his manner is, with a conjecture of his own, which on the whole be seems to prefer. "I know," he writes",

I P. 272. C. ed. 1736.2 In Joan. tom. x. 18. t. iv. 190. D. 
"that some have interpreted the ass tied, to be the believers of the

Circumcision, released from many bonds by those who truly and spiritually had become disciples of the Word. The colt, on the other hand, they expound to be the Gentile believers, who were at large before they received the doctrine of $\mathrm{J}_{\mathrm{Esus}}$, and who in respect of their unbridled and self-pleasing ways, might be regarded as having shaken off every yoke. These expounders have omitted the circumstance of the multitude going before and following. However, one might perhaps, with some plausibility, make the former answer to Moses and the prophets, the latter to the Holy Apostles, entering all together into some mystical Jerusalem;" the meaning of which he next proceeds to point out.

The whole passage may serve as an instructive specimen of the difference between Origen and the generality of the Fathers. The exposition which he produces as second best, is evidently that in which the Church commonly acquiesced; as may further appear from the sanction afterwards given to it both by Ambrose and Augustin-Ambrose thus expressing himself". "Well is it written, 'on wlich never man sate ;' since none ever before CHRIsT called the Gentile nations into the Church." Augustin again, speaking as of an allowed point ${ }^{2}$ : “By the ass's colt on which never man had sat, we understand the people of the Gentiles, who had not received the law of the Lord. By the she-ass, (since both beasts were brought to the Lond) that portion of His congregation which came from the people of Israel; not altogether untamed, but such as to have known her master's crib."

But. Origen, not contented with this prophetical interpretation of the event in question, states also as possible, and recommends as on the whole preferable, the following moral interpretation of the same: which however he advances (it is but justice to him to remark it) with expressions denoting unaffected reverence and modesty ${ }^{3}$. "JEsus," he conjectures, "is the Word of GoD, entering into the soul, here called Jerusalem, borne on the she-

${ }^{1}$ In Luc. lib. ix. 5. $\quad{ }^{2}$ ln Joan. Tract. 51. § 5.t. iii. pars i. p. 462. A.

${ }^{3}$ In Joan. x. t. iv. 189. E. 


\section{Origen joins Moral with Type in our Lord's History.}

§v. 5. ass which His disciples had loosed from her bonds : $i$. $e$. on the uncorrupt writings of the Old Testament expounded by the disciples, whose business it is to solve them, and who are two in number: $i$. $e$. the two kinds of mystical interpretation, the moral and the prophetical : the one referring all things that are written to the healing of the soul, and with that view allegorizing them; the other exhibiting the good and true things to come, through those set before us in shadow. But He rides also on the young colt, the New Testament; (for in both we may find the word of truth,) to purify us, and expel those thoughts which buy and sell within us. And into Jerusalem, the soul, He enters not alone, nor yet with some few only; for many things must take place in us to go before the Word of Gop, which protects us, and very many to follow $\mathrm{Him}$; all however hymning and praising Him, and spreading under Him their own array and vesture, that those which are His velicles may not touch the earth, while $\mathrm{He}$ deigns to abide on them, who came down from Heaven."

Such is Origen's descant on this part of our LoRv's history: into which he was probably led, as was before hinted, by his wish to preserve as much as might be of the moral mysticism of Philo and others, in addition, not in preference, to the kind of allegory more properly Christian. Whatever may be thought of the general principle, it will perhaps be allowed, that in this instance it is beautifully applied, and may remind us of one of the Advent Hymns of Bishop Taylor ${ }^{1}$.

(5.) The arguments too are not contemptible by which Origen in the first instance vindicates the looking out for some mystical meaning in this passage ${ }^{2}$. "I should like to ask those who

1 Works. xv. 77. ed. Heber.

" Ride on triumphantly : behold, we lay

Our lusts and proud wills in Thy way.

Hosanna! welcome to our hearts. LoRD, here

Thou hast a Temple too, and full as dear

As Sion, and as full of sin.

Nothing but thieves and robbers dwell therein-

Enter, and chase them forth, and cleanse the floor," \&c.

2 T. iv. 187. D. 
think that nothing beyond the literal history was in St. Matthew's \&v. 6. mind when writing his Gospel, what was the urgent necessity of sending the two disciples into the village over against Bethphage, to find and loose the ass tied and the colt with her, and bring them to JEsus. What was there especially worth recording in the fact that our Lord sat on the ass and colt, and so entered into the city ?... If the prophecy of Zechariah merely predict the outward and bodily event as narrated by the evangelists, let us see how those who stay themselves on the letter keep entire the connecting thread of the prophecy ; what they make of the passage immediately following, about cutting off the chariot from Ephraim and the horse from Jerusalem, \&c. (an argument," he adds, "wherewith the Jews press us not slightly.) . . They cannot say that the two animals were needed on account of the length of the way, that being only fifteen furlongs. . . . Nor do I suppose that it suits well with the majesty of the Sos's Divinity, to say that so great a Being avowed Himself to have need of an ass tied and a colt with her."

There are other particulars which he mentions : but these may suffice for a specimen of the kind of criticism, by which the allegorical method was supported, when it began to be called in question: which does not appear to have been until Origen's time; the attack being most likely provoked by his incautious use of it. Certainly there seems to be a good deal of weight in such points of detail as he here alleges, not so much in behalf of his particular interpretation, as in establishing the general fact, that some spiritual meaning lies hid in these things; and if in them, then by parity of reasoning in other narratives, the particulars of which are (speaking humanly) as unaccountable as in this instance.

(6.) It may be worth while to add on this head one passage from Tertulian, as a striking example of the manner, in which those primitive readers of the New 'Testament caugbt up things which we esteem casual and transient, and improved them to spiritual purposes. He is showing how full Scripture is of allusions to the doctrine of Salvation by Water, and thus he sums up the incidental voL. vi. -89 . 
$\S \mathrm{v}, 7$. evidence of the Gospel history on that subject ". "CHrist is found never without Water; since Himself also is baptized in Water. It is by Water, at a marriage feast, that He makes what may be called the first inaugural essay of His power. In His discourse $\mathrm{He}$ invites the thirsty to that Water which is His, and eternal. Teaching of charity, He selects among works of kindness for special approbation, a cup of Water offered to a brother. It is by a Well that $\mathrm{He}$ recruits $\mathrm{His}$ strength ; He walks on the Water, as though of set purpose; $\mathrm{He}$ [repeatedly] passes the Lake; He ministers Water to His disciples ; nay, His testimony concerning baptism lasts even to His passion; when $\mathrm{He}$ is surrendered to crucifixion, Water comes in-witness the hands of Pilate; when $\mathrm{He}$ is wounded, Water bursts from His side-witness the spear of the soldier."

(7.) To this head belong the many spiritual allusions, which the ancient commentators seem to themselves to find, in the Names of places and persons, throughout our Lond's history. The principle on which they proceeded is laid down in a fragment of St. Clement of Alexandria ${ }^{2}$. "When we are accurately searching the Scriptures, since it is acknowledged that they are written in parables, we ought by the names to trace out those notions of the things, which were, so to speak, in the mind of the Howy GHost, and which $\mathrm{He}$ there teacheth, having stamped His own meaning on the words."

And for this they seemed to find warrant, not only in the speculations of Pythagoras, (whom Clement quotes in illustration of his maxim,) and in the natural forebodings of mankind in general, as expressed in a well-known and very noble stanza of Eschylus ${ }^{3}$; but also still more in the history of the Old Testament, abounding as it does with names, both of persons and places,

1 De Bapt. c. 9.

2 P. 998, Ed. Potter.

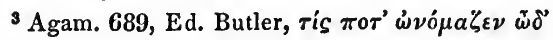

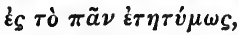

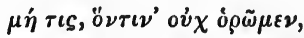

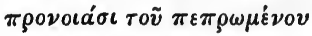

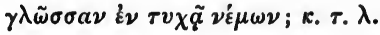


imposed (if one may so speak) sacramentally; i. e. by way of $\$ v .8$. token from the Most High of some future event, or hidden purpose. It probably seemed to Origen and those who followed him, but an extension of the same rule of interpretation, when they took pains $(e . g$.$) to ascertain the Hebrew meaning of the names of the$ Baptist and his parents. "It may be profitable," he says ", "as in many cases the true force of names is worth knowing, so in this place to consider the meaning of the names John and Zacharias : for as though it were a matter of no small consequence, at the time of naming him there was a providential interference." Then he proceeds to explain the three names: "John, $i$. e. grace from God, was born of Zacharias, i. e. the remembrance of God, according to the oath of our GoD, which is denoted by the name Elisabeth :" the three names together teaching that divine grace is the result of Gon's covenant blessing man's pious endeavours.

(8.) This example relates to persons : it may be well to give another which relates to the names of places. Origen had noticed a various reading of the name Bechabara, where John was baptizing; some copies write Bethania or Bethany, but Origen shews that this is geographically impossible, and follows up his argument, by remarking ${ }^{2}$ " "The interpretation of the name [Bethabara] suits the baptism of one who was making ready a people prepared for the LonD ; for being translated it is, "The House of Preparation:' whereas Bethany means, 'The House of Obedience.' For where else did it become him to baptize, who was sent as a messenger to prepare Christ's way before Him, than in the House of Preparation? and what more suitable birthplace than the House of Obedience, for Mary, who chose the good part which could not be taken away from her? for Martha, who was cumbered about waiting on Jesus? and for their brother, who was called Friend by the Saviour? He therefore who wishes to understand the Holy Writings without omission must not despise minute attention to names."

Here, it will be perceived, he assumes his rule so entirely, as

1 In Joan. tom. ii. 27. t. iv. p. $86 . \quad 2$ In Joan. tom. vi. 24. t. iv. 140. C. 
\$ v. 8. to think it of some consequence in settling the preference among various readings of the name of a place. And so just after ${ }^{1}$, among other reasons for reading Gergesa instead of Gerasa or Gadara, as the scene of the miracle of the evil spirits and the herd of swine: "The interpretation," he says, "of Gergesa is, ' the abode of those who did cast out ;' perhaps named, by a prophetical instinct, from the way in which the SAviour was treated by those who besought Him to depart out of their coasts."

The like interpretations abound in St. Jerome, an author little likely to be biassed in their favour by the example of Origen, but qualified for them as Origen was, by his lenowledge of the Hebrew, the want of which is probably the reason of their occurring less frequently, if ever, in Ambrose and Augustin. One might specify in particular the elegant way in which he has introduced more than one of them in the letter to Eustochium, which contains the itinerary of her mother Paula. He represents Paula addressing Bethlehem as follows " " Hail, Bethlehem, the House of Bread, wherein was born that Bread which cometh down from heaven. Hail, Ephrata, region most abundant, and fruitful, the fertility whereof is God Himself." " Not ${ }^{3}$ far from thence she went down to the tower of Ader, i. e. the flock; near which Jacob fed his" flock, and the shepherds watching by night were counted worthy to hear, 'Glory to GoD in the highest.' Presently after, quickening her pace, she began to travel along the old way which leads to Gaza, i. $e$. to the power or riches of God ; when she thought of the Ethiopian eunuch." Again, on the passage of Jeremial, "Behold 4, I will send fishers and hunters, who shall hunt you out of every hill and mountain," he writes, "These are they whom the LorD sends out to fishing, and from fishers in the sea causes them to become fishers of men. Whence also the village of Peter and Andrew comes to be called by this name: for Bethsaida in our tongue is interpreted the House of Hunters."

1 P. 141. B.

${ }^{2}$ Ep. $108 . \S 10$; t. i. 698. C.

3 Ibid. 699. D; 700. A.

Comm. in Ezech. lib. ix. c. 28; t. v. pars i. p. 339. D. 
It will have been observed, that some of these instances of $\$ \mathrm{v} .9$. allegorical names are taken not from our LoRD's own history, but from that of St. John the Baptist; and it is certain that the Fathers generally consider all that happened to him, at least before our Lond's manifestation, as capable of and requiring an allegorical exposition : e. g. " the silence of Zacharias had a symbolical meaning," says Clement ", "awaiting that off'spring, which should be the forerunner of CHRIst; that the light of the truth, the word of the prophetic riddles, might become a gospel, or voice of good tidings, and so free itself of the mystical silence."

(9.) But when we come to the times after our Lond's Ascension, it may appear that we no longer find the same frequency, the same unhesitating freedom, of mystical exposition. Neither the Acts of the Apostles, nor the historical notices in the Epistles, are treated by them with the same constant allusion to mystical meanings, supposed to be undoubtedly contained in them. Instances of the kind are certainly not wanting; as where St. Augustin on the conversion of St. Paul, reasons on the name Ananias, which he supposes to mean a sheep ${ }^{2}$; and where Origen descants in the following way on St. Paul's recommendation of a collection for the poor saints in Jerusalem". "Every one," says he, "who is spiritual, i. $e$. who serves God in the SpIRIr, and lives not according to the flesh, but according to the SpIRIt, he dwells in Jerusalem, i. $e$. in the place of Peace, and abides in the Vision of Peace: and he is one of the poor saints, $i$. e. one of those blessed poor, to whom our Lond said, 'Blessed are the poor in spirit.' . . . Being such he abides always in Jerusalem, possessing spiritual wealth. ... On the other hand, it seems to me that those whom he calls Gentiles mean the less perfect souls, as standing in need of the instruction of the more perfect : and who, if so be they are accounted worthy to become partakers with them in spiritual understanding and knowledge, ought themselves to minister unto them in carnal

1 s. Clem. Protrept. c. i. 10. ${ }^{2}$ Serm. 279. 2. t. v. 788. E.

In Epist. ad Rom. lib. x. 14 ; t. iv. p. 679. D. 
$\S$ v. 9. things : and so, when their spirit begins to be imbued with something of loftier contemplation, the flesh also, taking on itself the reins of continence and of chastity, ought to minister to the spiritual precepts."

And even Chrysostom, who in general is very jealous of producing allegorical meanings, has an intimation that he does not consider them as out of place in this part of Scripture history. For, speaking of the name Dorcas, as repeated in the verse, "They showed the garments which Dorcas had made for them," he remarks ${ }^{1}$, "Not without significance is her name added in this place, but with a view of giving us to understand that she answered to her name, watchful and alert as the animal which it signifies, the antelope. For no less than a special providence goes to the assigning of many names, as I have often remarked to you."

In spite, however, of scattered instances of this kind, it will perhaps hold, as a general observation, that mystical exposition is the exception, and not the rule, of the ancient commentators on the Acts and Epistles; whereas through all former parts of the sacred history, it undoubtedly constituted the rule and not the exception. If this be really so, it is remarkable in several ways: and one thought which it obviously suggests is, that it proves the Mysticism of the ancients, right or wrong, not to have been practised at random, not to have been merely an unthinking accommodation to the taste of the age, the school, or the individual. In such case, it will be hard to assign a reason why it should not have been applied to the fortunes of CHrist's people after His ascension, as largely as before His coning, or as to the events of His own life. Were the whole a matter of mere ingenuity, it will not surely be pretended, that the character and adventures of St. Paul, (for instance) might not be as dexternusly turned into allegory, whether of the prophetic or moral kind, as those of David or St. John the Baptist. The abstinence of the ancient writers in this respect indicates their proceeding on some definite rule or principle, whether we can succeed in ascertaining the rule or no.

1 In Act. Apost. Hom. 21, t. iv. p. 732.1 . 33. 
(10.) The several heads of New Testament Mysticism having $\S \mathbf{v} .10,11$. thus been briefly noticed and exemplified, and appearing to be first, the affixing spiritual import to the detail of parables, and to other imagery adopted by our LORD in His discourses ; secondly, the application of the like process to the circumstances of His history while on earth; thirdly, to the names of persons and places any how connected with that history ; fourthly, and much more scantily, to the records of His Church after His departure; we are in a condition to say something of the principles on which the whole depended, and the authorities by which, when cliallenged, they were accustomed to vindicate it : and in the course of the discussion it will perhaps sufficiently appear, what weight is due to the difficulty mentioned in the outset, viz. that allegorizing the New Testament at all is inconsistent with the idea of its being, eminently, if $a \lambda i_{j} \theta \varepsilon \iota a$, the final dispensation-the substance and not the shadow.

It may seem, then, that the mode of interpretation we are considering arose chiefly from the deep sense which those who used it entertained of two great truths, - fundamental truths-of the Gospel : the Divinity of our Lord, and the Communion of Saints.

(11.) First, did we really lay it to heart, as we read verse after verse of the Gospels-did we in earnest put our minds to the thought, - that this JEsus of Nazareth, the Son of Mary, is indeed the Most High God, Creator and Possessor of Heaven and Earth, and of all things visible and invisible; did we realize our conviction of this truth in connection with each and all of His actions and discourses, and of the scenes and circumstances in which we find Him engaged; we should of course feel on all these subjects, that which considerate persons feel in regard of all God's words and works; viz. that the least of them is far too deep for us; the most trivial of His commandments is exceeding broad; the slightest, to our conception, of His acts must have eternal and infinite associations and consequences. The words then and doings of our Blessed SAviour, being as they are the words and doings of GoD, it cannot be but they must mean far more than mects the ear, or the eye : they cannot but be full-charged with 
$\$$ v. 12. heavenly and mysterious meaning, whether we are as yet competent to discern some part of that meaning or no; and to look at them in that light may be called Mysticism, but is it any more than the natural and necessary result of considerate faith in $\mathrm{His}$ divine nature? Or can it be doubted, that so far as the Mysticism of the old interpreters is traceable to this conviction, so far it not only admits of justification, but the disuse of it is a fearful symptom of irreverent forgetfulness at least of that vital doctrine?

On grounds like these, we may perhaps be excused in thinking, whatever we may judge of the particular examples, that the Fathers could not be wrong in the general principle, which guided their comments in such instances as shall now be specified.

(12.) Knowing our LoRD to be the Governor and Overruler of all things, even the least, by His good providence, knowing from His own lips that not a sparrow falls to the ground without Him: they could not be wrong in noting those circumstances and accompaniments of His conduct, which in ordinary human language would be called accidental, as being in fact divinely ordered : worthy, from their nearness to Him, of being contemplated with peculiar awe, as forming part of the clouds and darkness that $\mathrm{He}$ gathers round about $\mathrm{Him}$ : which if we can at all penetrate by the help of other revelations, it is well ; if not, at least we may adore in silence.

For example ; according to men's usual way of talking, it would be called an accidental circumstance, that there were five loaves, not more nor less, in the store of our LORD and His disciples, wherewith to provide the miraculous feast. But the ancient interpreters treat it as designed and providential, in this surely not erring : and their conjecture is, that it represents the sacrifice of the whole world of sense, and especially of the Old Dispensation, which being outward and visible, might be called the dispensation of the senses, to the FATHER of our LoRd JEsus Christ, to be a pledge and mean of communion with Him according to the terms of the new or evangelical law. This idea they arrive at by considering the number five, the number of the senses, as the mystical exponent of the visible and sensible uni- 


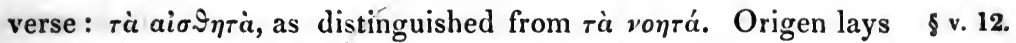
down the rule in express terms. "The number Five frequently, nay almost always, is taken for the five senses."

Accordingly St. Clement ${ }^{1}$, speaking of the Tabernacle door, which was hung on five pillars, says it was accounted by some a token of the separation between the intellectual and sensible worlds; and he adds, "Thus, by a process full fraught with mysterious meaning, Five loaves are broken and multiplied by the SAviour, to the crowd of ordinary hearers; for many one there be who regard the things of sense as if there were really nothing besides them."

Origen more plainly": "By the five loaves they perhaps might signify the outward and literal words of the Holy Scripture, literal and sensible, and therefore represented by the number of the five senses." Ambrose again", "It may seem that those five thousand, as though made up of the mere bodily senses, which are five, received from CHRist nourishment as yet little more than bodily." And Augustin ${ }^{4}$ : "To pass over this subject rapidly; the five loaves are understood to be the five books of Moses, with reason not represented as of wheat, but of barley, because they belong to the Old Testament. And barley, as ycu know, is so formed, that you come with difficulty to the nourishing part of it, wrapped up as it is in a covering of chaff, and that chaff stiff and cleaving, so as not to be stripped off without some trouble. Such is the letter of the Old Testament, clothed with the wrappings of carnal sacraments, or tokens; but if you once come to its marrow, it nourishes and satisfies. If we ask, who was the lad that bare the loaves, perhaps it was the people of Israel; with no more than childish thought bearing them only, not tasting them." And elsewhere, expessing hirnself in such a way as to connect his view obviously with that of St. Clement ${ }^{5}$. "The five barley loaves, wherewith the Lord fed the multitudes in the mountain, signify the old Law ; either because it is given to persons not yet spiritual, but

1 Strom. v. $\$ 33$.

${ }^{2}$ In Matth. tom. xi. 2 ; t. iii. 477 . B.

3 In Luc. lib. vi. 80.

In Joan. tr. 24-5.

s De Div. Quæst. 61 ; tom. vi. 24 . F. 
\$v. 13. still carnal, i. e. devoted to the five bodily senses; or because the Law was given by Moses, and the books written by Moses are five."

It should still be recollected, that neither in this nor in other like instances is the tone of the Fathers at all dogmatical. They are positive only in one point, that there is a spiritual meaning, could we but find it ${ }^{1}$; but of their own special exposition they commorily speak as doubtfully as Origen on this very place, whose language is ", "Thus far have I been able to reach in conjecturing the sense of the five loaves and the two fishes. But in all likelihood those who are better able to store themselves with [the spiritual food meant by] those symbols will be able to give a fuller account of these things."

It may be added, perhaps, in support of the exposition which he thus modestly suggests, that it suits well with the nature of the miracle, considered as an intimation of the future Eucharistical sacrifice : in which light the subsequent discourse of our LORD undoubtedly teaches us to consider it. For the offering of bread and wine, to be received back again as the LorD's Body and Blood, is in effect, as far as in each of us lies, the sacrifice of all the things of sense, of our whole earthly being, to be made heavenly by participation of Jesus Christ.

(13.) It is clear, again, referring to some examples given above, that the names of the several places which our Lord chose wherein to utter His discourses and work His miracles, will come under the head which we are now considering-that of circumstances which in ordinary history might be called insignificant, but in this can hardly be less than providential. Our Lord's moving from place to place, among the towns, mountains, and rivers of Israel, was the moving of the GoD and King of Israel, among the places which He Himself had marked out, from all ages, to be the scene of His mighty words and works, when $\mathrm{He}$ should literally visit His people.

So also, applying the same remark to His discourses, the

1 Nihil vacuum, neque sine signo apud Deum. Iren. iv. 21; ed. Bened. It seems to have been a sort of Christian Proverb.

2 Orig. ubi supra. 
imagery which He used, His references to natural objects, are to be looked at with other and far higher feelings than those of mere wonder and delight, such as the same words would cause, could we imagine them proceeding from human lips. His mention (e. g.) of the birds of the air, the lilies, the vine and its branches, the wheat and tares, and whatever else occurs of the like kind, are so many instances of the Creator applying to moral or spiritual uses His own outward and visible works; which works $\mathrm{He}$ had created, knowing in His Omniscience that He should so apply them, and therefore (among their other final causes) with the very purpose of doing so. And it is but carrying the same observation one step further, to say, that His not unfrequent allusions to domestic processes also, and the simpler modes of trade, and husbandry work, are in like manner allusions to things which Himself had prepared by His providence, no doubt with a view to such application.

The great use to be made of this will be seen by and by : at present it may serve to mitigate the disapproving wonder, with which some readers are apt to receive what may appear to them the frigid and overstrained comments of the Fathers on the figurative language of our Lord, and the details of $\mathrm{His}$ parables.

(14.) For example, St. Clement ${ }^{1}$ applies the Parable of Leaven to illustrate the reserve which all know to have been one great feature of the teaching of the early Church. "By it," he says, "the Lord indicates the method of concealment." Then, quoting the parable, he subjoins, "Either it is the preservation of the soul which our Lond here describes, - of the soul, made up as it is of three parts, [memory, understanding, and will] and preserved in the way of obedience by the spiritual power hidden in it, according to the faith; or else, [He speaks thus] because the Power of the Word, given unto us, compressed in a scanty space, but of great might, attracts to Itself secretly and invisibly the whole of him who receives It and lays It up within himself, and gathers the whole complex being of that man by 
\$v. 15. degrees into perfect unity." St. Augustin ${ }^{1}$, and St. Ambrose ${ }^{2}$, in effect give the same exposition; all agreeing to annex a certain mystical force to the three measures; to the woman; whom they take to be the Church, or Wisdom; to the hiding of the leaven: and so in other parables; those things which modern critics regard as the mere scenery or dress of the narrative, they fear to dispose of so easily, considering that $\mathrm{HE}_{\mathrm{E}}$ is speaking of them, who caused them to be what they are, with all their relations, similitudes, and association.

(15.) But if the Fathers considered as providential and mystical the mere ornaments of our LonD's discourses, and the accompaniments of His proceedings on earth, much more would they regard in the same view the substance of His conduct, His own voluntary doings. It would never come into their mind to think they knew the whole meaning and bearings of it, any more than to imagine, as they looked upwards at night, that they saw through the whole depth of the sky, because, gazing more intently than others, more and more stars had become visible to them. They seem to have contemplated the whole subject with that feeling of infinity, which dictated St. John's concluding verse, "If the things which Jesus did should be written every one, I suppose that not even the world itself should be able to contain the books which should be written." Akin to which is the saying of Origen", "That the Gospel of St. John can hardly be understood but by one who should be like the writer of it, lying on the bosom of our Lond, and declared to be the Son of Mary, i.e. as it were another Jesus by communion with the true Jesus."

According to the depth of significance here attributed to the least of our Lond's doings, we are to look at the minute details of $\mathrm{His}$ demeanour towards different persons, His modes of dealing with them for their good, as so many exemplifications, so many visible types, - of His invisible dealings and dispensations towards the same class of persons always. If even "wise men and scribes," parents, say, or teachers or masters, very often use significant actions, expressing things far beyond any dream,

1 Quæst. Evang. i. 12; Serm. cxi. t. v. 392.

2 In Luc. vii. 187, \&c.

3 In Joan. i. 6. 
that those who witness them can possibly have of their meaning; shall it seem strange to be told, that we must regard all the actions of Him, who is infinite wisdom and goodness, as so many deep economies, answering, in all probability, purposes, of which we can no more judge, than a child in arms can judge of the meaning of the holy services, which he may chance at any time to see performed in a Church.

(16.) But to produce first a few instances, in which it seemed to the Fathers that we might in some measure interpret our LonD's significant actions:-Origen ${ }^{2}$ has gone through great part of the discourse with the woman of Samaria, as a specimen of the way in which it pleases Him to deal with those who are not unbelievers but heretics: Irenæus expounds the washing the Disciples' feet to be a token of $\mathrm{CH}_{\mathrm{r} I S T}$ communicating an interest in His Passion to all the Saints which had gone before, the whole Jewish and patriarchal Church. Thus he speaks" "In the last times, when came the fulness of the time of liberty, the Word Himself by Himself cleansed away the filth of the daughter of Sion, washing with His own hands the feet of His Disciples. For this [in which we now are] is the end, [or last stage] of the human race entering on its inheritance, even GoD: that as in the beginning we were all brought into slavery by the debt of death [which we incurred], so in the end, by Him who is the Last, all who from the beginning had been Disciples, being cleansed and washed from the things of death, might enter into the life of God. For He who washed the feet of his Disciples, sanctified the whole body, and brought it into a state of pureness. Which is the reason also why He ministered food to them as they reclined, signifying those who were reclining in the earth, to whom $\mathrm{He}$ came to minister life."

Origen, and after him Ambrose ${ }^{3}$, assign a parabolical drift to the directions given by our Lord about preparing the Passover. " No one, keeping the Passover according to the will of Jesus, is below the upper room; but whosoever feasts with Him, is on high, in a large upper room, in an upper room swept, in an upper
In Joan. xiii. t. iv. $212,8 \mathrm{cc}$.
2 iv. 39.
3 In S. Luc. x. 47.
${ }^{4}$ In Jerem. Hom, xviii. 13. t. iii. 256. C. 
\$ v. 17. room garnished and prepared: and if thou go up with Him to celebrate the Passover, He gives to thee no less a gift than the Bread of blessing, His own Body, and vouchsafes to thee His own Blood. Wherefore I beseech you, go up on high, lift up your eyes on high. And to me too, when I am engaged in teaching the Divine word, the Scripture says, 'Go up to the high mountain, thou who tellest good tidings to Zion.' " And St. Ambrose ${ }^{1}$ takes occasion from the command about the pitcher of water, to descant in honour of holy Baptism, carried away, as the Fathers use to be on that subject, perhaps above all others.

(17.) It may be worth considering, whether the view in illustration of which these last examples have been offered, does not tend in some sort to explain and justify the practice which $\mathrm{I}$ have frequently mentioned, as not unusual with Origen and Clement, and with others who followed them, of adding to the prophetical or evangelical exposition of historical passages, what may be called a moral exposition also : of which an example has already been adduced from Origen, speaking of our LorD's entry into Jerusalem; and the following may serve in further illustration of it ". "The Lord in the Gospel affirms, concerning that woman who poured on His head the box of precious ointment, 'She hath wrought a good work on Me ;' intimating that he who pours ointment on the Word of God, $i$. e. who joins actual obedience with that Word, that man worketh a good work. For the Word adorned with obedience and right actions is rendered, as it were, fragrant, filled with all sweetness of precious ointments." Here would seem at first sight a confusion between the two senses of " THE WORD," standing sometimes for the Scriptures, sometimes for the Person of our Lord. But the difficulty will perhaps vanish, on considering that the Word written or spoken was regarded by Origen as one only among many forms, in which the personal WoRD vouchsafes to communicate Himself to His servants. The things then which befel our Lord "visibly and personally" might well be taken as symbolical of the mode, in which His inward and invisible presence acts on, and is received by, the hearts of His servants; as Origen himself gives us tc

1 In Luc. lib. ix. 48.

2 In Rom. ii. 5. t. iv. 480. B. 
understand, explaining the declaration of St. John the Baptist ${ }^{1}$, $\$ v .18$. "There standeth one among you whom ye know not," of " the presence of our Lord's most high Nature in all reasonable souls, reaching through the whole world." Comments, accordingly, in the Alexandrian and other Fathers, which at first sight might appear like mere metaphysical disquisitions, about the supremacy and operations of reason, may be understood of CHRIST, and the operations of His grace; only recollecting that the ancients in their piety iscribed all sound reason to the Word, or Wisdom, of the Father, enlightening the soul.

(18.) The Divinity then of our Lord, and His relation to mankind, would cause us to feel sure that all His words and doings must be so far mystical, as that they mean more, infinitely more, than meets the eye and ear of the mere human observer. But His Incarnation and Economy, of which His words and actions are part, may have had other objects, relative to other races and other states of being. Who knows but any given work or discourse of His may have reference to some of these, and we may have, consequently, to wait for its full explanation until (if ever) our eyes be opened to behold them in another world? Certainly there are obscure hints in Scripture, there is a partial, a very partial, disclosure, of some change in heaven as well as on earth, to be wrought by the Incarnation of the Sox of God. "The principalities and powers in heavenly places," it is intimated, have some deep though undefined interest in that unspeakable Work of GoD, which is our sanctification and salvation. Such hints unquestionably the New Testament contains : and it was the part of watchful piety, such as that of the Fathers, to notice and store them up: and what more natural, than that they should sometimes remember them, when engaged in the obscurer portions of the Gospel history, and should say within themselves, What if such and such a saying of our LorD, such and such a circumstance of His behaviour, evidently too profound for us, should belong to Him as the Lond of Angels rather than of men,-- should allude to His government of heaven rather than of earth?

By this train of thought, they would evidently open to themI In Joan. t. ii. 29. tom. iv. 89. D. 
\& v. 19. selves a new source of (what is called) Mysticism : the principle of which can hardly be denied, however unsoundly or presumptuously the details may have been managed. One or two examples shall be produced from Origen, the writer on whose mind these thoughts appear to have made most impression.

$\mathrm{He}^{1}$ applies the prophetic saying of our Lond, "Other sheep I have, which are not of this fold," in part to the ministering angels, who "look forward," he says, "with the rest of the Creation, to the revelation of the Sons of GoD, for whom they are commissioned to minister (being so far," as he expounds it, " "made subject unto vanity') that they with the objects of their ministration may receive the inheritance of salvation, that of earthly and heavenly things there may be one fold and one shepherd." It may be remarked, by the way, that this comment on the place in the Romans, right or wrong, is not Origen's own. It occurs, as we have seen, in Clement's exposition of the parable of the good Samaritan. " ${ }^{2}$ Curist has commanded the authorities and powers to minister to us for a great reward, viz. that themselves may be delivered from the bondage of corruption." Again, Origen $^{3}$ considers the case of the fallen Angels to be very probably part of our Lond's meaning, in that very awful Proverb, "There are first which shall be last, and there are last which shall be first." And every where he is full of the presence of the elect Angels, and delights in contemplating our invisible communion with them; not always perhaps judiciously, yet surely on the whole more wisely and scripturally, than they who banish the doctrine out of their thoughts, as though it were either a mere figure of speech, or an economy long laid aside, and to us mere matter of history.

(19.) So much for that portion of the New Testament Mysticism, which seems to arise from the constant remembrance of the Omniscience of Jesus Christ, and His Supreme Dominion over things visible and invisible. Another large class of similar instances will be found, derived from another fundamental truth, viz. the Communion of Saints. By the Communion of Saints,

${ }^{1}$ In Ep. ad Rom. lib. vii. 4. t. iv. 597, 598.

${ }^{2}$ De Div. Servand. 29.

3 In Matt. xv. 27. t. iii. 692. 
is here meant the real, but mysterious and supernatural union of $\S$ v. 20. Jesus Cirrist with His Body the Church, and with every member of that Body: by virtue of which, the actions and sufferings of the Head may be predicated of the Body, and conversely those of the Body, of the Head: Israel may stand for CHrist, and Christ for Israel: the one, $e . g$. where Moses is said to have "esteemed the reproach of Cririst," $i$. e. of God's Church and people, which is in CHRist's account one with Him, "more than the treasures of Egypt:" the other, where Hosea, combining in one expression the past and the future, says, "When Israel was a child, then I loved him, and called My Son out of Egypt."

Again, David is a type of our LorD, and through Him of the Church which is His Body, and through that again of each individual Christian as being a member of that Body : and therefore the Psalms generally are adopted by the whole Church in her assemblies, and by separate believers in their closets, with equal propriety, as the language of their devotions : they are an inspired Liturgy, provided for all ages and all lands.

As, therefore, the Divinity of our LorD even forces a considerate person to regard His demeanour towards those who came near Him in the body, as indicative of His ways of grace and trial towards us, with whom $\mathrm{He}$ is invisibly present: so the unity between Hirn and His Church would lead us to inquire, from time to time, whether things which we find happening to Him may not be prophetic tokens of the future fortunes of the Church; as well as His conduct a lesson to her, how to bear herself in her conflicts with the world.

(20.) But here the nature of the case would enforce an important distinction between the allegory of the Old Testament and that of the New; i. e. so far as both are prophetic. In the Old Testament the leading idea is, that the Church, whether diffusive, or embodied in her anointed members, king, priest, or prophet, is every where the type of CHRIST ; in the New, that Christ conversely is the type of the Church. "They from Sheba shall come, they shall bring gold and incense:"-loubtless the immediate aspect of this prophecy is towards the wise men's offering at Bethlehern; but that offering was itself prophetical of the kings

vor. vi. -89 . 
\$v. 20. of the earth coming in, and laying their glories at the feet of the Church, as the representative of CHRist on earth. Again, "He shall bruise them with a rod of iron, and break them in pieces like a potter's vessel "-is transferred in the Acts from David to Christ, and in the Revelation from Christ to the Church. Our Lord heing in this sense also both Alpha and Omega, the end of the ancient types and the beginning of a new series. In Him all that happened before was, as it were, brought to a point; and all again that should come after, was but so many developments of what He said, did, and suffered among us.

But it can scarce be necessary to dwell much on this part of the subject, since Christians in general appear to feel that each greater event of our Lond's abode on earth, His Passion, for example, in all its circumstances, was prophetic of the treatment which the Church, His Body, might expect, and at the same time symbolical of the inward process, whereby each one of His members should be trained and purified. The very expression, " taking up the Cross," seems to imply as much as this.

But if so, surely there is something to be said for the introduction of the same idea in other passages also of our SAviour's life, and in explanation of other sayings of His. For example, there is a very ancient gloss on the saying, "Foxes have holes, and birds of the air have nests, but the Son of Man hath not where to lay His head." "In this," says Clement of Alexandria ${ }^{1}$, "I suppose there is an allusive meaning; viz. that with him only who believes, and is perfectly separated from all those who in Scripture are described as wild beasts, does a resting place use to be found for the Head of all beings, the gracious and gentle WORD ;" as if our Lond's literal want of a home, when He was here in the body, betokened the scarcity, which should ever be found on earth, of souls apt to receive and lodge Him worthily. Foxes would always find their dens, and birds of the air their nests: crafty and soaring thoughts would always find hearts enough ready to entertain them : not so the frank and open, the meek and lowly, Spirit of Christ.

1 Strom. i. 23. 
Such is St. Augustin's explanation ${ }^{1}$ (amongst others); and it appears to be so far warranted, as that it is only an additional application of the same principle, which teaches us, with St. Cyprian', to consider Christ's coat without seam as a token of the unity of His Church, which her enemies, doing their worst, should be unable to rend: or with Clement ${ }^{3}$, to look on His baptism as a token and type of ours. "The Lond," he affirms, " is consecrated by the bath alone, and sanctified by the descent of the Holy Ghost. So it is ; and the same thing happens in us also, of whom the Lord is the type: by baptism we are enlightened, by enlightening we are adopted, by adoption we are consecrated [or perfected], by consecration [or perfecting] we are immortalized." St. Paul's language to the Romans and Colossians, implying CHRIST's death and resurrection to be, sacramentally and virtually, that of each baptized person, is too well known to be more than just alluded to. And there is imagery in the Revelations, in the vision of the Two Witnesses, which may justify us in surmising that the same awful events may in some sense find their counterpart in the history of the Church on earth.

Whoever will consider and follow out these and similar hints, will see reason, perhaps, to excuse many things, which a hasty reader of the Fathers would call over-bold and fanciful : he will understand how Origen might affirm ", that there are in fact as many different manifestations of the Word, as many different CHRists, as there are believers: and again, that those who rest content with the mere outward meaning of the Gospel history, not recollecting as they go on, that in this same JEsus they live, and move, and have their spiritual being - that $\mathrm{He}$ is one with them, and they with Him-they are in the same kind of error as the Judaizers, who could not find Him in the Old Testament.

(21.) So far then as the mystical interpretation of the Gospels depends on the Communion of Saints, it would appear to be amply authorized by the Scripture itself : neither need we be long to seek for similar authority in behalf of that branch of it, which

${ }^{1}$ Quæst. in Matth. v. t. iii. pars 2, p. 201. C. ; in Ps. 90. Serm. 2. $\S 7$, t. v. 733. E.

2 De Unit. Eccl. t. i. 110. Ed. Fell.

2 Pedag. i. 26.

4 In Joan. vi. 3, t. iv. 108. C. 
§v. 22. has been already exemplified : that, namely, which results from the constant endeavour to realize, as we read, our Lord's high and transcendent Nature. As to His Parables, it is certain that in those which He has condescended to explain, in that of the Tares for example, every circumstance almost is made to tell ; so far from the attention being limited, as many modern interpreters would limit it, to the general result and moral only. Many of His actions are ascertained to be symbolical, in the way of prophecy, or moral, or both : some by their correspondence with direct Parables; as the cursing of the fig-tree, which agrees remarkably with the Parable of the barren fig-tree; the multiplying the loaves and fishes, illustrated by the subsequent discourse on the Bread from Heaven; and the miraculous dranght of fishes, explained by the Parable of the net. Other actions, or circumstances of actions, have their figurative nature indicated by the use of some symbol, which GoD's providence has made appropriate, (oikziov, as the rhetoricians call it,) to some particular subject ; as the change of water into wine, where the appropriation was made known afterwards by the institution of the Holy Eucharist. In other cases, as the choice of the ass and colt for the entry into Jerusalem, above considered, the terms of ancient Prophecy were a key to the mystery of the action. As to the miracles of our Lord's mercy, healing, cleansing, enlightening, reviving,-there were sufficient hints given by Himself, in the conversations which followed upon some of them, how $\mathrm{He}$ would have them interpreted: as when He remarked on the case of the man who had been blind from his birth, "For judgment I am come into this world, that they which see not might see, and that they which see might be made blind:" and in the Parable of the relapsed dæmoniac.

(22.) The above considerations may perhaps put us in a condition to account in some measure for the comparative absence of Mysticism in the comments of Antiquity on the Acts and Epistles. Those, with whose words and actions those later Christian Scriptures are conversant, were actually in the Kingdom of Heaven: they were arrived at that final condition,-final as regards this world,-to which all former types and shadows had pointed, and in 
which, visibly or invisibly, they were now to be realized. They were not themselves, as far as we know, types and shadows of any thing further. Their condition indeed was full of mystery, of high, spiritual, invisible relations and associations: and so is our own condition, for theirs and ours are in substance one. But scantily and seldom, if at all, is any portion of the veil withdrawn, so as to justify the same kind of comment on the hidden bearings of the Apostles' history, or of that of any subsequent generation of believers, which. God Himself had taught us to venture on, in all preceding Scriptures. With the exception of those sacramental actions, which being performed according to His command, are to be regarded as purely and indeed His actions, there are now no visible doings of CHrist on earth : none, that is, visibly distinct from the doings of men; none therefore to which we are warranted in specially affixing a mystical character, as being both the doings of Gov, and of Him who is one with the Church and with each of us. "CHrist is the end of the Law for righteousness to every man that believeth:" that verse being once for all realized, the vision and prophecy is of course sealed up ; for there can be nothing beyond the end.

(23.) On the whole, there seems no want of scriptural authority for the allegory as applied by the Fathers to the New Testament, considered both in what in includes, and in what it omits. Most mocern interpreters even, and almost all devotional writers, recognise it in principle, some perhaps more or less unconsciously : but the great difference between them and the Ancients seems to lie rather in this; that the Ancients fear not to carry it out, in every part of the Gospels, and as far as it will go in every case; whereas we, in modern times, each draw his own arbitrary line, according to our own taste, or our notions of what is useful or convincing, or out of deference to the judgments we expect from others.

And some perhaps may say, "After all, where is the great harm of this? the other may certainly be more legitimate and consistent in reasoning; but practically, is it not safer, is it not even more religious and reverent, to abide by the letter, instead of perplexing yourself with expositions of which you cannot be quite sure ?" This, perhaps, is a thought not unlikely to be enter- 
§v. 21. tained by many minds. But let us be aware which way it leads :to what, in reality, it amounts. Discarding high associations from our interpretations of Scripture, under the notion that a plain man may do well enough without them, appears rather like discarding high doctrines from our creed, as if they were only fit for professed theologians. It may be, that the one does not always lead to the other, but they may be symptomatic of the same unhealthy frame of thought: and is it not generally found, in fact, that the two more or less accompany each other, both in schools of divinity and in the fluctuation of individual minds? Whitby's intense scorn of the ancient allegories was a step to the Arianism in which he finally acquiesced: and we know too well the region of doctrine towards which the merely critical and historical discussions of the last century were continually gravitating. Surely these are things worth the consideration of those, who shrink not only from promulgating, but even from fairly examining, the old principles of Biblical exposition, for fear of giving too much play to the imagination, or some such kind of irreverence. Are they not unconsciously behaving like Ahaz, who, when God Himself offered him a sign, refused to ask, under the pretence or notion, that to do so would be tempting the Iord?

(24.) It is most true, there is a great danger in the mystical contemplation of the Scriptures, more especially of the Gospcis, by how much the WORD of Life is there brought nearer to us, to be not only heard of, but also to be seen with our eyes, to be looked upon and handled with our hands. There is a great, an unspeakable danger, if our practice be not conformable. But this danger is not peculiar to the process of spiritual interpretation; it belongs equally to all ways of communicating the secrets of the Kingdom of Heaven; to the Creeds and Prayers of the Church; to the Catechisms which all children learn. And the remedy for it is not, in this or any other instance, to hide our eyes indolently from the light, which we know shines round us, but to strengthen them gradually, that they may be able to bear it; and this can only be done by moral means; $i$. e. by repentance, devotion, and self-denial. As we train ourselves, so also, according to our means, should we endeavour to prepare others, 
for the right study of the Bible. He who looks no deeper than $\$ \mathbf{v} .25$. the letter, may simply recommend candour, and patient investigation, and freedom from sensual and other disturbing thoughts : but he who knows beforehand, that the Personal WORD is every where in the written Word, could we but discern Him, will feel it an awful thing to open his Bible; fasting, and prayer, and scrupulous self-denial, and all the ways by which the flesh is tamed to the Sprrit, will seem to him no more than natural, when he is to sanctify himself, and draw near, with Moses, to the darkness where God is. And this so much the more, the more that darkness is mingled with evangelical light; for so much the more he may hope to see of God; and we know Who it is, that has inseparably connected seeing GoD with purity of heart.

As therefore God's people are continually to be told, concerning the Blessed Sacrament of the Eucharist, that it is infinitely dangerous to come near it unworthily, but they are not therefore to leave it out of their minds, but rather to think of it night and day, that they may prepare themselves, and come as Gov would have them: so is it with this mystical presence of $J_{\text {Esus }} C_{\text {HrIsT }}$ in every part of the Scriptures. We are not to shrink from the thought of it for fear of irreverence, but bearing it continually in mind, we are to train ourselves so, that we may have grace to discern it, according to our measure, in particulars. This training is no matter of intellectual acuteness, industry, and memory : they will only mislead into some wrong kind of Mysticism, if separated from a single mind, and a heart full of reverence : but he that is willing indeed to do His will, he shall know $\pi \varepsilon \rho i \tau \tilde{\eta} s \delta i \delta a \chi \tilde{\eta} s$, "concerning the manner of teaching," as well as the substance, "whether it be of GoD." Common sense surely will add, that one necessary sign of this willing reverence of heart, will be our religiously walking by the clue, which the ancient Church has given us, wherever we can keep satisfactory hold of it; never daring to contradict the unanimous voice of the Fathers, still less to treat with scorn and mockery the serious opinion, though it be but of one among them.

(25.) On the other hand, no ignorance, not even inability to read, disqualifies men from thus receiving our LORD in His Scriptures. 
\$v. 25. It does not hinder them from seeing God's hand in His natural Providence, in 'His care of their own and others' welfare: why should it make them incapable of perceiving $\mathrm{His}$ supernatural Providence, (if one may so call it) - the presence of His CHRist, in all those works of $\mathrm{His}$, the record of which they hear from time to time in Church, or at home out of their Bibles? Such perception of our Lond's presence, through the veil of the letter, is in fact the religious improvement of the fondness for type and parable, natural to all, but often most developed in those who have least means of acquiring literal instruction. From which it would seem, that we need not fear to inure even poor unlearned persons, having the fear of GoD, and leading good lives, with the ancient mode of exposition. Humanly speaking, their habits of thought make them for the most part apter to receive it, than persons of greater learning and refinement.

But whether to wise or simple, to learned or unlearned, the great and certain advantage of this method, (over and above its positive truth) is this : that it tends so directly in every part and parcel of the Scriptures, to keep up the conviction that God in CHRIST is there, ready to reveal Himself to us with a blessing, if we seek Him religiously and worthily. This conviction, continually realized and acted on, will prove to be of unspeakable value, though we never were conscious of a single discovery, a single new interpretation, in the ordinary sense of that term. Such faithful self denying labour will be worth a double " hidden treasure " to us, bringing us secretly into closer Communion with $\mathrm{Him}$, in whom are now hidden, one day to be revealed, "all the treasures of wisdom and knowledge."

These remarks may suffice, on the manner of the Fathers as Mystical Interpreters of the Bible. We shall next have to consider them as Mystical Observers of natural and providential things, and of the visible world around us : a kindred subject, as a little inquiry will show. 
\$ vi.-Mysticism as applied to the Works of Nature, and generally to the external World.

Whatever judgment persons may be inclined to form of the \& vi. 1. early Christian interpretations in themselves, it is clear and certain matter of fact, and surely well worthy of remark, that on all the great divisions of human knowledge the Fathers had, as a school, views of their own. Whether it was history of which they were speaking, or the arts of life, or morals public or private, their measures of things, and the tone they preserved, were widely different from all that had gone before them: hardly more so, however, (it is a startling but true confession,) than they differ from the principles and manner adopted in other ages, especially perhaps in our own, by Christian writers on the same subjects.

But of all branches of human knowledge there is none in which this difference is more strongly marked, than in what relates to the study of nature, and the laws and aspects of the external world. We know how very large a part of modern literature and education, nay, and of modern theology too, is occupied by instruction and research on physical subjects, and in what a tone of self-complacency men praise their times and one another, for the great and rapidly inereasing proficiency of the two or three last generations in their knowledge and command of the powers of nature. But when we turn to the first ages of Christian literature, the very first sentiment which strikes us is, the care taken every where to exclude views merely scientific and physical,- to prevent our acquiescing in that kind of knowledge, as though in itself it were any great thing. Hear, $e . g$, the tone in which St. Augustin explains what attention is due from a Christian to that, which of all physical sciences we are taught sometimes to account the most elevating,- to astronomy.

"The knowledge," he says ', " of the rising and setting, and other motions of the stars, though it bind men by no sliperstition, 
\$ vi. 2. yet is of little or rather no avail for the explanation of Holy Scripture, but is rather an impediment, by diverting attention unprofitably: and inasmuch as it is closely connected with the most deadly error of the chanters of silly predictions, it is better and more creditable to let it pass." Some might perhaps imagine that in this passage St. Augustin was ignorantly confounding astronomical with astrological science. But the next sentences contradict the suspicion. "It is true," he adds, "that besides the observation of existing phenomena, astronomical science contains in it something of the nature of history, inasmuch as from the present positions and motions of the heavenly bodies we may, according to certain rules, retrace their movements in times past. Again, it hath certain rules for judging of things future; not in the way of mere conjecture and omen, but fixed and settled rules; not such as to authorize our concluding aught from them concerning our own conduct and fortunes, which is the madness of those who calculate nativities-but facts appertaining to the heavenly bodies themselves. For as the computers of the lunar motions, observing how old the moon is to-day, are able to assign its age at any distance of years forward and backward, so concerning any heavenly body whatever, scientific reckoners are wont to give determinate answers."

It was not then from inadequate conceptions of the true province and evidence of astronomy, that St. Augustin assigned to it so low a place in the pursuits of a Christian student; but it was clearly from a perception that such knowledge was but very remotely connected with the proper duty and happiness of mankind. And St. Augustin was no unlearned man, nor at all apt to set himself fanatically against the use of human knowledge in the interpretation of Divine Truth.

(2.) But in truth he was here only expressing the constant sentiment of the Church, such as we find it laid down in the first and second ages, almost in the form and with the authority of an apostolical canon. "I $t$ is better," says Irenæus ", " to know nothing at all, no, not so much as one single cause of any of the 
things which are made, but to believe in God, and to persevere $\S$ vi. 2 . in love, than to be puffed up with that sort of knowledge, and fall from love, which gives life to man. It is better to seek

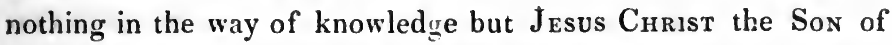
God, who was crucified for us, than to fall into impiety through subtle questions and minute verbal discussions. Suppose, $e . g$. that any one, more or less elated with efforts of this kind, should take occasion from our LoRD's saying, 'The very hairs of your head are all numbered,' to make curious inquiry, and search out both the number of hairs in each person's head, and the cause why one has so many, and another so many . . . . and so persons fancying they had discovered the right number, should endeavour to give it a meaning in reference to the teaching which they had devised for their own sect : or again, suppose that any one, upon the saying in the Gospel, 'Are not two sparrows sold for a farthing, and not one of them can fall to the earth without the will of your $\mathrm{F}_{\mathrm{ATHER}}$,' should take upon him to enumerate the sparrows which are daily taken in this place and that, and in all places, and make out the reason why so many were caught yesterday, so many the day before, and again so many to-day; and connect the said number of sparrows with his own argument: doth not such an one altogether deceive himself, and are not those who agree with him forced along with him into great impiety? Men being always forward in such speculations, that they may obtain the credit of having made out each something more than his master.

"Again, suppose a man should ask us, ' Doth not God know the whole number of all things which have been and are being made? Did not each of these numbers receive by His providence the amount which was suitable to it?' we of course should assent, and allow that nothing ever did or doth come into being without the knowledge of GoD; that by His providence is assigned to each of them its proper kind, place, number and quantity; that nothing at all ever was or is made vainly or at random, but with great finess and a lofty kind of harmony. Whereupon it would follow, that there was something admirable and truly divine in that method, which should be able both to discover and express 


\section{Final Causes not enough to secure Science from Abuse.}

\& vi. 3. the said numbers with their proper causes. Suppose him then, on receiving from us such allowance and consent, to proceed to enumeration of the sand and pebbles of the earth, yea, also of the waves of the sea, and the stars of heaven, and to invent causes for the number which he fancied himself to have found; would not his labour be justly judged vain by all considerate persons, and he himself bereft of all sense and reason? And by how much he employs himself more than others in inquiries of that kind, and the higher opinion he has of his own peculiar inventions, calling others ignorant, and ordinary, and carnal ; so much the rather is he to be judged senseless and stupid, like a planet-struck person, making himself equal with God. Yea, by the knowledge which he fancies himself to have attained, he surpasses God Himself, and aims his speculations higher than the very greatness of His Maker."

It is plain that the author of this impressive warning did not only fear the fanciful application of natural science to the things of God, but also the tendency which it has in itself to make men overweening and irreligious. It is plain also that he did not consider this evil tendency sufficiently disproved by that constant reference to the final causes of things, on which many now seem apt to rely, as taking out the sting of physical studies entirely. His painful intercourse with heresy had taught him, that the fancy of possessing rare insight into the purposes of the Author of Nature is almost as great a snare, as the habit of contemplating nature without reference to any Author. The very attempt to know all-the very dreaming of such a thing-he felt was impiety; a deep sense of our necessary ignorance, and an humble acquiescence in it, the only safeguard of the inquisitive ingenious mind.

(3.) Accordingly, those ancient writers, who have dwelt most on the wisdom of God in the creation-such as St. Basil, in his Hexaëmeron, and St. Ambrose, his imitator, one might almost say, his translator-have not thought it enough for piety, to urge every where the final causes of things, as disclosed by natural philosophy and history, but have also, again and again, admonished their readers, that no laws of nature will account for every 
thing, that the wisest must soon come to a point, where he must $\S$ vi. 3. stand still, and say, "Thus far I seem to trace things, but I can go no farther; I can but make acknowledgment with those Egyptian philosophers, "This is the finger of God.' "

Thus St. Ambrose, being about to enter on the detail of Creation in the second day's work, prefaces his remarks with a solemn caution", "not to weigh what should be said by the traditions of philosophy, and its empty deceit, nor to gather up persuasive probabilities; but to choose for their standard the rule of truth as expressed in the oracles of the Divine word, and poured into the bosom of the faithful by the contemplation of so high majesty: since it is written, 'Establish me in Thy words. The ungodly have propounded unto me discoursesbut not after Thy law. All Thy commandments are truth.'

"It is not, therefore, by the nature of the elements, but by the nature of $\mathrm{CHRIST}_{\text {H }}$ who hath done all according to His will, abounding in the fulness of His Godhead, that we are to order our thoughts of what was made, and our inquiries into that which nature could bring about. Even is in the Gospel, when $\mathrm{He}$ was curing the leprous, and pouring light anew on the eyes of the blind, the people present and beholding His works acknowledged not any course of medical cure, but, in admiration of the LonD's power, gave, as it is written, glory to Gon. Nor was it on calculation of the numbers of the Egyptians, the combinations of the heavenly bodies, the proportions of the elements, that Moses stretched forth his hand to the division of the Red Sea, but in simple obedience to the commandment of God's power. Whence also he saith himself, "Thy right hand, O LorD, hath waxed glorious in power: 'Thy right hand, O LoRD, hath dashed in pieces the enemy.'

"That way, therefore," concludes St. Ambrose, " that way do ye lift up your minds, ye who form this holy congregation; and turn your whole spirit in that direction. God seeth not as man seeth: GoD looketh on the heart, man on the outward appearance. By the same rule, neither doth man see as Gov doth. 
§vi. 3. Thou hearest, that God saw, and approved : far be it then from thee to judge by thine eyes of the things which $\mathrm{He}$ made, or by thine own thoughts to argue concerning them; rather, what God saw, and approved, see that thou account not those things matter of free discussion."

This by way of general caution. Afterwards, in a question about the conflux of the waters on the third day, he gives a specimen of the mole in which ancient piety would silence physical objections. He supposes a mere physiologist objecting to the literal truth of the Mosaical statement, that, according to the nature of water, it must have found its level before; it could not need the special divine command. St. Ambrose's answer is, virtually", "How do you know, that before God gave the command it was the nature of the waters so to glide or flow? For this is a quality which they have of their own, not after the manner of the other elements, but special and peculiar; not by any certain order of causes, but by the direct will rather, and operation of the Most High God. What He commanded, they hear. Now the Voice of God is that which gives being to nature. The actual operation of things was, and is, but the fulfilment of that Word. Presently water begins to flow, and to pour itself into one assemblage, having hitherto been diffused over the earth, and keeping its place in many different receptacles. I read nothing of its course before ; of its motion, before, I learn nothing; mine eye hath not seen, nor mine ear heard. The water was stationary in divers places; at the Voice of God it was put in motion. Doth it not appear that its nature was comınunicated to it by the aforesaid Voice of God? His creature followed His commandment, and turned His law into an usage. Thus the law of His first establishment of things bequeathed them a form to all future time. To conclude: He made day and night once for all: from that moment continues the alternation and renewal of each of them, throughout so leng a time. Even so was the water commanded to run into one assemblage, and from thenceforth it does so run." 
This principle obviously applies no less to all the great simple $\$$ vi. 4 . facts in nature: it is the principle of natural piety, "things are such, because Gop made and keeps them such :" the most skilful analyst, the most dextrous combiner of machinery, must come to this at last : and if he would but be content to refer to it, and realize his dependence on it, throughout, he would go far towards securing himself from the peculiar dangers of his line of study ${ }^{1}$.

(4.) But the one great and effectual safeguard against such idolizing of the material world, or rather of our own minds acting upon it, is the habit of considering it in that other point of view, to which Clıristian Antiquity would guide us, as earnestly as it would withdraw us from the speculations of the mere natural philosopher. I mean the way of regarding external things, either as fraught with imaginative associations, or as parabolical lessons of conduct, or as a symbolical language in whioh GoD speaks to us of a world out of sight : which three might, perhaps, be not quite inaptly entitled, the Poetical, the Moral, and the Mystical, phases or aspects of this visible world.

Of these, the Poetical comes first in order, as the natural groundwork or rudiment of the other two. This is indicated by all languages, and by the conversation of uneducated persons in all countries. There is every where a tendency to make the things we see represent the things we do not see, to invent or remark mutual associations between them, to call the one sort by the names of the other.

The second, the Moral use of the material world, is the improvement of the poetical or imaginative use of it, for the good of human life and conduct, by considerate persons, according to the best of their own judgment, antecedent to, or apart from, all revealed information on the subject.

In like manner, the Mystical, or Christian, or Theological use of it is the reducing it to a particular set of symbols and associations, which we have reason to believe has, more or less, the authority of the Great Creator Himself.

Now the first peculiarity of the Fathers' teaching on this head 
§vi. 5, 6. having been shown to be their jealousy of the merely scientific use of the external world, the next appears to be their instinctively substituting the mystical use in its room; not a merely poetical, or a merely moral, but a mystical, use of things visible; according to the exposition of the word mystical just above given.

(5.) To state the matter somewhat differently: If we suppose Poetry in general to mean the expression of an overflowing mind, relieving itself, more or less indirectly and reservedly, of the thoughts and passions which most oppress it:-on which hypothesis each person will have a Poetry of his own, a set of associations appropriate to himself for the works of nature and other visible objects, in themselves common to him with others :if this be so, what follows will not perhaps be thought altogether an unwarrantable conjecture; proposed, as it ought, and is wished to be, with all fear and religious reverence. May it not, then, be so, that our Blessed Lond, in union and communion with all His members, is represented to us as constituting, in a certain sense, one great and manifold Person, into which, by degrees, all souls of men, who do not cast themselves away, are to be absorbed? and as it is a scriptural and ecclesiastical way of speaking, to say, CHRIst suffers in our flesh, is put to shame in our sins, our members are part of Him ; so may it not be affirmed that He condescends in like manner to have a Poetry of His own, a set of holy and divine associations and meanings, wherewith it is His will to invest all material things? And the authentic records of His will, in this, as in all other trutbs supernatural, are, of course, Holy Scripture, and the consent of ecclesiastical writers.

(6.) It may be as well here to anticipate an objection, not unlikely to occur on first meeting with the above statement. How, it may be asked, are we to know, whether any particular image in an ancient Christian writer be properly mystical, or merely moral or poetical ? the momentary flight of some pious fancy, the edifying analogy observed by some impressive teacher, or a true token from the CrEator of all things, given to our senses, of some truth which He would fix in our hearts? Any given image, on the face of it, may be either of these three: how are we to distinguish, with any certainty, the one from the other? 
Now, in the first place, the objection proceeds on the unhappy and untenable supposition, that the truth, if we can at all approach it, must be clear and plain to us throughout, and leave nothing unaccounted for. Surely there may be in the remains of Antiquity a human and a Divine Mysticism, without our being always, or even generally, able to draw the exact line between the two. We ourselves may be unworthy to decypher the writing, or our age may have lost the key to it, and yet we may be sure that it is, in part at least, a communication from the Source of Truth : and the fact may be most desirable for us to know, were it only that we might learn reverence in our way of dealing with the subject.

Is there not something analogous in the case of Holy Scripture itself? We have reason to think that the personal character and circumstances of the several inspired writers was permitted to influence them, more or less, in their style and mode of composition. But where, and how far, we can have no exact knowledge. It is seldom, if ever, given us to determine, what images were suggested to any Prophet or Apostle by his own ordinary experience, and what were immediately prompted by the HoLY GHost.

If this does not hinder our using the Scriptures to edification, no more need the other prevent our profiting by the imagery of the Fathers, in our mode of considering the visible and external world.

(7.) In effect, however, universal consent will carry us further in this matter, as in many others, than we should be apt beforehand to imagine. There is a wonderful agreement among the Fathers, in the symbolical meanings, which they assign to most of the great objects in nature; such an agreement as completely negatives the supposition of the whole having sprung from mere poetical association. It were against all calculation of probabilities, that so many writers, of various times, nations, and tempers, and in such different lines of life, should either light on the same set of figures independently of one another, or coincide in imitating any one who had gone before them with no special authority; more especially, as many of the symbols are far from possessing, at first sight, that exquisite poetical fitness, which would be required, regarding the whole as a matter of taste; on the convoL. vi. -89. 
§ vi. 8. trary, not a few of them are blamed, by the disparagers of Antiquity, on this very account, that they are so forced, overstrained, and irrelevant, and what classical judges might perhaps call $\psi v \chi \rho a ́$.

Thus they complain, not perceiving that the fact on which they rest, if it were granted, tends on the whole to make us suppose a higher origin for the imagery in question, than any man's poetical or imaginative taste. Such writers, for example, as St. Ambrose or St. Cyprian, St. Chrysostom, or St. Gregory Nazianzen, who evince in their remains the most vivid sense of poetical delicacy and beauty; -when we find them all concurring in the use of symbols, such as have now been described, must we not suppose that they drew from a common source, and were guided in their selection by something deeper than imaginative delight in the beauties of nature, and in the exercise of their own ingenuity?

(8.) The same may be said of the hypothesis (if such should occur to any one) which would make these allusions of the old writers merely moral; i.e. so many analogies or similitudes selected by themselves, from the course of human life or external nature, to render some truth or precept more forcible and vivid. I do not deny that such analogies occur; especially when they are employed, as by St. Basil and St. Ambrose, in their Hexaëmeron before mentioned, in descanting on the works of Creation. For example, we may take St. Basil's account of a mode which the gardeners had of correcting the insipid wateriness of certain fruits.

" ${ }^{1}$ Some plant the wild figs close to the cultivated: others bind the fruit of the forest fig to the mild and cultivated sort, and so heal its insipidity, the juice of the wilder having the effect of keeping the other from melting and falling away. Would you know what this riddle, presented to you by nature, signifies? That we should often do well to resort even to those who are aliens from the faith, and from them assume a kind of steady vigour, for the performance of good works. I mean, shonld you see any one either living as a heathen, or separated from the

${ }^{1}$ Hexaëm. v. 7. t. i. 47. C. Ed. Bened. 1721. 
Church by perverse heresy, yet behaving soberly and observing \& vi. 8. discipline generally in his moral conduct, do thou draw more strictly the bands of thine own goodness, and so become like the fruitful fig-tree, gathering energy to itself from the presence of its wild kindred, so as both to stay its fruit from falling, and cherish it more effectually to its full size."

It is easy to see that St. Basil produces this particular parable as an invention of his own, claiming no particular authority for it. And this I call the moral way of symbolizing natural objects.

At the same time, it may appear from the phrase, $\tau i$ oo

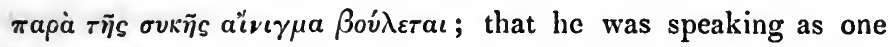
himself aware, and among persons who made no question, that every part of nature has its appropriate a'virpa, if we could but find it out. Now this was an opinion which St. Basil was little likely to frame for himself, through excessive indulgence to his own fancy, since he of all the Fathers most earnestly protests against the unrestrained use of allegory. We must then conclude that the sacramental or symbolical view of nature which he implies in the last-mentioned clause, had been received by him as an acknowledged truth, not struck out as a speculation of his own.

In other places indeed he avows it more distinctly : e.g. where he speaks of the heavenly bodies": "If the heaven is vast bevond the measure of human understanding, what mind then shall have power to trace out the nature of the invisible things? If the sun, which is subject to decay, is so fair, so large, so swiftly moving, yet so regular in fulfilling its courses,-being both for magnitude proportioned to the universe, so as not to exceed the due relation to the whole system, and for beauty a sort of clear eye to nature, the very ornament of all creation,-if I say this be a sight of which one can never have too much, what must He be for beauty, who is the Sun of Righteousness! If the blind have a loss in not beholding this our sun, how great is the sinner's loss in being deprived of the rRue Ligir." Of this epithet, True, thus applied, more will be said by and by ; I will

${ }^{1}$ Hexaëm. vi. i. t. i. 50. E.

I 2 
$\S$ vi. 9, 10. but suggest here, that on consideration it may possibly be found to involve the whole theory here contended for.

In the next paragraph, St. Basil speaks thus of the heavenly bodies in general: "As the fire is one thing and the lamp another, the one properly having power to enlighten, the other made to conduct the light according to our needs; so were the lights of heaven now framed as a vehicle for that purest and unmingled and immaterial light. Even as the Apostle calls certain, 'Lights in the world,' although the True Light of the world is other than they ;-such as that by participation of It the Saints became lights of the souls whom they disciplined, delivering them from the gloom of ignorance:-so also in the creation was this visible sun, stored with that brightest light, by the MAKER of all, and kindled in the world."

These, and similar divine parables, so to call them, are evidently introduced in somewhat of a different tone from that before quoted about the cultivation of figs, which was introduced expressly and formally as a new thing; whereas these assume a certain familiarity, on the hearer's part, with the symbolical imagery.

(9.) If one were to call these latter, of the sun and stars, examples of a symbolical or sacramental view of nature, it would perhaps be no improper mode of expressing the fact here intended; viz. that the works of GoD in creation and providence, besides their immediate uses in this life, appeared to the old writers as so many intended tokens from the Almighty, to assure us of some spiritual fact or other, which it concerns us in some way to know. So far, therefore, they fulfilled half at least of the nature of sacraments, according to the strict definition of our Catechism : they were pledges to assure us of some spiritual thing, if they were not means to convey it to us. They were, in a very sufficient sense, Verba visibilia.

(10.) This relation of things sensible to spiritual, appears to be indicated by St. Irenæus, who is the rather to be quoted on such a subject, because he seems to be unsuspected of Platonism, or any like forms of opinion, such as are supposed to have biassed the Alexandrian school. He states as follows the 
analogy between God's visible dealings with us, and His invi- $\$$ vi. 10. sible dispensations.

"The Word was made the dispenser of the Fatrier's grace for the profit of men, on account of whom He made so many arrangements; on the one hand shewing God to man, on the other presenting man to God; on the one hand maintaining the invisibility of the $\mathrm{F}_{\mathrm{ATHER}}$, lest at any time man should become a contemner of Gon, and that he might always have something to reach after and advance towards; on the other hand, manifesting God to the sight of men by many arrangements, lest man, falling altogether away from God, should cease to be. For the glory of God is a living man, but the life of man is the vision of God. And if that manifestation of GoD which is by the creature, supplies life to all things living upon the earth, much more that manifestation of the Father, which is by the Word, supplies life to those who have the sight of God ${ }^{1}$."

This sentiment seems to warrant us in extending to the whole creation the maxim which occurs repeatedly in Irenæus, as concerning the Old Testament. "Nihil enim otiosum, neque vacuum signo, apud Deum." The occasions, indeed, on which this saying is introduced, belong either to the types of the Law, or the history of the Patriarchs. But the saying itself has a proverbial air which gives it a much wider reference. It may seem to answer to that deep sentiment, which appears to run through the philosophical works of St. Augustin, and which he has himself expounded in the Book de Libero Arbitrio, II. 41.

"As the whole life of the body is the soul, so the happy life of the soul is God. . . And in so much as it is granted us to rejoice in those true and certain goods, gleaming upon us even while yet in this dark journey, consider whether this be not what is written concerning wislom; ... ' she will shew herself to them cheerfully in the way, and meet them with every kind of Providerice :' i. e. which ever way thou turnest thyself, she speaks to thee by certain traces which she hath impressed upon her works, and when thou slippest back to external things, 
§vi. 10. recalls thee by the very forms of those external things. So that whatsoever delights thee in the body, and allures thee by the bodily senses, thou mayest perceive to be according to certain numbers; and inquiring its origin, mayest return into thyself, and understand that whatever reaches thee by the bodily senses, cannot be to thee an object of approbation or the contrary, except thou hast within thee certain laws of beauty, to which thou mayest refer whatever seems outwardly fair to thee."

Then, having given instances in the works of nature and of art, in the beauty of motion and of form, and in the science itself of numbers, gradually tracing all to their mysterious origin, Gon revealing Himself by His Word or Wisdom, he breaks out into the following beautiful admonition :

"Woe to those who forsake Thee their guide, and go astray in Thy footsteps; who love Thy beckonings instead of Thee, and forget what Thou intimatest by them, $\mathbf{O}$ Wisdom, most delectable light of the purified spirit. For never dost Thou cease to beckon to us, what and how great Thou art, and all beauty in Thy creatures is but so many beckonings of Tbine."

Elsewhere, in a vein of stricter argument, he shews how each created thing, in that it is created, is an image or symbol of the Most Holy Trinity.

" All these things then, made as they are by Divine skill, exhibit in themselves both a certain unity, and a certain kind, and a certain order. For whatever of these things exists, is first some one thing, such as are the frames of bodies, and the intellec-

2 tual powers of souls : next, it is formed according to a certain kind, such as are the figures and qualities of bodies, and the

3 faculties of knowledge or of art, which distinguish souls : lastly, it craves or retains a certain order, to which head belong the weights and positions of bodies, the appetites and delights of souls. It behoves us therefore, looking at the Creator, who is understood by the things that are made, to form the idea of a Trinity, whereof in each creature, according as it is meet, is to be seen some trace ${ }^{2}$."

1 Ibid. 43.

2 De Trin, vi. 12. 
(11.) But it is not so much the manner of the Fathers to express § vi. 11. their principles of interpretation in set statements, as to be continually referring to them, exemplifying them, and variously bringing them out. Now there is no need, of course, to prove the abundance of mystical allusion in the early Christian writers. It is the very point which has most exposed them to the censure of modern schools. But it may be of use to produce some specimens of it, which, if they be fairly selected, and sufficiently explained by the general statement above, may so far afford a presumption in its favour. Perhaps it will be as fair an experiment as any, if we take the two treatises which have been already cited, the Hexaëmeron of St. Basil, and that of St. Ambrose: if indeed they can properly be denominated two treatises, the one being in many parts but a free translation of the other.

Their peculiar fitness for such a purpose, lies partly in their subject, and partly in the character of their authors. The subject, the history of creation, was one which put them especially on their guard against excess of symbolizing, to the disparagement of the historical sense ; as is proved by St. Basil's earnest and repeated protest, cited before in these papers. His habits of thought were moreover of that severe and scrupulous cast, which would least suffer the imagination to take liberties.

The tendency of St. Ambrose, it may be thought, was rather the reverse of St. Basil's in this respect. Bnt he too has several observations, implying that he dared not indulge his own or his hearers' fancy for mystical expositions, beyond a certain extent. Comparing the literal meaning to simple fare, which it is both charity and good sense to offer, rather than send the guests away hungry; " Elisha," says he ${ }^{1}$, " did not blush to set before them barley loaves: and are we ashamed, when we find things thus designated by their simple and proper names, to understand by them simply the things created ? We read of Heaven, let us take it to be Heaven : we read of earth, let us understand that earth which bears fruit." 


\section{The whole Visible World, a Type of the whole Invisible.}

§vi. 12,13. Ambrose then apologised for abiding so much by the letter: Basil strongly reproved those who were for wandering from it too widely. Concerning each therefore, it is evident, that when they did allow themselves to allegorize, they were proceeding on some principle, not merely pleasing themselves. The one probably would have had more of this sort, the other less, had it not been for the Church's recognised line of interpretation. As it is, they furnish between them a list of symbols, which ranges through no small portion of created nature.

(12.) First, we have the sum of this visible world declared to be an index or token of the invisible. " Some," observes St. Ambrose ${ }^{1}$, " understand the word, 'beginning,' in the first verse of Genesis, not in reference to time, but before time: as meaning the chief point, or head, as if one should say in Latin, summa operis; heaven and earth being the sum of all visible things. And visible things seem to bear relation, not only to the fitting up of this world, but also to the setting forth of things invisible, and to furnish a sort of argument of the things which are not seen; according to the saying in the Prophet, 'The Heavens declare the glory of GoD, and the firmament sheweth His handywork.' After whom the Apostle, in other words, but in the same sentiment, winds up his discourse, saying, 'That the invisible things of Him are understood by the things which are made.' For we readily think of Him as the Author of angels, and dominations, and powers, by the moving power of whose Word this world, so beautiful, was caused to be out of nothing, not having before existed."

(13.) As to particulars : the arch of the $s k y^{2}$ is a canopy spread over the tents and dwellings of the saints. This, in reference to its form : and then, in reference to the material of which the canopy of the tabernacle in the desert was made, the sky again is a scroll, whereon are written "the names of those many, who have attained Christ's favour by their faith and devotion; to whom it is said, 'Rejoice, because your names are written in heaven." " 
The flight and hovering of birds, again, is a token that there $\$$ vi. 13. are Powers in heaven above who watch our proceedings in this lower world. Hence a well-known saying of our Lord's is quoted by St. Ambrose ${ }^{1}$ as follows : " " The birds of heaven do always behold the face of My Fatier which is in heaven.' And the clause, 'Birds around the firmament of heaven,' intimates that the Powers which are in that visible space, behold all things in this region, and have all brought under the observation of their eyes."

The waters flowing into the sea, are the people gathered into the Church of Christ ". "The water," says St. Ambrose, "knows how to be gathered, how to shrink and flee away, when GoD gives the word.... Let us be like this water, let us recognise one congregation of the Lord, one only Church . . . . To us also it hath been said, 'Let the water be gathered from every valley,' and there hath ensued a spiritual gathering, and one people: the Church hath been replenished from among the heretics and heathens.... This is the Church which hath been 'founded upon the seas, and prepared upon the floods.' For upon you it is established and prepared, who, like rivers run down into it, clean from a pure fountain : concerning which it is said, 'The floods have lift up, $O$ LORD; the floods have lift up their voice through the sound of many waters.' And it goes on, 'Wonderful are the swellings of the sea ; wonderful is the Ioro in His high places.' Good rivers are ye : for ye have drunk of that eternal and full fountain, wherein He flows who saith to you, ' $\mathrm{He}$ that believeth on $\mathrm{Me}$, as the Scripture saith, out of his belly shall flow rivers of living water." "'

In pursuance of this thought, the sound of the sea is the Church service ${ }^{3}$. "What else is that concert of waves but a kind of concert of the people? For which cause it is a true similitude, which is commonly made of the sea to a Church, first receiving or swallowing by all its porches certain waves of people entering in long array, then in the prayer of the whole congregation sounding as with refluent waves, when in harmony to the

1 Hex. ii. 15.

2 Ibid. iii. 2-6.

3 Ibid. iii. 24. 
$\S$ vi. 14. responsories of the Psalms an echo is made, a breaking of waves, by the chanting of men and women, of virgins and children."

(14.) Herbs again, and flowers, are the life and body of man. "When thou seest "," says St. Basil, "a blade of grass or a flower, let it guide thee to the thought of human nature, remembering the image of the wise Prophet Isaiah, 'All flesh is grass, and all the glory of man as the flower of grass." But this of course is too obvious to need dwelling on.

Tares and weeds are false principles: not every kind of sin, but wrong and perverse teaching. "Such spurious seeds"," remarks the same St. Basil, " are produced not by any change in the seed-corn, but subsist by an origin of their own, having an appropriate kind. Yea, and they fulfil the image of those who adulterate the doctrines of the LorD, and in no genuine way become disciples of His word, but rather are corrupted by the teaching of the Evil One, yet mingle themselves with the healthful body of the Church."

The smell of flowers is the odour of sanctity. "How great," exclaims St. Ambrose ${ }^{3}$, " is the beauty of a well-stored field! What fragrance! what sweetness! what satisfaction to those who till it ! how impossible to express it worthily, were we to use our own language! But we have certain testimonies from Scripture, wherein we see that the fragrance of a field is compared to the blessing and grace of the Saints ; as saith holy Isaac, 'The smell of my son is like the smell of a field.' "

Thorns on roses betoken the sting of pleasant sins, as says St. Basil ": "The rose at first beginning was thornless, but afterwards to the beauty of the flower the thorn also was superinduced; that close to the delightfulness of pleasure we might have pain besetting us in every case, remembering sin, on account of which the earth was sentenced to put forth to us thorns and thistles."

Grafting, in its several forms, is moral and devotional improve-

1 Hexaëm, v. 2. t. i. 41. D.

2 Ibid. v. 5. p. 44. B.

3 Ibid. iii. 36.

Ibid. v. 6. t. i. 45 . A. 
ment. "Let no one therefore," says St. Basil ", " as yet living in \$ vi. 15. evil, cast himself away in despair, knowing that as husbandry alters the qualities of plants, so the training of the soul according to virtue is capable of mastering every sort of distemperature."

The myrica, or tamarisk, is the plant chosen by the Spirit through Jeremiah, as an emblem of a double mind: for "as such persons," says St. Ambrose 2, " are every where at call, at once professing, with the good, kindness and simplicity, and connecting themselves as closely as possible with the worst of men: so also these shrubs, by a contradictory kind of rule, grow both in watery and in desert places."

The palm is the chosen type of eternal purity. Other evergreens ${ }^{3}$ - " the olive," for instance, "and the pine-never put off their apparel ; yet, however, they often change their leaves, which keep the tree clothed in beauty, not by perpetual continuance, but by uninterrupted succession. But the palm remains ever green by the preservation and enduring, not the changeful succession, of its leaves. The very first which it put forth, it retains without substitution or fresh supply. Do thou then, $O$ man, become like unto it, that to thee also it may be said, 'This thy stature is like unto a palm-tree.' Preserve the verdure of thy childhood, and of that natural innocence, which thou didst receive in the beginning: that, planted as thou art beside the rivers of waters, thou mayest have thy fruit prepared in thy season, and thy leaf may not fall. 'This verdure of ever-flourishing grace the Church having attained in CHRist, saith, 'In His shadow I sat down with earnest desire.' This gift of verdure in the first instance the Apostles also received, that as no leaf of theirs could ever fall away, so their very shadow should be the healing of the sick."

(15.) Proceeding to the works of the fourth day, we have another set of well-known symbols. The Sun, the greater light, is our Lord; the Moon, the lesser light, the Church. " "He appointed the moon for certain seasons, and the Sun knoweth his going down.' This place," St. Ambrose tells us ", "appears to be commonly understood in a mystical sense con-

1 Hexaëm. v. 7. t. i. 46, $47 . \quad 2$ Ibid. iii. $69 . \quad 3$ Ibid. 7 l. \$ iv. 7. 
$\S$ vi. 15. cerning $\mathrm{CHRIST}_{\text {and His }}$ Church : $i$. e. of our LoRD's recognising His own death and passion in the body, when He said, ' FAther, the hour is come, do Thou glorify Thy Son :' that by such His setting $\mathrm{He}$ might give eternal life to all, who till then were oppressed with the setting of perpetual death; that His Church might have her certain seasons, of persecution, namely, and of peace. For, like the moon, she seems to fail, but fails not indeed. She may be overshadowed, fail she cannot. Thus in persecutions some indeed depart, and cause her to wane, but it is in order to her being replenished by the confessions of martyrs; and blood shed for CHRist makes her bright with its triumphs, and her full orb pours forth more abundantly the glory of her devotion and faith. For the moon is subject to a diminution of her light, not of her orb ... as may be easily seen when the air is pure and transparent." A little after he adds ", "This is the true moon, which, from the never-failing light of her brother borrows for herself the lustre of immortality and grace. For the Church shineth not with her own but with our SAviour's light, and draws to herself splendour from the Sun of Righteousness, that her word may be, ' $I t$ is no longer I that live, but CHriss liveth in me." "

The Saints are stars in this mystical heaven, as we have seen in a passage from St. Basil.

The four quarters of the heaven again have their part in this sacred and universal language. What the east stands for is well known: and St. Ambrose, from a passage in Canticles, tells us that the south is the region of the Church" " "Tell me, Thou whom my soul loveth, where Thou feedest, where Thou abidest in the south:" i.e. as he explains it, " in the region of the Church, where righteousness shines forth, where judgment is dazzling as the noon-day, where no shadow is seen, where the days are longer, because the Sun of Righteousness abides in them more continually, as in the summer months." And the east and south being interpreted, we know of course the probable interpretations of the two opposite regions; which however shall not 
be dwelt on here, as they do not occur in the treatises now under §vi. 16. consideration.

(16.) Of the many instances which might be specified from among the works of the two remaining days, it will be enough only to mention three: two of them remarkable as having been constantly employed, by poets and moralists, to represent some portion of those truths, by association with which the Church has made them Mysteries. St. Basil uses the silkworm as an evidence or token of the Resurrection ". "You, who disbelieve St. Paul, concerning the change when our bodies shall be raised, what say you on beholding so many of the inhabitants of the air, how they change their forms? As we are told concerning that horned Indian worm, that it first changes into a grub, then goes on and becomes a chrysalis, and neither in this form does it abide, but decks itself with broad and light pinions. When ye women, therefore, sit carding out the produce of their work, I mean the threads which the Seres export to us for the manufacture of soft garments, I would have you take it as a manifest hint of the Resurrection, and not disbelieve the change which Paul announces to all men."

Again, St. Ambrose sanctions the image, now almost trivial among us, of the turtle dove, as representing chaste and holy widowhood. "The Law of God," says he ${ }^{2}$, "hath selected the turtle as a gift of chaste and pure sacrifice. In fact, when our Lon, was circumcised, this was the offering: 'a pair of turtle doves, or two young pigeons.' For this is the true sacrifice of CHrist : bodily chastity, and spiritual grace. Chastity is associated with the turtle, grace with the pigeon. For it is said that when the turtle has been widowed by the loss of her proper mate, she refuses to pair any more .... See how great is the grace of widowhood, which is honoured even in birds."

One instance more may be mentioned, taken from among quadrupeds. The wolf is with St. Ambrose, as in holy Scripture, the appropriate symbol of the Evil One, wasting the Church or besetting it. Upon this he observes (assuming common notions to be true) ${ }^{3}$ : "If a wolf sees a man before he is seen, the sight

1 viii. 8. t. i. 78. E.

2 v. 62.

3 vi. 26, 27. 
\$vi. 17. takes away the man's voice; but if he feel that the man saw him first, it takes away his fierceness, and he is unable to give chace. .... Do beasts then know how to seek what shall profit them; and art thou, $\mathrm{O}$ man, ignorant of thy proper helps? Knowest thou not how to take away the courage of the Adversary, that as a wolf seen first he may not escape thee, that thine eye may discern his perfidy, and thou mayest be beforehand with him, and stay the course of his words, - blunt his audacity and sharpness of disputation. Whereas, if he anticipate thee, he takes away thy voice. ... Again, if a wolf rise up against thee, take a stone, and he flies. Thy stone [of defence] is Chrisr. Betake thee to CHrist, and the wolf flies, nor shall he be able to confound thee." Thus even popular and legendary sayings, on matters at first sight farthest from religion, were made to convey high lessons, and remind men of sacred duties.

(17.) Perhaps this exemplification of the mystical use of all God's works, in the order of their creation, may be not unfitly crowned with mention of that Image of God, which, as St. Augustin explains, both in his books on the Trinity and in the City of God, man bears in his mind, even in every thought of it. Thus he speaks, in the later and more highly finished of the two works just mentioned:-after pointing out how in all His creatures, and especially in the threefold division of knowledge, which even Gentile Philosophy acknowledged, Gop had left covert traces of the FAther who made all, the Son by whom all were made, the Hory SpIrit, or impersonated goodness, for whom all were made; - he proceeds to say ${ }^{1}$ : "And we even within ourselves acknowledge a certain image of GoD, even of that most High Trinity, at unspeakable distance indeed, yet such, that nothing among God's creatures is by nature more akin to Him; and we expect yet a new creation, to bring it very near to Him by resemblance also. For, first, we are: secondly, we are conscious of being: thirdly, we delight in this our being and consciousness ... ${ }^{2}$ These three we hold for certain of our own; we trust not for them to other people's testimony ; we ourselves feel them present, andidiscern them by an inward and most infallible kind of sight."

1 De Civ. Dei, xi. 26.

2 Ibid. $\$ 28$. 
"Because therefore we are men, made after the image of Him §vi. 18. who created us, to whom appertains True Eternity, Eternal Truth, Love both Eternal and True; and He is the very Trinity, Eternal, and True, and Beloved, neither confounded, nor separated : in those things of course which are beneath us, feeling as we do, that they neither could at all exist, nor be contained under any idea, nor either seek or maintain any order, except they were made by Him who in the highest sense Is, in the highest sense is Wise, in the highest sense is Good: let us trace out His footsteps, so to call them, impressed on all the things which $\mathrm{He}$ hath made, though on some more, on some less; but in ourselves contemplating the Image of $\mathrm{Him}$, even as that younger son in the Gospel, let us arise and return to ourselves, in order that we may return to $\mathrm{Him}$, from whom by transgression we had withdrawn ourselves. There our being shall no longer incur death; nor our knowledge, error ; nor our love, disappointment "."

(18.) Yet further: as the soul of man appears to be, in this sense, an image of the Most Holy and Undivided Trinity, so his body is divinely adapted to the expression of the several virtues and graces, which Gos would new-create in him. St. Ambrose, in the end of his treatise so often referred to, has worked out this idea in considerable detail.

"The Forehead is an image of the soul," he says ", " speaking in the countenance; it is a sort of ground or tablet of Faith, on which day by day the Name of the Lord is inscribed and retained ${ }^{3} . "$

Again, alluding to the Kiss of Peace in the Holy Communion ", "By the Lips," says he, "Piety and Charity are pledged, the faithful affection of entire love is expressed."

Again " "The Hand is that whereby we both work and dispense divine mysteries : by the name whereof the Son of God did not scorn to be designated, where David says, 'Thy right Hand, O Lord, hath wrought mightily: Thy right Hand, O Lord, hath exalted me.'" Thus he makes the Hand the symbol of active devotion.

1 De Civ. Dei, $\$ 28$.

- Hex. vi. $\mathbf{5 8 .}$

3 i. e. when pcople cross themselves.

4 Ibid. 68.

3 Ibid. 69. 
§ vi. 19, 20. Lastly, the Foot by the same statement ${ }^{1}$ expresses humility and diligent obedience.

(19.) Upon these examples, taken collectively, one or two observations may be made.

First, It will have been seen that the great majority of them, the most important, and those of which the writers speak most positively, are gathered out of Holy Scripture itself; a circumstance which singly would afford some presumption, that in the rest of their imagery, not so immediately Scriptural, they did not altogether indulge their own private fancies.

Again : if the figures used by any writer appear at first sight irreconcileable with those used by another, or by himself elsewhere : this also may be paralleled in Scripture, and in both will generally admit of explanation, by tracing the original allusion a little farther back. $E . g$. Water, as is well known, is the oikeiov, the choice image, both in Scripture and in the Fathers, to express God's Holy SpIrit communicated to His Church. But St. Ambrose, as we have seen, makes the same waters the emblem of Christ's people flowing into the Church: as St. Cyprian $^{2}$ had done before him, where he teaches that the water in the Eucharistical cup is the token of the Christian people. But these two meanings are not inconsistent, if we conceive the Blessed SpIrit to be graciously identifying Himself with the people whom $\mathrm{He}$ sanctifies ; representing the change wrought in them as so entire, that henceforth they, the whole being of each of them, may be considered as effects and gifts from Him. Or, if no such explanation occurred, still the incongruity would not be greater than that which is found in the different applications of this same symbol of water in the Holy Scripture itself: on comparing, e.g. that living Water, which represents the Unspeakable Gift, with the waters on which the mystical Babylon sate, representing " nations, and kindreds, and peoples, and tongues."

(20.) Thirdly, It may seem strange that some of these mystical allusions should be grounded on fable, not on fact: that to the 
Phœnix ', for example, and to the conception of the Vulture ${ }^{2} \S$ vi. 21. without a mate (which is alleged in association with the Immaculate Conception). And the scorn is inexpressible, with which the old ecclesiastical writers, from St. Clement of Rome downwards, have been visited, among modern critics, on this ground especially.

But in the first place, these supposed facts, many of them, are brought forward not merely as providential intimations of mysterious Truths, but as arguments also from analogy, to silence gainsayers. St. Clement, for example, says in effect, "You believe this history of the Phœnix; why should a resurrection be thought incredible by you ?" It is clear that the force of this depends not on the absolute truth of the statement, but on its general acceptance by those to whom he was addressing himself.

Further; this also is one of those topics on which objectors had need look well to themselves, lest they find that unawares they have been dealing irreverently with the undoubted Word of God. What are we to make, on their principle, of the inspired direction to go to the ant, consider her ways, and imitate her forethought, now that it appears to be held among naturalists, that the common notion of that insect's frugality is no better than a common error ${ }^{3}$ ? Whatever account can be given of that passage in Scripture, may be given, apparently, of like allega tions, now found erroneous, in the writings of the Fathers.

(21.) Lastly, no doubt a considerable number of the above cited instances of Mysticism in things visible, will appear to some very cold, strained, and unnatural. Of these, however, not a few will be found, on closer examination, to be no more than developments, applications, or extensions, of imagery authorized by Scripture itself, or by the Universal Church. And even where that cannot be made to appear, it is dangerous surely so to assume the contrary, as to indulge any light disrespectful thoughts of such similitudes or associations, or of the writers who pointed them

I S. Ambrose, Hex. v. 79. S. Clem. Rom. Ep. 1. 25.

2 S. Ambr. v. 64, 65.

3 Kirby and Spence, Introd. to Entomology, vol. ii. 46.

voL. vi. -89 . 
$\S$ vii. 1,2. out ; considering how many such things may unquestionably be found in Gon's own Word, which, if we lighted upon them in any other book, we should be tempted to treat with the same kind of disrespect. Here, as in every part of our patristical studies, it may be well to bear in mind the dream of Jacob, that we may not to our fear and shame have to awake by and by, and say, "Surely the Lond was with us in so many places, betokened by so many of His creatures, and we knew it not, but treated the thought unworthily."

$\S$ vii. Warrant of Scripture for the Mystical View of things nalural.

(1.) Enough, it is presumed, has been said on this subject, so far as mere illustration of the fact goes. The store of examples which has been adduced from two brief treatises only, the one by St. Basil, the other by St. A mbrose, on the six days' work of creation, must be enough to shew any attentive student, that if the Fathers were wrong in this matter, they were most perseveringly and obtrusively wrong. If the principle of Mystical Interpretation be at all an unhealthy symptom, it is so, not as a local evil, but as a constitutional taint.

But it will be the object of this section to give some reasons for believing, that such use of external things was intended by the Almighty from the beginning of the Creation; reasons taken from Scripture, and to be illustrated perhaps hereafter by the apparent ways of GoD's Providence, in preparing mankind for Gospel Truth.

(2.) First, then, attention is desired to the use of the word $\dot{a} \lambda \eta \theta \iota \nu$ s, True; in the New Testament. It will be found very significant, and to some may appear almost decisive, on the point now under consideration.

Careful readers, of the Epistle to the Hebrews more especially, must have noticed how the things of the Christian Dispensation, as distinct from those of the Jewish, are characterized by this epithet, $\dot{a} \lambda \eta \theta_{\iota} \nu$ á. Thus our SAvrour is designated as $\tau \tilde{\omega} \nu \dot{a} \gamma^{\prime} \omega \nu$

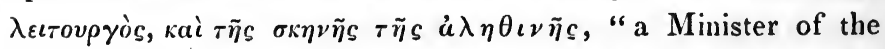
Sanctuary, and of the True Tabernacle." And afterwards the

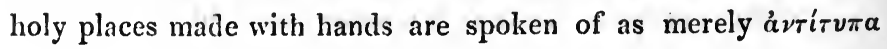


$\tau \tilde{\omega} \nu \dot{a} \lambda \eta \theta \iota \nu \tilde{\omega} \nu$, "Figures of the True ${ }^{1}$." The word has evi- $\S$ rii. 2. dently a relative signification: it implies the substance in opposition to the shadow; answering perhaps most exactly to "real" in the language of the present day. And this agrees well enough with the classical use of it : $e . g$. in Aristotle's Ethics" : "To be well and rightly framed by Nature towards the pursuit of the best end,

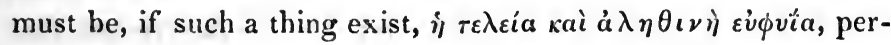
fect and real excellence of Nature :" inplying evidently that there were spurious qualities, claiming that name improperly. And again, in the same author ${ }^{3}$, "In our reasonings on practical matter, general statements are koเvórepol, 'more comprehensive,' but particular ones are $\dot{a} \lambda \eta \theta \iota \nu \dot{\omega} \tau \varepsilon \rho o \iota$, ' have more of reality in them.'" So Demosthenes speaks of $\phi i \lambda \lambda_{\iota} a \lambda \eta \eta \iota \iota v o i$, "true friends ${ }^{4}$," and

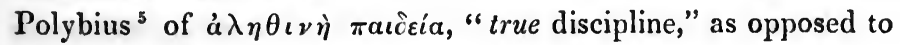
pretences of extraordinary warmth of affection, or skill in training.

Such also will be found to be the force of the word in the LXX. answering most frequently to the Hebrew substantive אֶ:ְ: much in the same usage as the subsiantive $\dot{a} \lambda \dot{\eta} \theta \varepsilon \varepsilon a$, which, by the confession of all commentators, more especially in St. John, means the antitype as opposed to the type: "The Word dwelt among us, full of Grace and Truth :" "Grace and Truth came by Jesus CHRist:" "They that worship Him, must worship Him in Spirit and in Truth:" "Ye shall know the Truth, and the Truth shall make you free :" "I am the Way, and the Truth, and the Life:" "When the Spirit of Truth is come, He shall guide you into all Truth." In all these places, and in others similar to them, the exposition of Theophylact seems to be generally received, "The word, Truth, may be understood by way of contrast to the old figures or types, which were not the Truth,

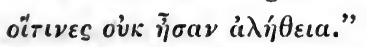

With this notion on our minds of the force of $a \lambda \lambda_{i j} \theta \varepsilon \iota a$ and its kindred words, let us proceed to examine such places as the

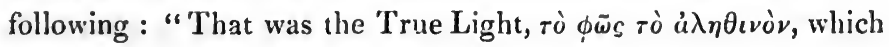
1 Heb. viii. 2 ; ix. 24.
2 iii. v. 17.
${ }^{3}$ Ibid. ii. vii. 1.
1. t. i. 113, 27. Ed. Reiske.
${ }^{5}$ I. i. 2. 
\$ vii. 2. lighteneth every man that cometh into the world:" "I am the True Vine, $\dot{\eta} \ddot{a} \mu \pi \varepsilon \lambda o s \dot{\eta} \dot{a} \lambda \eta \theta \iota v \grave{\eta}$-and My Fatuer is the Husbandman:" "Moses gave you not that Bread from Heaven, but My Father giveth you the True Bread from Heaven : tòv á

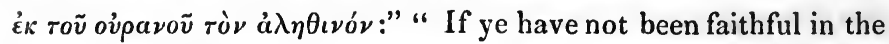
unrighteous Mammon, who will commit to your trust the True

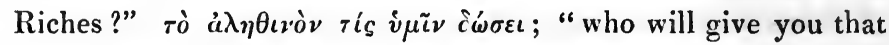
which is real and true, not merely pretence and shadow ?"

On these and the like places it seems natural to inquire, If the mention of the True Sanctuary, the True Tabernacle, the True Holy Place, leads us to think of those particulars, at least in the Jewish economy and ritual, as shadowy and typical of things far more real, far more perfect than themselves : does not the mention of the True Vine, the True Light, the True Riches, tend in the same manner to encourage a notion, that the external and visible objects, so referred to, have their counterpart in a world out of sight, wherein things exist in some manner secret to us, but as much more substantial and excellent than the mode of their being here, as the things of the Gospel and Church of Christ are better than those of the Law and Tabernacle of Moses? As it was not possible for a thoughtful believing person, having once heard of the True Tabernacle, to consider that which stood in the wilderness as any other than an unreal figure of the true; so when the Holy SpIrit had spoken to men of the True Light, faithful hearers must have learned thenceforth to have far other and higher associations with this light which we see, than they could have had otherwise. They know that it is now but a faint earthly shadow of a radiance as much more real than itself, as it is purer and more unspeakably glorious. And so of the other instances, in which the same form of speaking is implied.

But further : as the mention of the Sanctuary and Tabernacle, the Ark and certain other particulars, must of course lead reflecting minds, even without further information, to the surmise, that in regard likewise of other points not specified, and in short in its whole range and detail, the Jewish economy was typical of the Christian; so when the True Light and the True Vine are named, we are naturally carried on to say to ourselves, "What, if 
the whole scheme of sensible things be figurative? What, if all \& vii. 3. ai $\sigma \theta \eta \tau \dot{a}$ answer to vonià in the same kind of way as these which are expressly set down? What, if these are but a slight specimen of one great use which Almighty God would have us make of the external world, and of its relation to the world spiritual ?"'

Certainly the form itself of speaking, with which these symbols are introduced, would seem to imply some such general rule: "That was the True Light;" "I am the True Vine;" "who will give you the True Riches?" taking for granted in a manner the fact, that there was somewhere in the nature of things a true counterpart of these ordinary objects, - a substance, of which they were but unreal shadows; - and only informing us in each case, with authority, what that counterpart and substance was.

Should it further appear, that among those to whom the Scriptures were addressed, there existed a feeling or opinion, call it poetical or philosophical, or let it have been a mere popular fancy, that such a connexion as this language seems to point to really exists between the worlds visible and invisible; the argument for the proposed interpretation of the word $\dot{a} \lambda \eta \theta \iota v \dot{\nu}$ would seem to be so far strengthened. We may reason here as about real possession by Dæmons. The more popular the opinion, the less likely, surely, to find countenance in the language of inspiration, if it were an error.

Now it would seem, that to one large class at least, of those to whom the writings of St. John were at first addressed,-the Hellenistical Jews of Alexandria,-this doctrine of correspondence between things seen and unseen was familiar and very acceptable.

(3.) But not to pursue this topic further at present; let it be considered, whether there are not, on the face of Scripture itself, other obvious appearances in its favour. In the first place, there is the broad fact, that the revealed oracles deal so largely, I had almost said so unreservediy, in symbolical language taken from natural objects : and next, what is equally obvious, that the chosen vehicle for the most direct divine communications has always been that form of speech, which most readily adopts and invites such imagery; viz. the Poetical. These are undeniable 
§vii. 3. and surely most significant circumstances, and hardly to be accounted for by the sayings of those, who would reduce all Mysticism to the mere workings of human fancy. Let us reflect, distinctly and at large, on each of them.

And first, as to the symbolical language of Scripture, is there not something very striking, to a thoughtful reverential mind, in the simple fact of such language occurring there at all? This is not meant of merely metaphorical and figurative language, expressing one human and temporal matter by another; but the case intended is, when truths supernatural are represented in Scripture by visible and sensible imagery. Consider what this really comes to. The Author of Scripture is the Author of Nature. He made His creatures what they are, upholds them in their being, modifies it at His will, knows all their secret relations, associations, and properties. We know not how much there may be, far beyond mere metaphor and similitude, in His using the name of any one of His creatures, in a translated sense, to shadow out some thing invisible. But thus far we may seem to understand, that the object thus spoken of by $\mathrm{Him}$ is so far taken out of the number of ordinary figures of speech, and resources of language, and partakes thenceforth of the nature of a Type.

For what is it, wherein our idea of a Scriptural Type differs from that of a mere illustration or analogy? It appears to lie chiefly in these two things : first, that the event or observance itself, to which we annex the figurative meaning, was ordered, we know, from the beginning, with reference to that meaning: next, that the ideas having been once associated with each other, by authority of GoD's own Word, reverential minds shall never thereafter be able to part with that association; the sign will to them habitually prove a remembrance and token of the thing signified: and this also must have been intended in the first sanctioning of the type, being the inevitable result, in all minds that fear GoD, and watch for the signs of His presence. Thus Abraham's sacrifice of Isaac, for example, had it been related only by Josephus, might well have been used by way of similitude or comparison to illustrate the sacrifice of GoD's only begotten Son, on the same mountain, two thousand years after: but it is not clear that we could have positively called it a Type. 
That which warrants us in doing so, is the constant interpreta§ vii. 4. tion of the Church, confirming the thought which would naturally enter into good and considerate hearts on reading of it in the Scriptures.

Now let us transfer this notion of a Type, from historical events related in Scripture, to such allusions as are now in questionallusions to the works of nature, and the outward face of things. There also the same distinction is clearly conceivable. Let an uninspired poet or theologian be never so ingenious in his comparisons between earthly things and heavenly, we cannot build any thing upon them; there is no particular certainty, much less any sacredness in them: but let the same words come out of the mouth of GoD, and we know that the resemblance was intended from the beginning, and intended to be noticed and treasured up by us; it is therefore very nearly the case of a Type properly so called.

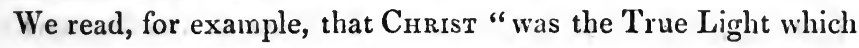
lighteneth every man that cometh into the world." This, perhaps, in some part of its sense, might be an image not unlikely to have occurred to an earthly orator, and we might have profited by it, as expressive and edifying, and there would be an end:- but now we are informed by it, that even in the first creation of the material light, God liad respect to this our spiritual Light ; the one was designedly formed to be an image of the other; and such an image as believers should recornise, having their attention drawn to the resemblance by the Word of GoD Himself. May we not then apply the same term in this case as in the former, and may we not say that the Light visible is a natural Type of God manifesting Himsref by His Son, as Isaac on the mountain was an historical Type of our Lond yielding Himself to the death of the Cross?

(4.) Now if there were in the Book of God but one such image taken from the works of nature, it might cause in thought ful minds a serious apprehension, that other cases might exist, of a like intended resemblance between the worlds visible and invisible, though none of them were as yet clearly and expressly declared to us. Our natural tendency to express things unseen by what we see, would seem to have acquired a real though 
§ vii. 5. slight sanction and warrant from above : and we might without irreverence begin to speculate (if the word may be used,) on other possible associations and mysterious meanings.

Indeed we should be almost driven to such speculations, in the case supposed, of earthly and heavenly Light. The idea of Light necessarily implies that of its opposite, Darkness; and naturally, to beings framed and conditioned as we are, it implies also the ideas, of morning and evening, sun, moon, and stars, shadow and sunshine, twilight increasing and decreasing, and many others : for all which, many would be inclined to imagine counterparts in the spiritual world, after they had been once made aware that the Light itself was intended to be typical.

Now, on further examination of the Scriptures, they would find these their anticipations verified. They would find that as Light was the regular symbol of Him, by whom the Father is manifested, who is God of God, Light of Light, the Word who hath declared the Invisible; so is the Sun in the heavens the scriptural token of the Word Incarnate, "coming forth as a bridegroom out of His chamber, and rejoicing as a Giant to run His course." They would find the condition of the world without Christ represented as "darkness covering the earth, and gross darkness the people ;" the dawnings of His manifestation, when incarnate but yet unborn, compared to the morning twilight or "dayspring from on high :" and the severe trials and apparent failures of the faith, which are to be expected even under the Gospel dispensation, these they would find compared to an evening twilight, endeavouring to prevail, but overcome by the sun which never sets: as we read, "At evening time there shall be light."

Other passages would shew them the Moon as the chosen emblem of mortal imperfect human nature, reflecting more or less of the Light which flows from CHrist, less in the Synagogue, more in the Church of the New Testament: and again the stars, as lesser lights, Patriarchs, Apostles, Bishops, such as are any how employed in turning many to righteousness. Eclipses, rainbows, and other phenomena might be added.

(5.) But if the one idea of light and darkness, with their various relations and modifications, were found thus, from beginning to 
end, allegorized, not by our imaginations, but by Scripture itself; -one might reasonably conclude the like in the case also of the other great and leading parts and attributes of the material world : one might without presumption infer details and particulars, where express Scripture gave only the general and comprehensive statement. Thus if we only found the Church called generally the Vineyard of the Lorn, His pleasant field, and the like, we might reason on the processes of cultivation, the marks of a good or unwholesome stock, the tokens of wrath and farour; though we nowhere read such parables as those of Isaiah and our LorD, developing the idea with authority.

If one of two contraries were clearly symbolical, the other would be understood to be so likewise : if good seed and noble vines are GoD's obedient and accepted ones, there would be no need to tell us that weeds and thorns and tares are the children of the Wicked One.

Where two things are by nature inevitably and inseparably related to each other, if Scripture give us the spiritual force of the one, it should seem hardly possible to avoid inferring that of the other. Thus if Gon's regenerate ones, taken separately, are as good seeds cast into the ground, the loaf which comes of that good seed, stands naturally for the same persons formed into une Church or company: an imagination proved to be a verity by the double offering sanctioned in God's law, first of ears of corn, afterwards of consecrated loaves-and this, (to anticipate another part of our subject) is an example of the manner in which Gov's ancient ritual gives apparent sanction to the symbolical use of things natural.

(6.) Now considering to what an extent nature (so to speak,) delights in pairs, and groupings, and relations ; how "one thing," as the son of Sirach observes, is every where "set against another ;" how impossible it is to find an object single and uncombired with all others, or to limit the extent of the associations and connexions, which manifest themselves one after another, when we set about tracing any one of the works of creation, through all its influences and aspects on the rest; it ought not perhaps to seem over strange, if the symbolical and 
\$ vi:. 7. mystical use of any one thing were thought to imply the possibility at least of a similar use and bearing in all things.

And this presumption will evidently be strengthened, as the instances which Holy Scripture furnishes multiply, and as we find, on more and more acquaintance with it, that its typical allusions are more developed, and come out on its surface, as stars meet the eye more abundantly, when we continue gazing for any time on what seemed at first merely a space of open sky. St. Augustin appears to have been particularly gifted with the power of discerning this kind of holy imagery. It is really wonderful, as one reads his descants, on the Psalms more especially, how many allusions he detects and brings out, with more or less ingenuity in the particular instance; so that it must require, one would think, a mind prepossessed altogether with dislike of the principle of Mysticism, not to be carried away with him. But even without stopping to discern these more latent allusions, it should seem that on the very surface of Scripture so many of the chief visible ohjects are invested with spiritual meanings, that to affirm the same of the whole world of sense ought not to sound too hard a saying. The symbols which are mentioned are almost enough to make up between them "a new heaven and a new earth," and to complete the proof, that "the first heaven and the first earth" are to be regarded both generally and in their parts, as types and shadows of those which are out of sight.

On this head there appears something instructive in the circumstance that the phrase just referred to, "a new heaven and a new earth," occurs both in the Old and in the New Testament at the very conclusion of a great body of Prophecy ${ }^{1}$, in the course of which the imagery of the visible world has been, one may say, unreservedly employed to represent the scenes and transactions of the invisible one. That is, after the devout mind has been accustomed in detail to associations of that kind, comes in the most comprehensive phrase that could be employed, apparently confirming, by the Creator's authority, the view of creation, thus become familiar. Perbaps it adds something to the argument, 
that in the second instance the phrase occurs within a few sentences of the conclusion of the whole Bible.

(7.) Nominalists however of various classes are ready enough with their solutions of these appearances. They say, "it is the imperfection of language; the Almignty Himself condescending to employ human words and idioms, could no otherwise convey ideas of the spiritual world, than by images and terms taken from objects of sense." Or again, "it is the genius of Orientalism: if GoD vouchsafed to address the men of any particular time or country, he would adopt the modes of speech suited to that time and country." Or "the whole is mere poetical ornament, the vehicle of moral or historical truth, framed to be beautified and engaging in its kind, in mere indulgence to the infirmity of human nature."

But as to the particular point in question, would it not be enough to say, in auswer to all these statements together, that even if granted in fact, they fail as explanations? since the question would immediately occur, Who made Language, or Orientalism, or Poetry, what they respectively are? Was it not One, who knew beforehand that $\mathrm{He}$ should adopt them one day, as the channel and conveyance of $\mathrm{His}$ truth and His will to mankind ? Surely, reason and piety teach us, that Gon's providence prepared language in general, and especially the languages of Holy Scripture, and the human styles of its several writers, as fit media through which His supernatural glories and dealings might be discerned : and if they be so formed as necessarily to give us notions of a certain correspondence between the supernatural and the visible, we can hardly help concluding that such notions were intended to be formed by us; except there be some direct text, or strong analogy of faith, against it.

(8.) It is not very easy to see what is gained by the very rigorous mode of interpretation, which some would apply to the phraseology of the Bible. Illustrations, they say, and analogies, are never to be pressed a hair's breadth further than the least which the context itself, and the turn of the reasoning or sentiment, makes absolutely necessary. We must never be contented till we bave exhausted them, as nearly as possible, of all superna. 
\$ vii. 9. tural meaning: just as the same people count it an axiom, that in historical narratives there must be as few miracles, and in Church ceremonies as few sacraments, as may be.

These rules hardly approve themselves to natural piety, which is ever anxious to trace GoD as near at hand as it can, alike in His words and in His works. Neither do they well agrce with the manner in which the Old Testament is commented on in the New, nor with the sort of expansion and development in detail, which subsequent passages not seldom furnish, of an idea only just thrown out at first. In short, it seems equally absurd to say, on the one hand, that the minimum of mystical sense is always to be preferred, as it would be on the other, always to be trying to extract as much of it as ever we can :-equally absurd, and perhaps not quite so reverential. Surely it will always be a question of degree, not so much how far each sensible image has some spiritual meaning, as how far we are able to extract that meaning with any sort of certainty or satisfaction; saving, as was just now said, the analogy of faith and the truth of other Scriptures. Certainly there is no very obvious reason why we should incline to the defect, rather than the excess in this matter.

(9.) Waving, however, these remarks, which would seem to render all attempts of the kind nugatory, let us see how the Bible imagery will accommodate itself to the particular theories above mentioned, of those who would resolve it into mere accidents of language. First, if the whole were mere necessity, arising out of the imperfection of human speech ; or if it were oriental boldness of phrase, or poetical ornament; the symbols would probably be more varied than we find them to be: the same external object would not so constantly occur, to express the same invisible thing, through so large a collection of compositions, so widely differing in style and tone. As to the imperfection of human speech, we all feel every hour how it causes us to modify and alter our images: we take the best symbol which occurs at the time, but we use it in a kind of restless unsatisfied way, like persons aware that it is not simply the best; and by the time we need it again, we have lighted very likely on something far truer 
and more vivid : and thus, we go on in conversation or in writing, " $\$$ vii. 10. improving or marring our imagery, as the case may be, but still letting it be felt that it is by no means fixed and unchangeable.

Again, as to poetical ornament, variety and versatility of resource is obviously a great ingredient of that sort of excellency : to be always resorting to the same similitude or analogy would rather of course betray want of skill or power.

The third solution, that of Orientalism, may seem at first sight to be more satisfactory as to this particular circumstance, of the same figure constantly repeated. Granting, however, that the literature of the Eastern nations is in some respects, like their manners, more fixed and monotonous than ours, and accordingly, that it uses to express things out of sight by a certain uniform imagery, suggesting the notion of a settled and understood allegory : yet in the first place, we know not how far this literature may have been originally modelled on the Hebrew Scriptures, instead of their taking any tone from some previous form of it, the very existence of which, after all, is but conjectural. Next, such a statement would put in a stronger light the fact of that kind of style having been adopted by the HoLy GHost, whereby its symbolical words would seem to be raised to the rank of Divine Hieroglyphics, so to call them. And thirdly, except we suppose such a foundation of truth in them, it seems hard to explain the sanction given to them by the writers of the New Testament, using as they did a language, and applying themselves (St. Paul and St. Luke especially) to a condition of literature and society, well nigh the opposites of what this theory supposes to have existed in Asia and the East.

The fixedness therefore of the Scriptural Imagery does not appear to be sufficiently accounted for by any criticism of this kind: but it is accounted for, if we suppose the material world originally constructed with a view to the sacred analogies which this symbolical alphabet of Scripture (if we may so denominate it) suggests.

(10.) But here an objection occurs, of no small moment. The fact may perhaps be denied, that the symbols of Scripture are so fixed and regular, as this part of our argument supposes. And the authority of St. Augustin may be appealed to, who scems to lay 
§ vii. 10. down a rule at first sight inconsistent with it. "Because," says he ${ }^{1}$, "there are a variety of ways in which one thing may appear to resemble another, we are not to imagine it a set-rule, "Whatsoever in any one place any thing has stood for in the way of simile, that we are always to account its signification.' For the image of leaven has been employed by the Lorv Himself, both in the way of reproof, as when He said, 'Beware of the leaven of the Pharisees,' and in the way of praise, when He said, 'The Kingdom of Heaven is like unto a woman which hid leaven, in three measures of meal, until the whole was leavened "."

And then he proceeds to point out that this variety of symbolical meaning may be in all degrees. "The same thing may sometimes stand for contraries, here in a good sense, there in a positively bad one, as in the instance just mentioned of leaven; or again, as the lion is the emblem of CHrist ; 'The lion of the Tribe of Judah hath prevailed :' and it is the emblem also of the Devil; 'He goeth about as a roaring lion, seeking whom he may devour:' so the serpent, now in a good sense; 'Be ye wise as serpents ;' and now in a bad one; 'The serpent beguiled Eve through his subtilty:-Bread, in a good sense; 'I am the living Bread, which came down from Heaven ;' and in a bad one, 'Bread eaten in secret is pleasant.' And there are many other such.

"Now of these which I have mentioned, the signification is not doubtful : because, our object being to exemplify, none but clear cases could properly be introduced. But there are also some whereof it is doubtful what turn we ought to give them : as, 'In the hand of the Lond there is a cup of pure wine, full mixed.' For here it is doubtful, whether he means the anger of God, stopping short of the last penalty, i. e. not exhausted quite to the dregs ; or rather, the grace of the Scriptures passing from Jews to Gentiles, expressing by Inclinavit ex hoc in hoc: 'He hath stooped it. away from this side, and entirely towards that :' there remaining with the Jews only the outward observances, whereof they have but a carnal understanding: and to this purpose may be, 'The dregs thereof are not emptied.' 
"But thirdly," proceeds St. Augustin, "the same thing is \$ vii. 11 . sometimes spoken of not absolutely in contrary, but only in diverse meanings; as water signifying both the people:-as we read in the Apocalypse, 'The waters where the whore sitteth are peoples, and multitudes, and nations, and tongues :' and the Holy SpIrit ; whence is that saying, 'Out of his belly shall flow rivers of living water:' and so there may be other things here and there, whereof water is understood to be the emblem, according to the context of the places where it occurs."

Thus far St. Augustin: but when his instances come to be examined, it will be found perhaps that his differences of signification may be all reduced to different shades or aspects of the same meaning. The Leaven, whether it be bad or good, equally represents moral impressions silently communicated from one to another: the Lion represents a royal warrior, the Serpent, one who counsels deeply and craftily, be their nature and their cause what it may: Bread is that which satisfies the cravings of the soul, in its healthy or in its diseased state: Wine in Goo's Hand (the allusion is too sacred to be expressed without fear and hesitation,) may, consistently with the rest of Holy Scripture, be interpreted of the highest and most mysterious of all privileges, which is either life or death as men choose to receive it. Of water in its several meanings we shall speak presently.

(11.) But now, if the expression of different objects by the same symbol, which St. Augustin thus largely illustrates, is reconcileable with the general uniformity of the scriptural imagery, much more the converse of it; I mean when the same object is represented by different symbols. 'To take the highest and most obvious, and also the most frequent example: our Lord CHRist in His several offices and relations may be represented by symbols as different from each other as a Lamb and a Lion, the Sun in Heaven and a Vine among trees, a Serpent of brass or a Stone cut out of a mountain: and yet no violence be done to the harmony (so to call it) of the symbolical language: not only because things positively unlike may answer well enough to each other in the way of analogy, and so may represent Him in some one of His relations; but also because it is reasonable to think, 


\section{St. Augustin on manifold Meanings in one Scripture :}

$\S$ vii. 12. that the whole creation can hardly be too large or too various to shadow out His manifold aspects, who is all in all to every one of His creatures.

In the greatest possible variety, whether of objects typified by one symbol, or of symbols typifying the same object, there must still be substantial uniformity, because all point or converge towards Him, His work and His everlasting kingdom: just as all languages, however unlike in sound and structure, must be made up virtually of the same parts of speech, having to express the same mental processes, and the same external world.

(12.) With regard then to both grounds of scruple, we may thankfully acquiesce in the practical rule of St. Augustin 1. "When from the same words of Holy Writ not one single meaning, but two or more occur to our minds; though we know not what was in the mind of him who wrote the words, there is no danger, if it can be shown from other passages of the Holy Scriptures that either one of these senses is in harmony with the truth; provided always that the person engaged in searching out the Divine Words make this his object, to come at the meaning of the author, by whose agency the How Ghost wrought out this Scripture. Either this, I say, he must attain, or he must frame some other meaning out of those words, not opposed to the right faith, providing himself with authority from some other portion of God's Word. For possibly the author himself saw the same meaning in the passage we wish to explain; and certainly, at least, the SPIRIT of God, who by him composed those words, foresaw that it would occur to the reader or hearer; nay, $\mathrm{He}$ took care that it should occur, seeing that it also, by hypothesis, rests on the truth. For what larger or more abundant provision could have been made by Divine care in the authoritative words of GoD, than for the same words to be capable of more acceptations than one, other sayings no less Divine testifying to the same, and demanding our approbation for them?"

Thus far St. Augustin; and it seems well worth consideration, whether there be not somewhat in the ordinary experience of

1 De Doct. Chr. iii.38. 
us all, to confirm his view, high and transcendental as it §vii. 13 is. Consider how very differently the same words sound in our ears, according to our different moods of mind; how much more meaning we find, not only in a text of Scripture, but in a chance passage of a book or a stray remark of a friend, when we recall it by and by, more seriously than at first we listened to it ; nay, and how much beyond what we suspected we discover occasionally in our own words, uttered perhaps at first by instinct, we hardly knew how : so that not only are we always uncertain whether any two persons receive exactly the same impression - the same moral impression, that is, - from any given words, but even whether to the same person the same ideas are conveyed by them twice. And yet there is truth and definite meaning in the words so spoken, although they go so mucb deeper with one man than they do with another. Surely then it ought not to seem strange that the words of the Mosr $\mathrm{H}_{\text {IGH, }}$ spoken with full knowledge of the thoughts of all who should read or hear them, should be intended to give out more or less of signification according to our preparation of heart; and that, in that sense, their meanings should be even infinite in number and variety. It is only the fact which our own experience suggests, applied to the case of those sayings which are inspired.

Again; we know well that our good and serious moods are those in which we most surpass ourselves in our apprehension of deep and grave sayings; and what is this in effect, but St. Augustin's remark, "That practice strengthened by the exercise of piety-usus pietatis exercitatione roboratus-will greatly aid us in coming to a true signification?" Well is it for those, who are able to confirm this, from the help which they have found in pure imaginations, and rightly tuned affections, rather than contrariwise, from the hindrance they have brought on themselves by indulging base and frivolous fancies. But in one way or the other, we must all more or less have experienced it.

(13.) Further, one may conceive a person arguing, that this view is dangerous and apt to unsettle foundations, making all doctrines subjective rather than objective; true to the individual, not true vol. vi, -89. 


\section{The Creeds guard the Allegory against doctrinal Abuse.}

\$ vii. 13. in themselves. There is obviously danger of this; but here too the experience we have appealed to will help us. Great as the interval may be between one man and another in their understanding of a given passage, - or between our own ordinary perception of it, and that which we enjoy when our thoughts are most elevated and refined,-yet these variations are all within certain limits: the imagery tends all in the same general direction, though some go never so much deeper, higher, wider, than others : just as we do not question the real significancy of words, or the existence of coloured objects, because we are not sure that the shades of meaning or of colour are quite the same to any two different minds. The Catholic Faith, the Mind of Crrist testified by His universal Church, limits the range of symbolical interpretation both in Scripture and in nature: the Protestant watchword, Verbum Dei, must be made primitive by the constant addition, Verbum Deus : or, as St. Augustin again expresses it, "We that are made the Body of Christ, let us not fail to recognise our own voice in the Psalms and other Scriptures :" our own voice, because it is the Voice of Him in whom we are all made one. "Christ," he proceeds, "wheresoever in those Books, wheresoever in those Scriptures I am journeying and panting for breath, in that sweat of our face which is part of our sentence as men,-CHrist is there, openly or secretly to meet and refresh me. It is He Himself, who, by the very difficulty which I sometimes have in finding Him, inflames my longing, so that what I do find of His I may eagerly suck in, and retain to my soul's health, absorbed in my very joints and marrow." And," "In reading the Scriptures, he only, who finds no pleasure in these holy manifestations of CHRIST, is turned unto fables, not enduring sound doctrine." In other words, the analogy of faith, CHRIsT set before us in the Creeds of the Church, will give a fixedness and reality to our symbolical interpretations, how wide soever in other respects the latitude and variety which seems to be allowed in thern.

It need only just be mentioned that the apparent double or manifold senses of a great portion of the Prophecies, and the 
manner in which the New Testament generally accommodates, §vii. 14. as it is called, texts from the Old, obviously harmonize with what has been advanced out of St. Augustin on this head.

(14.) Closely connected with this topic, of the fixedness of the sacred symbols, is what may be called their complexity; the manner in which, not seldom, the primary and simple ones among them are varied and combined, as letters are combined into syllables, words, and sentences, retaining each somewhat of their original sound : or rather, as those compound derivatives which are made up of significant terms, each term modified, not changed, in its import. To take an example, than which none can be more holy and venerable, none, as it may seem, more unquestionable. The appropriate symbol of the Holy SpIrit is, as the name implies, Breath-the Breath of the FATHER and the Son, omnipresent, all powerful: and hence it is sometimes represented by the air or wind, as in our Lond's well known words to Nicodemus, and when the disciples on the day of Pentecost heard a sudden sound as of a rushing mighty wind; and His function as the Lord and Giver of Life is represented by the gift of respiration to living things. "GoD breathed into man's nostrils the breath of life, and man became a living soul ;" and "when He letteth His breath go forth, they are made; and He reneweth the face of the earth."

But breath has not only in it air, but moisture ; and this condensed is first clouds, then drops of rain, then water gushing out in springs, or flowing in rivers; or in a way of approach yet more silent and invisible, dew: and all these are scriptural emblems of the HoLY Spirit in Its several aspects and relations. The overshadowing and guiding cloud, in which as well as in the Red Sea, the Israelites were baptized unto Moses, was a token, we know from St. Paul, of the descent of the regenerating SPIRIT of $\mathrm{CHRIST}$, with a hovering, brooding motion, like that of a dove, first on our Lond Himself, then on each of His Members at their baptism : its appearing over the 'Tabernacle in glory, and filling both it and the Temple, prefigured the warmth and brightness of the heavenly Comforter, diffusing Itself over the whole Church at once, and entering into every 
\$ vii. 14. corner of the new-born soul : the descent of a cloud in rain or dew, is the Srrrit communicating Himself in gifts and sanctifying graces; becoming (if one may so speak,) water for the nourishment of our souls, as $\mathrm{He}$ was air to give them life ; according to that verse in the Psalm, " Thou, O Lord, sentest a gracious rain upon 'Thine inheritance, and refreshedst it when it was weary :" and it may be that the express words of the HoLy GHost are compared to distinct drops of rain, and His silent promptings to the dews, more aërial and impalpable. So Moses, "My doctrine," my set and formal instructions, "shall drop as the rain; my speech," my incidental hints and whispers, "shall distil as the dew."

The fountains again and depths of pure water, gushing out for our purification and refreshment, how or from whence we know not, except that we are sure they are originally derived from above,-these are the Holy Ghost in His larger communications of baptismal, sacramental grace; opening fountains in the hard dry heart of man, which seem to belong to it, but are entirely the gatherings of His rain. And this image is kept up even to the final description of the Church's glory; where, as it should seem, the goings forth of the Comforter are typified by " a pure river of water of life, proceeding out of the throne of GoD and of the Lamb," with the Tree of Life growing beside it for the healing and quickening of the nations. And indeed all that is said in every part of the Scriptures, concerning the righteous as trees of the Lond's planting, the Church as His vineyard, the wicked as corrupt and wild plants, -in itself one of the plainest and most abundant of all the sources of scriptural parables, - combines wonderfully well with the thought of air and water, as emblems of the life-giving, sanctifying Breath of the Most High.

On the other hand, as the Breath of GoD thus becomes water, to cherish, and refresh, and cleanse those souls which have not forfeited the Divine Life, so in It's severer influences, either to purify or consume, (for purgation is partial consuming,) It becomes fire from heaven: first to try, and prove, and refine, every man's work here; next, utterly to destroy and 
waste what shall be found vile and refuse hereafter. Thus $\mathrm{He} \S$ vii. 15 . who is a consuming fire, and who had so shewn Himself on Mount Sinai, and on so many other occasions when the ungodly were to perish at $\mathrm{His}$ presence; $\mathrm{Hz}$ made His coming known by cloven tongues like as of fire, when that flame was to be kindled which Christ came to send upon the earth: and we have an awful notice given, that it is "the Breath of the Lond," which "as a stream of brimstone, kindles" the fire which is "ordained of old" and "prepared for the devil and his angels."

Thus remarkably does the one idea of the Breath of the Lord, followed up and variously combined with others, explain almost all the principal symbols used in Scripture to denote the influences and operations of the HoLy SpIrit of God. Surely the Ancient Church was justified in thinking that analogies, so uniformly kept up, and at the same time so elaborate and complex, were intended for something beyond mere poetical ornament. When, with hearts and memories full of Scripture, they looked out on Nature and her operations, they could not but be conscious that the lessons which they had read and heard were perpetually coming before them in what they saw: and how was it possible for them to help believing that the association was providential and divine; they who were accustomed to behold GoD's hand in far lesser and more ordinary things?

(15.) Besides, they found this kind of correspondence repeatedly taken for granted and reasoned on in the Holy Scripture itself. Did they not see how St. Paul works out in the minutest detail the notion of the Church being the Body of Christ? how he teaches us to deduce from it our every day duties and relations to each other? And could they doubt that all this was intended, in the first formation of the human body, by Him who caused all things to be for the Church's sake? In these analogies unfolued by St. Paul, and still more strikingly in our Lond's Parables, they would perceive the principle sanctioned, and the means afforded, of spiritualizing all the chief objects and processes of which common life, and the world of sense, are made up: and they would think themselves justified in reverently carrying on these analogies, according to their skill, to other points of detail, not expressly mentioned in Scripture. 
§.vii. 15. As an example, take St. Augustin's comment on all exquisite pastoral image in the Song of Solomon. He is not, observe, reasoning in proof of our principle, - that was always taken for granted by the Fathers, - but he is descanting on the beauty and usefulness of it. "Why," he asks ', " is the hearer less delighted, when he is told literally of holy and perfect men, whose life and conduct are the means, whereby CHRist's Church separates those who come to her from all superstitions, and unites them, imitating the good which they see, to her own body, which same good and faithful and true servants of GoD have cast off the burthens of the world, and have drawn near to the Holy Laver of Baptism, and going up from thence, are now, through the quickening SpIRIt, bearing the fruit of both kinds of love, the love of God and of our neighbour:-why is it, I say, that the literal statement of these things affords less satisfaction to the hearer, than if one expound to the same effect that verse in the Song of Songs, where it is said to the Church, receiving praise under the similitude of a beautiful woman, " Thy teeth are like a flock of sheep even shorn, which are gone up from the washing, which every one of them bear twins, and there is none barren among them ?' Certainly the instruction one receives is in substance no more, than in listening to the former statement, made as it was in the most literal words, without the support of this similitude. And yet there is, I know not how, an additional pleasure in contemplating those saints, when I see them, quasi dentes Ecclesia, cutting off men from their native errors, and transferring them in a manner into the substance of her body, divided into morsels, and champed, and their hardness mollified. Again, I recognise with great delight the sheep newly shorn, their earthly burthens, as fleeces, deposited, and going up from the bath, i. e., from baptism. I see how they all bring forth twins, the two commandments, namely, of love; and not one of them is barren of that boly fruit."

This, it will be observed, is produced by St. Augustin himself as a specimen of the mode of interpretation, which the Church in his time received undoubtingly, as the true mind of the 
SPIRIT : and whatever may be thought of the particular instance, $\S$ vii. 16, 17 . many will feel that there is both piety and probability in such a mode of using the riches of Scripture and of Nature, mutually to illustrate and bring out each other; and will see in this eager profuse way of heaping simile upon simile, something not unlike St. Paul's own manner of passing rapidly, even in the gravest arguments, from one analogy to another more or less connected with it: as from the seed changed in the ground to the difference between earthly bodies and heavenly ; and again, from the unequal magnitude of the stars to the inequality of the Saints in glory. There is no discrepancy between the tone of the Apostles and that of the Church in after ages, in respect of their both assuming, clearly and deliberately, a certain correspondence, intended by the $C_{R E A T O R}$, between the material and spiritual worlds.

(16.) Something perhaps is added to this argument by the manner in which our Lord's own example teaches us to take up and use proverbial sayings. "Lift up your eyes and look unto the fields, for they are white a'ready unto the harvest ;" "If they do these things in a green tree, what shall be done in the dry?" By instructing $\mathrm{His}$ disciples to affix a divine sense, an interpretation connected with the things of His kingdom, to familiar household words such as these, He seems to sanction the idea, that there is perhaps nothing so low and trivial in our ordinary life, but a spiritual and heavenly meaning may be found for it. And further, He seems to hint to us, that this correspondence of things seen with unseen, is by no means so ligh and transcendental a matter, but that it may well be set before the minds even of very simple uneducated Christians-the class which is most apt to be attracted by proverbs, and to use them frequently.

(17.) Another, and a yet more direct sanction appears to be afforded by the large use of material signs for spiritual objects and processes in the inspired Mosaic Ritual. The whole of that Ritual served, we know, to the example and sbadow of heavenly things; it was made and ordered according to the pattern shewed to Moses in the Mount. Here, therefore, were no inconsiderable number of visible materials, forms, and actions, concerning 
\$ vii. 18,19. which the Fathers knew for certain that they were intended to express heavenly things, - that their archetypes, so to speak, existed in the Mount. By reference to these they might prove and check, as it were, the conclusions to which they had come in other ways, whether by instinct, or obscure tradition, or examination of scriptural imagery in general, regarding the symbolical meaning of external objects. If they had been led, for example, to conjecture that certain animals - the lamb, the dove, the ox, the goat, and the like-were types, or tokens, in nature, of certain spiritual beings or truths : they would be confirmed in such their conjecture by the use of those animals, or their images, in the worship and furniture of the Tabernacle. The like may be said of plants-the palm, the cedar, the hyssop, and others; of colours, such as white, purple, and scarlet ; of materials, linen and woollen; metals and precious stones : the use of any such thing in the divinely ordained ritual would give a new and heavenly significance to any mention of it which might occur in Isaiah and the Psalms, and both together would set it apart for ever, in the judgment of affectionate and imaginative minds, as a natural symbol or sacrament of something out of sight.

(18.) The historical Scriptures too would often furnish additional presumptions to the same effect, by the recorded use of certain materials and forms, - the material of wood for instance, and the form of the Cross, - in God's miraculous and providential dealings. Indeed, so many and so clear are the correspondencies in this kind, that there have not been wanting ingenious writers, both in ancient and modern times, who have explained particular parts, both of the ritual and history, such as the forms of the Tabernacle and Temple, and the construction of the Ark, as physical allegories, designed to represent the system of the world, or the frame of the human body : theories seemingly too wild and strange to be maintained by men of learning and piety, but accounted for, if we may be allowed to suppose that both the history or ritual on the one hand, and the system of the world or of the body on the other, are separate sets of visible symbols shadowing out invisible truths.

(19.)There is one way more, and a very obvious one, in which 
the consideration of the Ritual and History might confirm the early $\S$ vii. 20. Christians in their mystical explanations of the whole external world. They found some particulars, both ritual and historical, mystically expounded in the New Testament, and plain implications, almost assertions, that the whole was capable of similar exposition: $e$. g. that "Moses made all things according to the pattern shewed him in the Mount;" and that "all that befel God's people in the wilderness happened unto them as types of us." When therefore in the natural world they had ascertained a few chief symbols, it was reasonable for them to infer that these too were but specimens, single chords of a harmony to be fully made out hereafter: they would feel like learners of a language, who have picked up the meaning as yet but of a few words here and there, but have no doubt whatever that the whole has its meaning: and perhaps they would think that they found warrant for this in such texts as that of St. Paul to the Romans, "The invisible things of Him from the creation of the world are clearly seen, being understood by the things that are made." This would seem to lay down the principle or canon of mystical interpretation for the works of Nature, as the other texts, just now specified, for the Mosaic ceremonies and the history of the Jews.

(20.) So much for the direct encouragement given in the Bible to the symbolical use of things natural. There is, as was mentioned above, another indirect yet real presumption to the same effect, which at present can only just be adverted to: and that is, the studied preference of poetical forms of thought and language, as the channel of supernatural knowledge to mankind. Poetry, traced as high up as we can go, may almost seem to be GoD's gift from the beginning, vouchsafed to us for this very purpose : at any rate the fact is unquestionable, that it was the ordained vehicle of revelation, until God Himself was made manifest in the flesh. And since the characteristic tendency of poetical minds is to make the world of sense, from beginning to end, symbolical of the absent and unseer, any instance of divine favour shewn to Poetry, any divine use of it in the training of God's people, voL. v1. -89 . 
186 Favour shewn to Poetry, an indirect Sanction to Mysticism.

§ vii. 20. would seem, as far as it goes, to warrant that tendency; to set GoD's seal upon it, and witness it as reasonable and true.

Much might be said on this head: but it is enough now to have just indicated it, as one among the many reasons for thinking that Christian Antiquity was far more scriptural, than at first we might be apt to imagine, as in many other things, so in the deep mystical import, which it unreservedly attributes to the whole material world, and to all parts of it.

(To be continued.)

These Tracts are continued in Numbers, and sold at the price of $2 d$. for each sheet, or $7 s$. for 50 copies.

LONDON : PRINTED FOR J. G. F. \& J. RIVINGTON, ST. PAUL'S CHURCH YARD, AND WATERLOO PLACE. 1841. 
The following Works, all in single volumes, or pamphlets, and recently published, will be found more or less to uphold or elucidate the general doctrines inculcated in these Tracts:-

Bp. Taylor on Repentance, by Hale.-Rivingtons.

Bp. Taylor's Golden Grove.-Parker, Oxford.

- Vincentii Lirinensis Commonitorium, with translation.-Parker, Oxford.

Pusey on Cathedrals and Clerical Education.-Roake \& Varty.

Hook's University Sermons.-Talboys, Oxford.

- Pusey on Baptism (published separately).-Rivingtons.

- Newman's Sermons, 4 vols.-Rivingtons.

Newman on Romanism, \&c.-Rivingtons.

- The Christian Year.-Parker, Oxford.

- Lyra Apostolica.-Rivingtons.

Perceval on the Roman Schism.-Leslie.

Bishop Jebb's Pastoral Instructions.-Duncan.

Dodsworth's Lectures on the Church.-Burns.

Cary on the Apostolical Succession.-Rivingtons.

+. Newman on Suffragan Bishops. - Rivingtons.

+ Keble's Sermon on National Apostasy. - Rivingtons.

- Keble's Sermon on Tradition.-Rivingtons.

Memoir of Ambrose Bonwick.-Parker, Oxford.

Hymns for Children on the Lord's Prayer.-Rivingtons.

Law's first and second Letters to Hoadly-Rivingtons.

- Bp. Andrews' Devotions. Latin and Greek.-Pickering.

Hook's Family Prayers. - Rivingtons.

- Herbert's Poems and Country Pastor.

Evans's Scripture Biography-Rivingtons.

Le Bas' Life of Archbishop Laud.-Rivingtons.

Jones (of Nayland) on the Church.

Bp. Bethell on Baptismal Regeneration.-Rivingtons.

Bp. Beveridge's Sermons on the Ministry and Ordinances.Parker, Oxford.

Bp. Jolly on the Eucharist.

Fulford's Sermons on the Ministry, \&c.-Rivingtons. 
At a Mceting of the Vice-Chancellor, Heads of Houses, and Proctors, in the Delegates' Rooni, Mareh 15, 1841 -

Considering that it is enjoined in the Statutes of this $\mathrm{Zni-}$ versity (Tit.' III.'Sect. 2, 'Tit. IX. Sect. II. \$, 3, Sect. V. \$. 3) that every Student shall be instructed and exanined in the Thirty-nine Articles, and shall subscribe to them; considering

$\mathrm{R}$ also that a Tract has recently appeared, dated from Oxford, and entitled "Remarks on certain passages in the Thivty-nine

A Articles", being No. 90 of the 'Tracts for the Times, a series of anonymoas publications purporting to be written by Meinbers of the University, but which are in no way sanetioned by

P. the University itself;

Resolved, That modes of interpretation such as are sug-

S1 gested in the said Tract, evading rather than explaining the sense of the Thirty-nine Articles and reconeiling subseription. to thein with the adoption of errors, which they were designed to connteract, defeat the object, and are inconsistent with the due observance of the above-mentioned Statutes.

Bi Upon the appearance of the above, the following letter was put iu immediate circulation :-

T Mr. Vice-Chancellor,-I write this respectfully to inform

P. you, that I am the anthor, and have the sole responsibility, of the Tract on which the Hebdomadal Board has just now. expressed an opinion, and that I have not given my name hitherto, under the belief that it was desired that I should not. I hope it will not surprise you if I say, that my opinion remains unchanged of the truth and lionesty of the principle maintained in the Tract, and of the necessity of putting it

B forth. At the same time I am prompted by my feelings to

add my deep conseiousness that every thing I attempt minht

$B$ be done in a better spirit, and in a better way; and, whilo I

WV am sincerely sorry for the trouble and anxiety I have given to the Members of the Board, I bog to return my thaniss to theun

W for an act, which, even though founded on misappieliension, may be made as profitable to myself as it is religiously and P. may be macle as prot

L. I say all this with great sincerity; and am,

L. Mr. Vice-Chancellor, your ubedient servnt,

B Oriel College, March 16th, 1841. John Hevry Nrwints.

P)

Palmer on the Church.-Rivingtons.

Hooker, ed. Keble.-Rivingtons. 


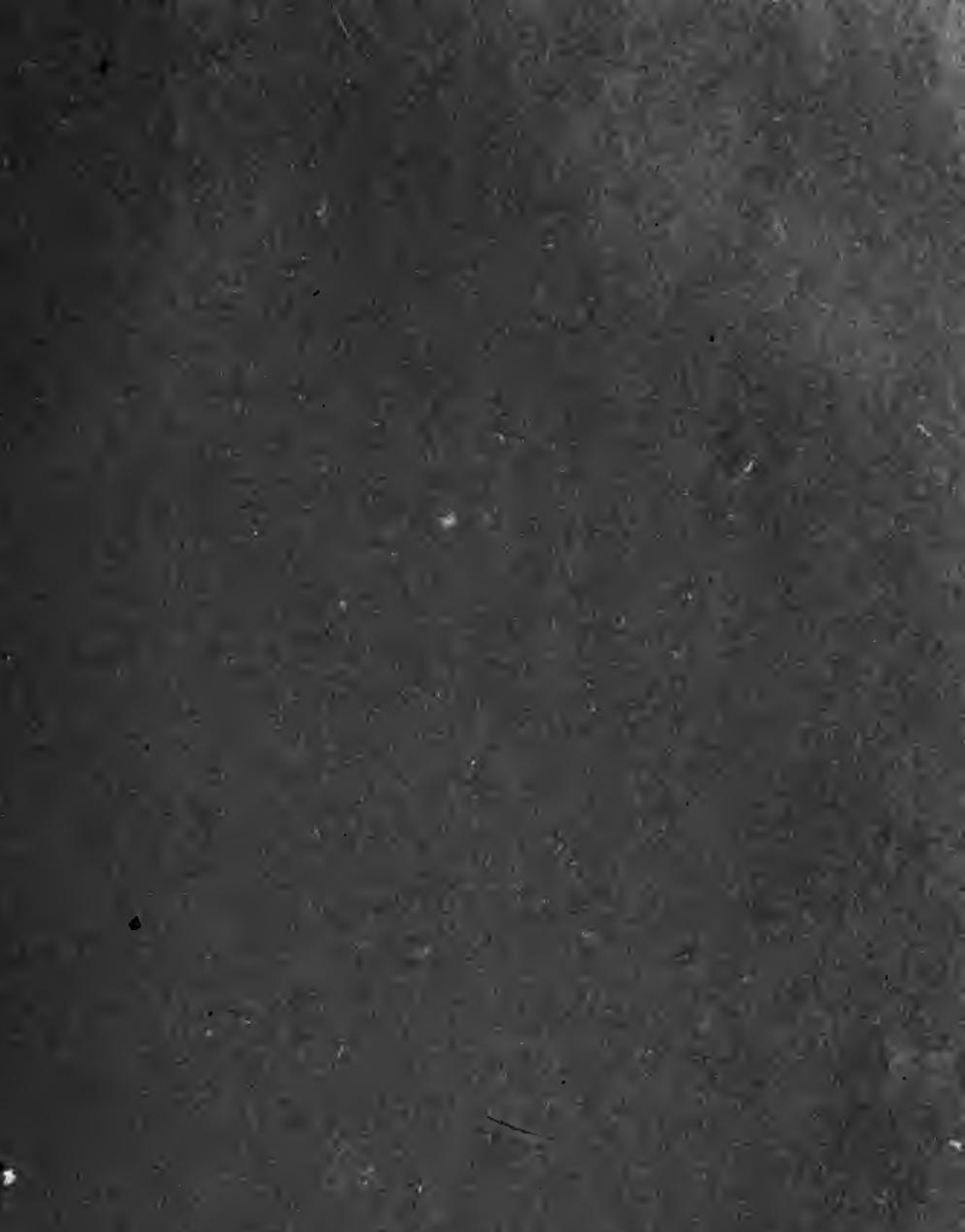

v 
